ADILSON JOSÉ MANGETTI

Desenvolvimento histomorfológico do trato digestório de larvas de pintado Pseudoplatystoma coruscans

(Agassiz, 1829)

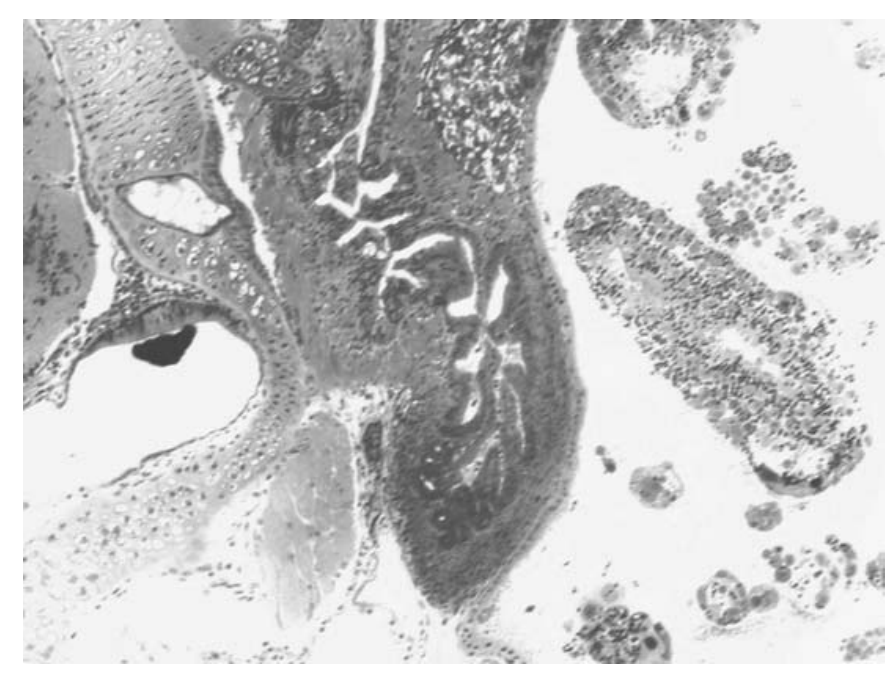

São Paulo

2006 


\section{Desenvolvimento histomorfológico do trato digestório de larvas de pintado Pseudoplatystoma coruscans Agassiz, 1829}

Dissertação apresentada ao Programa de Pósgraduação em Anatomia dos Animais Domésticos e Silvestres da Faculdade de Medicina Veterinária e Zootecnia da Universidade de São Paulo para obtenção do título de Mestre em Ciências

\section{Departamento:}

Cirurgia

Área de concentração:

Anatomia dos Animais Domésticos e Silvestres

\section{Orientador:}

Prof. Dr. Francisco Javier Hernandez-Blazquez

São Paulo 
Autorizo a reprodução parcial ou total desta obra, para fins acadêmicos, desde que citada a fonte.

\section{DADOS INTERNACIONAIS DE CATALOGAÇÃO-NA-PUBLICAÇÃO}

(Biblioteca Virginie Buff D’Ápice da Faculdade de Medicina Veterinária e Zootecnia da Universidade de São Paulo)

T.1709 Mangetti, Adilson José

FMVZ Desenvolvimento histomorfológico do trato digestório de larvas de pintado Pseudoplatystoma coruscans Agassiz, 1829 / Adilson José Mangetti. - São Paulo: A. J. Mangetti, 2006.

94 f. : il.

Dissertação (mestrado) - Universidade de São Paulo. Faculdade de Medicina Veterinária e Zootecnia. Departamento de Cirurgia, 2006.

Programa de Pós-graduação: Anatomia dos Animais Domésticos e Silvestres.

Área de concentração: Anatomia dos Animais Domésticos e Silvestres.

Orientador: Prof. Dr. Francisco Javier Hernandez-Blazquez.

1. Histologia. 2. Trato digestório. 3. Estômago. 4. Surubim pintado. 5. Larva. I. Título. 


\section{UNIVERSIDADE DE SAOO PAULO \\ Faculdade de Medicina Veterinaria e Zootecnia \\ Assistência Acadêmica \\ PARECER}

Interessado: Adilson José Mangetti

Assunto: Protocolo de experimentação adotado em experimento animal.

A Comissão de Bioética da Faculdade de Medicina Veterinária e Zootecnia da Universidade de São Paulo, após analisar o projeto sob o número 766/2005, intitulado: "Desenvolvimento histomorfológico do trato digestório de larvas de surubim pintado Pseudoplatystoma coruscans", utilizando 70 larvas de surubim pintado, sob responsabilidade da Prof. Dr. Francisco Javier Hernandez Blazquez, constatou que o mesmo foi realizado de acordo com os princípios de bioética, adotados por esta Comissão.

São Paulo, 06 de outubro de 2005

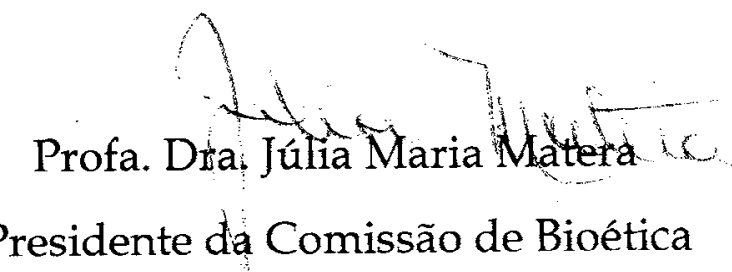

FMVZ/USP 


\section{FOLHA DE AVALIAÇÃO}

Nome: MANGETTI, Adilson José

Título: Desenvolvimento histomorfológico do trato digestório de larvas de pintado Pseudoplatystoma coruscans Agassiz, 1829

Dissertação apresentada ao Programa de Pósgraduação em Anatomia dos Animais Domésticos e Silvestres da Faculdade de Medicina Veterinária e Zootecnia da Universidade de São Paulo para obtenção do título de Mestre em Ciências

Data:

1

Banca Examinadora

Prof. Dr. Instituição:

Assinatura: Julgamento:

Prof. Dr. Instituição:

Assinatura: Julgamento:

Prof. Dr. Instituição:

Assinatura: Julgamento: 


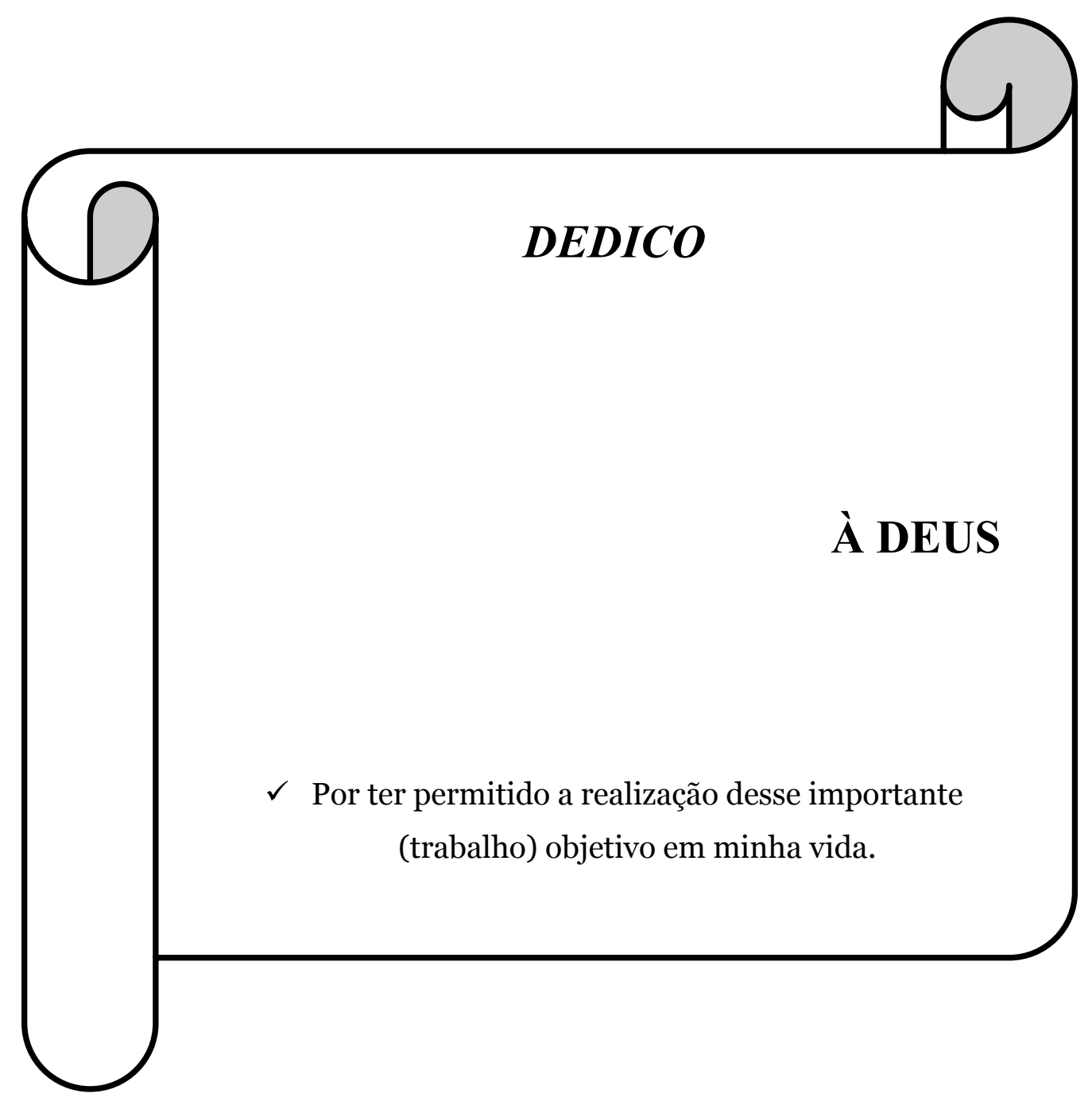




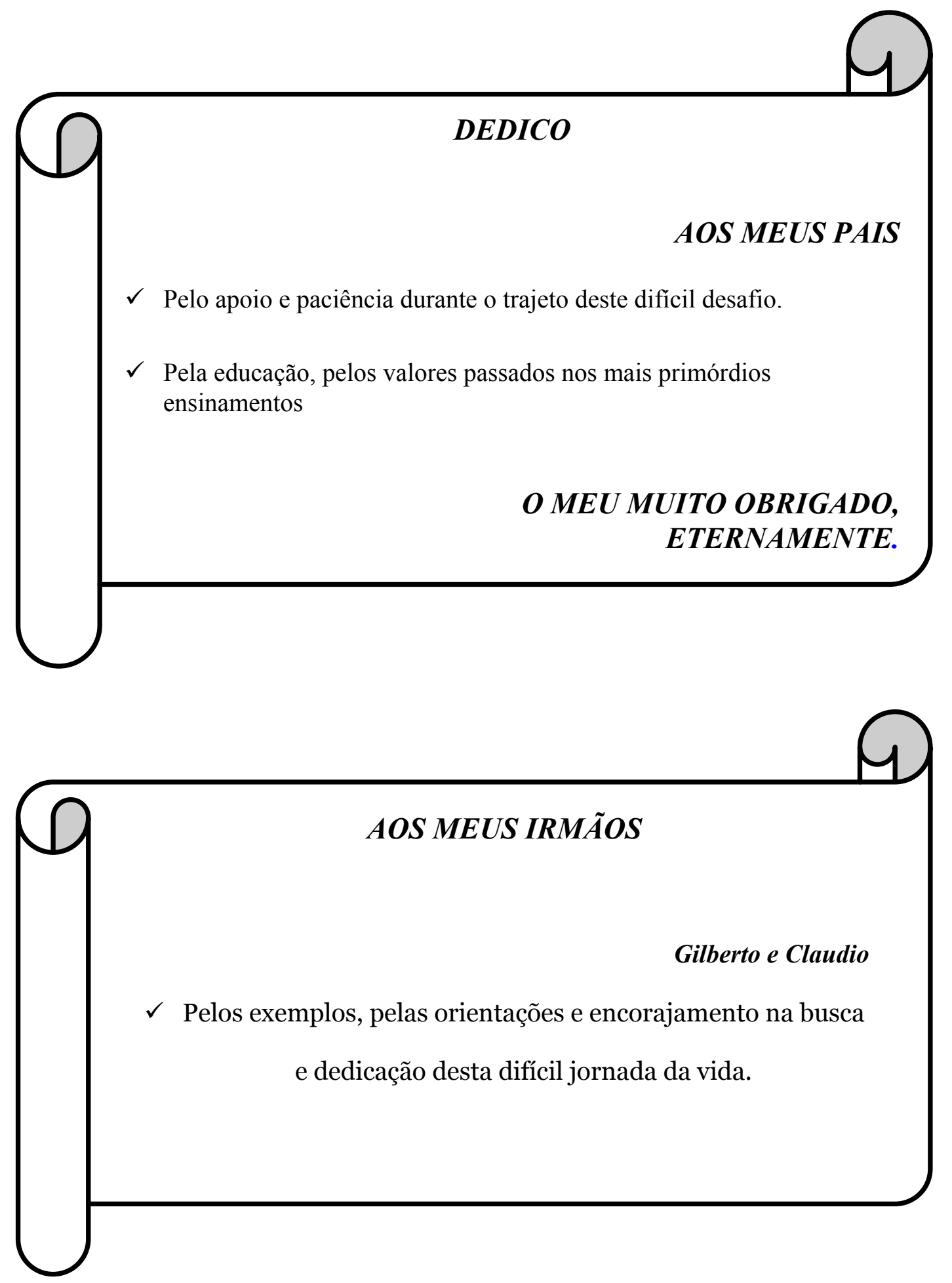




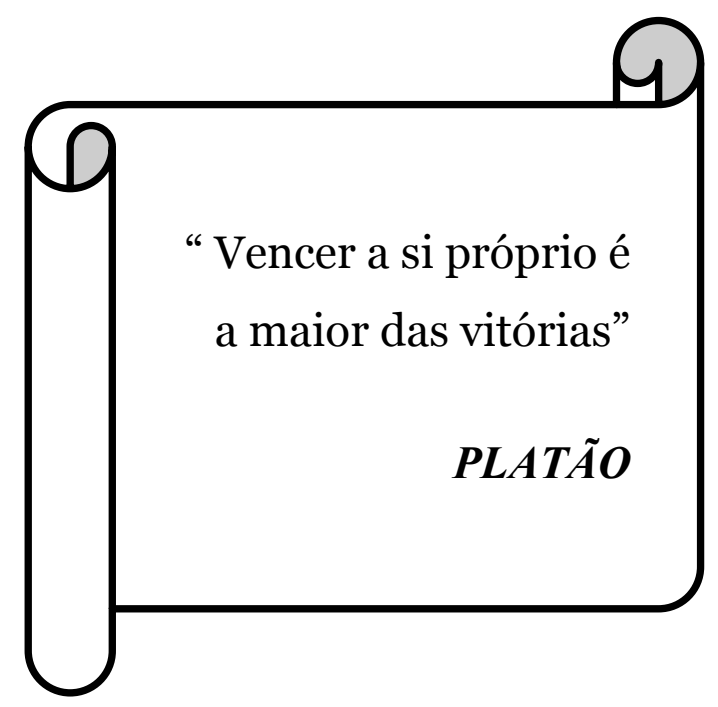




\section{AGRADECIMENTOS}

Ao Prof. Dr. ${ }^{\circ}$ Francisco Javier Hernadez Blazquez, pelo grande incentivo em todos os momentos que mais precisei neste trabalho, por ter acreditado, pela confiança, orientação e por ter me iniciado no campo da pesquisa confiando em meu potencial de trabalho.

Aos Pesquisadores Marcos Antonio Cestarolli e Fernando Andre Salles que gentilmente me receberam no Instituto de Pesca no Distrito de Cachoeira de Emas no Município de Pirassununga - SP e forneceram as amostras de larvas (material) utilizados no experimento e também na ajuda da redação da trabalho.

Ao Prof. Dr. ${ }^{0}$ Flávio Vieira Meirelles e a Prof. Dr ${ }^{\mathrm{a}}$ Claudia Lima Verde Leal pelo incentivo e oportunidade concedida abrindo as portas do Laboratório de Biologia Molecular e de Histologia da FZEA - Pirassununga, necessário para realização das técnicas histológicas.

A todos os Professores do Curso de Pós-Graduação da FMVZ de São Paulo, pelos conhecimentos transmitidos, formação científica e pela disposição e prontos a nos ajudar.

Ao Nilton Pedro dos Santos, técnico do Laboratório de Biologia Celular e de Histologia da FZEA - Pirassununga, pela amizade, ajuda, cooperação e suporte técnico.

Aos funcionários da biblioteca da FZEA de Pirassununga, Patrícia Fernadez Vick Rosa, Maria Osória Andrade Teixeira, Cláudio Fernando Germano Ramos, Marcelo Roberto Dozena, Bernardete Aparecida Brunelli Mehleer, Iara Amorim, pelo constante apoio e auxilio imprescindíveis na elaboração desta dissertação.

Aos funcionários da Secretaria do Departamento de Anatomia Maicon Barbosa da Silva e Jaqueline Martins de Santana.

As funcionárias da Secretaria da Pós-Graduação da FMVZ Deyse Maria Alves Flexa e Claudia Lima. 
Aos funcionários do Departamento de Anatomia: Edinaldo Farias (Índio), Diogo Palermo,

Raimundo Leal de Sousa e João do Carmo Freitas, pela convivência descontraída, pelos conhecimentos transmitidos e os "galhos quebrados".

Aos funcionários da Biblioteca da FMVZ.

$\checkmark$ À Faculdade de Medicina Veterinária e Zootecnica da Universidade de São Paulo.

Aos colegas do curso de Pós-Graduação, pelo convívio, aprendizagem, compreensão e pelos diversos momentos agradáveis.

$\checkmark$ As técnicas Giovana Krempel e Sandra Aparecida de Oliveira da FZEA - Pirassununga pela amizade e descontração.

$\checkmark$ As minhas cunhadas Adélia Guerra Mangetti, pelo exemplo de vida e as considerações prestadas e à Alessandra Rebolças, por ter me recebido gentilmente em seu apartamento durante o qual me serviu de família no período como aluno regular no curso.

$\checkmark$ À Aline Sinotti D’Avilla, que apareceu, encorajando-me e apoiando-me com palavras positivas.

$\checkmark$ À FAPESP, pelo apoio financeiro sem o qual a realização do presente estudo não teria sido possível. 


\section{RESUMO}

MANGETTI, A. J. Desenvolvimento histomorfológico do trato digestório de larvas de pintado, Pseudoplatystoma coruscans, Agassiz, 1829. [Development histomorfological of the digetório tract in surubim pintado Pseudoplatystoma coruscans Agassiz, 1829 larvae]. 2006. 94 f. Dissertação (Mestrado em Ciências) - Faculdade de Medicina Veterinária e Zootecnia, Universidade de São Paulo, São Paulo, 2006.

A carne do bagre pintado neotropical é muito apreciada e apresenta grande potencial comercial no mercado de peixe brasileiro. Embora o conhecimento do desenvolvimento inicial do trato digestório de larvas de pintado seja muito importante para a estratégia de produção da criação de peixes, há pouca informação sobre este assunto. Neste trabalho estudamos as modificações estruturais e funcionais do trato digestório do pintado entre o $3^{\circ} \mathrm{e}$ o $16^{\circ}$ dia após a eclosão. As lâminas histológicas foram coradas para estudar a morfologia e a secreção ácida e neutra do trato digestório do pintado. $\mathrm{O}$ alimento foi encontrado no intestino a partir do $3^{\circ}$ após a eclosão. As células que secretam muco ácido e neutro foram observadas no esôfago e seu número aumentou com idade. O estômago estava revestido com epitélio de secreção ácida e neutra. Do $11^{\circ}$ dia após a eclosão para frente, glândulas gástricas tubulares com células oxintopépticas granular formam identificadas na mucosa do estômago. Neste momento a fração neutra do muco epitelial aumentou e sua fração ácida foi reduzida. No $13^{\circ}$ após a eclosão o muco foi exclusivamente neutro. $\mathrm{O}$ segmento proximal do intestino no $3^{\circ}$ dia após eclosão da larva estava anteriormente dilatado, formando a bolsa intestinal. A bolsa é revestida por enterócitos e células caliciformes que produzem muco ácido e neutro. $\mathrm{O}$ tamanho da bolsa intestinal diminui com o tempo e é grandemente reduzida no $16^{\circ} \mathrm{DPE}$. Notou-se que a partir do $11^{\circ}$ DPE o segmento intestinal distal é enovelado e a mucosa formam várias pregas revestidas de enterócitos e células caliciformes que secretam muco neutro ou ácido. Um curto segmento retal foi observado. A larva de pintado ingere alimento no início do $3^{\circ} \mathrm{DPE}$, mas seu trato digestório somente parece estar completamente preparado para 
eficientemente processar o alimento no estômago, após o surgimento das glândulas gástricas no $13^{\circ} \mathrm{DPE}$, quando este órgão desenvolve as características do estômago químico.

Palavras-chave: Histologia. Trato digestório. Estômago. Surubim pintado. Larva. 


\begin{abstract}
MANGETTI, A. J. Development histomorfological of the digetório tract in surubim pintado Pseudoplatystoma coruscans Agassiz, 1829 larvae. [Desenvolvimento histomorfológico do trato digestório de larvas de pintado Pseudoplatystoma coruscans Agassiz, 1829]. 2006. 94 f. Dissertação (Mestrado em Ciências) - Faculdade de Medicina Veterinária e Zootecnia, Universidade de São Paulo, São Paulo, 2006.
\end{abstract}

The meat of the neotropical spotted catfish ("surubim pintado", Pseudoplatystoma coruscans) is very appreciated and shows great commercial potential in Brazilian fish market. Although the initial development of the pintado larvae digestive system is very important to the production strategies of fish farms, there is little information about this subject. Here, we studied the structural and functional modifications of the digestive tract of pintado Pseudoplatystoma coruscans larvae between $3^{\text {rd }}$ and $16^{\text {rd }}$ days after hatching (DAH). Histological slides of larvae were stained by toluidine blue, Alcian blue and Schiff reactiveperiodic acid (PAS) stains in order to study the morphology and the acidic and neutral mucins secretion, respectively. Food was found in the gut after $3^{\text {rd }}$ DAH. Mucous cells secreting acidic and neutral mucins were observed in the esophagus and their number increased with age. The stomach was lined by a mucus secreting epithelium with acidic and neutral mucins. From 11 DAH onward, tubular gastric glands with granular oxyntopeptic cells were identified in the stomach mucosa. At this time the neutral fraction of the epithelial mucins increased and their acidic fraction was reduced. At $13 \mathrm{DAH}$ the mucins were exclusively neutral. The proximal segment of $3^{\text {rd }}$ DAH larvae intestine forms an anterior swelling, the intestinal bulb. It is lined by enterocytes and goblet cells that produces acidic and neutral mucins. The size of the intestinal bulb decreases with time and is greatly reduced by the $16^{\text {rd }} \mathrm{DAH}$. The distal intestinal segment is coiled and its mucosa forms several folds lined by enterocytes and goblet cells which secretes either neutral or acidic mucins. A short rectal segment is observed. The pintado larvae ingest food as early as the $3^{\text {rd }} \mathrm{DAH}$, but its digestive system only appears to be 
fully prepared to efficiently process the food in the stomach after the gastric glands arise at the $13^{\text {rd }}$ DAH, when this organ develops the histological features of a chemical stomach.

Key words: Histology. Digestive system. Stomach. Surubim pintado. Larvae. 


\section{LISTA DE ABREVIATURAS E SIGLAS}

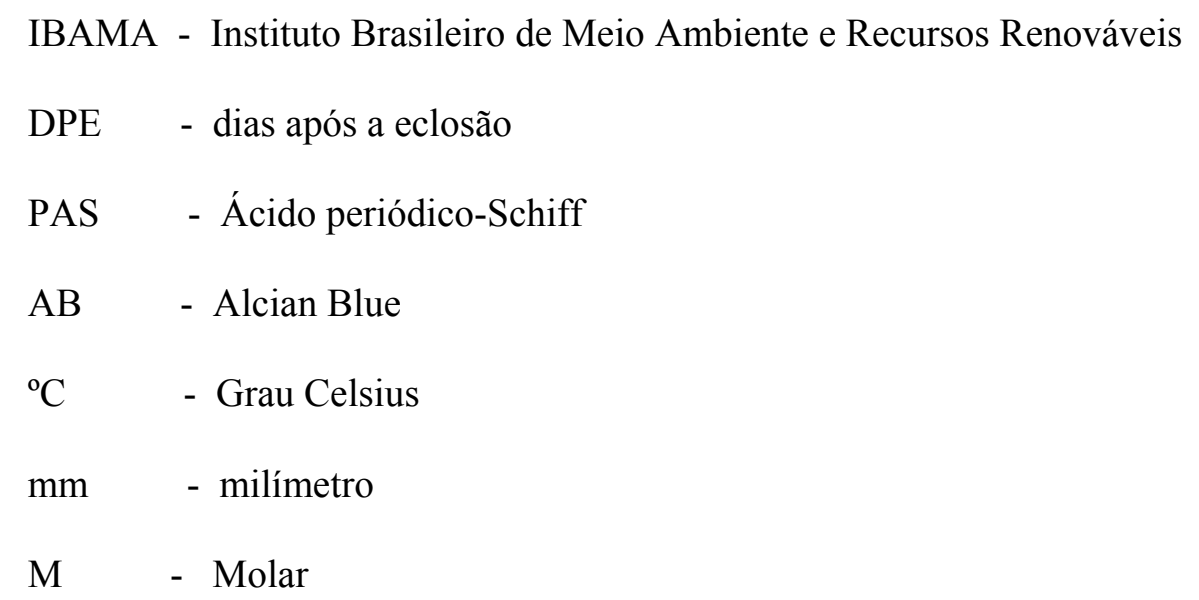




\section{LISTA DE TABELAS}

Tabela 1 Vista lateral esquerda da larvas de Pseudoplatystoma coruscans, onde pode ser vista ventralmente a saliência da bolsa intestinal. A- larvas com 13 DPE e em B- larvas com 11DPE. Barra=

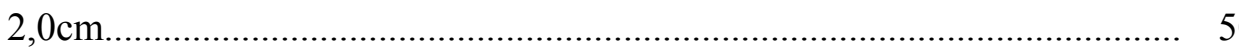

Tabela 2 Intensidade da coloração das células mucossecretoras para o PAS (muco neutro) e Alcian Blue (muco ácido) no esôfago e estômago de larvas de Pseudoplatystoma coruscans. 


\section{LISTA DE FIGURAS}

Figura 1 - Vista lateral esquerda de larvas de Pseudoplatystoma coruscans, onde pode ser vista ventralmente a saliência da bolsa duodenal. A- larvas com 13 DPE e em B- larvas com 11

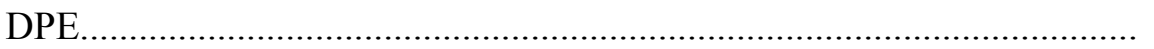

Figura 2 - Fotomicrografia ilustrando corte sagital da larva de Pseudoplatystoma coruscans com 5 DPE mostrando região do esôfago com células mucosas (seta curta), primórdio do estômago (seta longa), bolsa intestinal (bi) repleta de alimentos (Artemia nauplii) situada na região ventral do abdome e parte do intestino intestino proximal (ip). Azul de toluidina.Barra $=0.4 \mathrm{~mm}$

Figura 3 - Fotomicrografias em corte sagital da larva de Pseudoplatystoma coruscans ilustrando a região de transição entre o esôfago e o primórdio do estômago. A - Larvas no $5^{\circ}$ DPE evidenciando reação positiva ao $\mathrm{AB}$. Barra $=50 \mu \mathrm{m}$. B - Larvas no $5^{\circ} \mathrm{DPE}$ evidenciando reação positiva ao PAS. Barra $=50 \mu \mathrm{m}$. C - Larvas no $9^{\circ} \mathrm{DPE}$ evidenciando reação positiva ao AB. Barra $=50 \mu \mathrm{m}$. D - Larvas no $9^{\circ} \mathrm{DPE}$ evidenciando reação positiva ao PAS. Barra $=50 \mu \mathrm{m}$. Observar na região do esôfago (es) a presença de muitas células mucosas $(\longrightarrow)$ com aspecto barril e citoplasma repleto de grânulos de secreção. Observar a camada muscular (cm) no esôfago, e no primórdio do estômago (pes) o epitélio prismático simples com núcleo na região basal. Parte da bolsa intestinal (bi) com alimentos (Artemia nauplii)

Figura 4 - Fotomicrografias ilustrando corte sagital do estômago da larva de Psedoplatystoma coruscans. A - Larvas no $11^{\circ} \mathrm{DPE}$ evidenciando reação positiva ao $\mathrm{AB}$. Barra $=100 \mu \mathrm{m}$. B - Larvas no $11^{\circ} \mathrm{DPE}$ evidenciando reação positiva ao PAS. Barra $=100 \mu \mathrm{m}$. C - Larvas no $16^{\circ} \mathrm{DPE}$ evidenciando reação negativa ao Alcian blue $\mathrm{pH} 2,5$. Barra $=$ $100 \mu \mathrm{m}$. D - Larvas no $16^{\circ} \mathrm{DPE}$ evidenciando reação positiva ao PAS. Barra $=100 \mu \mathrm{m}$. Luz do estômago (est), camada muscular $(\mathbf{c m})$ e região de glândulas gástricas (gg). No primórdio do estômago (pes) pode-se observar o epitélio prismático simples com núcleo na região basal.

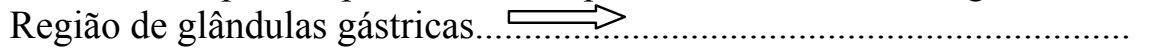

Figura 5 - A- Fotomicrografia ilustrando trato digestório de larvas de Pseudoplatystoma coruscans corada com azul de toluidina. A - Corte sagital em larvas com 7 DPE mostrando esôfago (es), primórdio do estômago ( $\longrightarrow$ ) e bolsa intestinal (bi) situada na região ventral do abdome repleta de alimentos (Artemia nauplii) e também o intestino proximal (ip). O reto é a região onde a ponta de seta indica. Barra $=0.4$ mm. B - Larvas no $5^{\circ} \mathrm{DPE}$ mostrando a região do esôfago com muitas células mucosas (seta vasada) e primórdio do estômago formado por epitélio colunar onde o muco acumulado sobre a região apical do 
citoplasma aparece escuro (seta aponta) e parte da bolsa duodenal. Azul de toluidina. Barra $=30 \mu \mathrm{m}$. C - As vesículas nos enterócitos (ponta da seta) provavelmente são gotas de lipídeos em larvas com 9 DPE. Barra= $30 \mu \mathrm{m}$. D - Epitélio cúbico baixo (ponta da seta) da bolsa duodenal. Barra $=30 \mu \mathrm{m}$.

Figura 6 - A- Fotomicrografia ilustrando em corte sagital o trato digestório da larva de Pseudoplatystoma coruscans. A - Esôfago (es) e estômago em larvas no $11^{\circ} \mathrm{DPE}$ onde podem ser observadas as primeiras glândulas gástricas (ponta da seta). Barra $=100 \mu \mathrm{m}$. B - Intestino proximal (ip) e intestino distal (id) em larvas no $13^{\circ} \mathrm{DPE}$ observar a organização das pregas intestinais. $\mathrm{O}$ epitélio do intestino distal é mais escuro e menos vacuolizado do que o intestino proximal. Barra $=50 \mu \mathrm{m}$. C - Estômago da larva com 13 DPE. Nesta fotomicrografia, as barras mostram a transição entre as criptas (esquerda) e glândulas gástricas (direita). $\mathrm{O}$ citoplasma das células oxintopépticas contém grânulos de secreção (ponta da seta). Barra $=20 \mu \mathrm{m}$. D - Estômago da larva no $16^{\circ} \mathrm{DPE}$. Barra $=50 \mu \mathrm{m}$. As criptas (c) e glândulas (g) estão bem definidas. Abaixo das glândulas pode ser observada duas túnicas musculares.

Figura 7 - Fotomicrografias ilustrando em corte sagital do intestino da larva de $P$. coruscans no $11^{\circ}$ DPE. A - Segmento proximal do intestino. Epitélio cilíndrico absortivo com enterócitos (ent) mostrando borda estriada (be) bem desenvolvida e citoplasma repleto de vesículas supra e infranucleares (vsi). Azul de toluidina. Barra $=50 \mu \mathrm{m}$. B - Outra região do intestino proximal mostrando célula caliciforme $(\mathbf{C c})$ no topo da prega evidenciando muco ácido. Observar núcleo na região basal da célula. Azul de toluidina. Barra $=50 \mu \mathrm{m}$. C - Enterócitos (ent) na região dorsal da bolsa intestinal. Observar borda estriada (be) e o epitélio com forma cúbico baixa. Azul de toluidina. Barra $=50 \mu \mathrm{m}$. D - Célula caliciforme (Cc) no fundo da cripta (cr) no intestino distal, evidenciando reação positiva ao PAS. Luz (lu) Barra= $50 \mu \mathrm{m}$

Figrua 8 - Fotomicrografias ilustrando intestino da larva de $P$. coruscans. A- Corte sagital das pregas em uma região do intestino proximal (ip)e do intestino distal (id), em larvas no $7^{\circ} \mathrm{DPE}$. B- Corte sagital mostrando destalhes das pregas (prg) no intestino distal em larvas com $7^{\circ}$ DPE. Observar tecido conjuntivo frouxo (tcf) $\mathrm{C}$ - Corte transversal da região do intestino distal de larvas no $11^{\circ} \mathrm{DPE}$, mostrando pregas intestinais (pre) e células caliciformes (Cc), evidenciando reação positiva ao Alcian Blue. D - Corte transversal da região do intestino distal em larvas no $11^{\circ} \mathrm{DPE}$ mostrando pregas intestinais e células caliciformes evidenciando reação positiva ao PAS. Luz (lu). Barra=

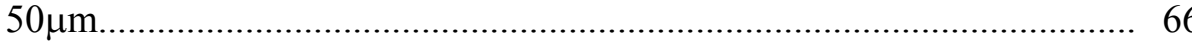




\section{SUMÁRIO}

1 INTRODUÇÃO

2 OBJETIVOS

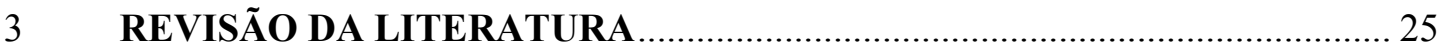

3.1 Sistemática do Pseudoplatystoma coruscans Agassiz.......................................... 25

3.2 Descrição da espécie Pseudoplatystoma coruscans ................................................ 26

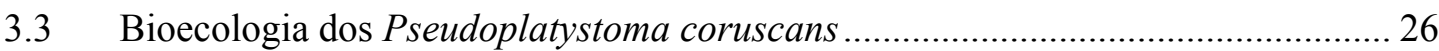

3.4 Fatores ambientais e a extinção do Pseudoplatystoma coruscans........................... 27

3.5 A importância econômica da criação do Pseudoplatystoma coruscans ................... 29

3.6 Hábitos alimentares e estruturação do trato digestório dos peixes ........................... 31

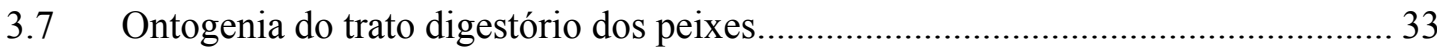

4 ESÔFAGO

5 ESTÔMAGO

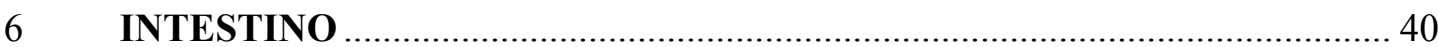

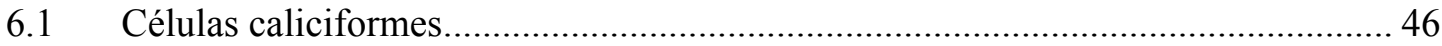

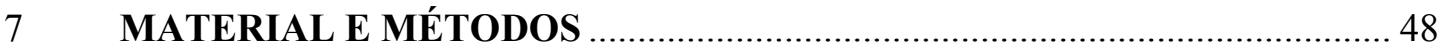

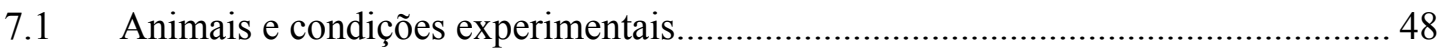

7.2 Colheita, fixação e processamento para microscopia óptica .................................. 49 


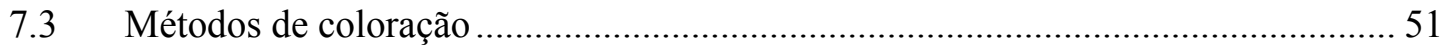

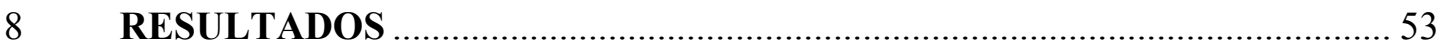

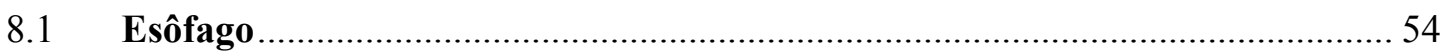

8.1.1 Mucosa

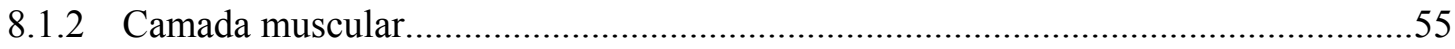

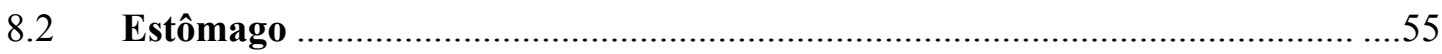

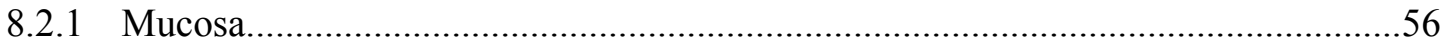

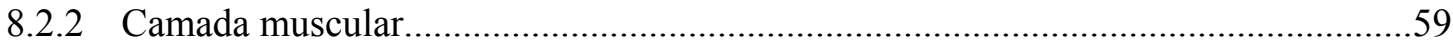

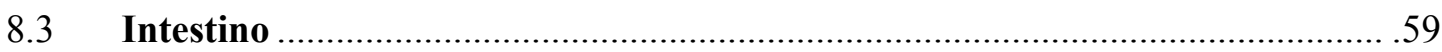

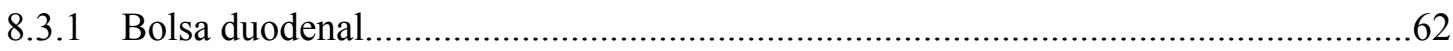

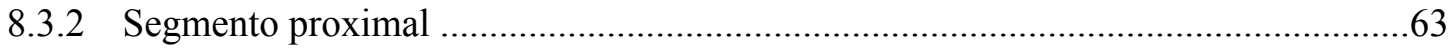

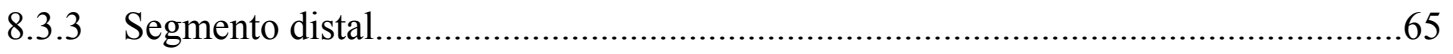

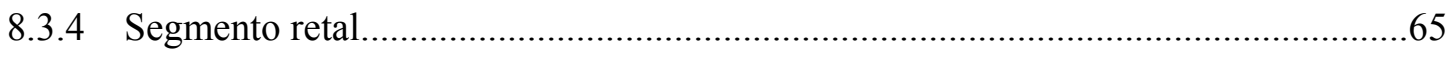

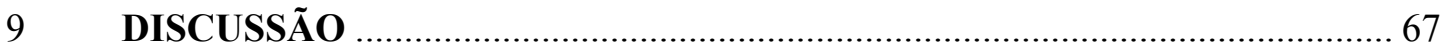

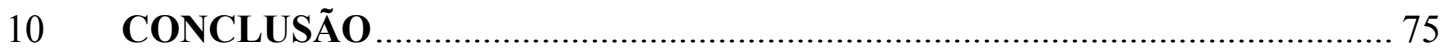

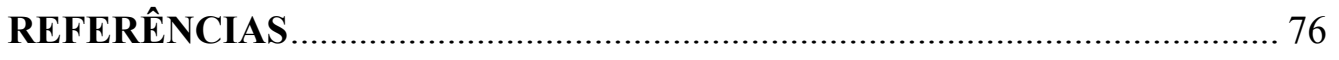




\section{INTRODUÇÃO}

O pescado, como fonte de proteína, apresenta no Brasil um potencial ainda não muito explorado, consequentemente a produção é pouco significativa, com baixo consumo, isto, considerando o extenso litoral, a abundância de águas continentais, a biodiversidade de espécies de peixe e o clima favorável.

No Brasil, a piscicultura é desenvolvida majoritariamente em água doce. A piscicultura de água doce tem como característica uma grande diversidade de espécies. Aproximadamente 50 espécies em diferentes níveis de cultivo vêm sendo utilizadas na aqüicultura brasileira . A produção total de peixes em cativeiro, somando 132.989 toneladas, era em grande parte proveniente do cultivo de carpas e tilápias. Essas espécies somavam 54.567 e 32.460 toneladas, respectivamente (HILSDORF; MOREIRA, 2004).

O gênero Pseudoplatystoma, conhecido como bagres neotropicais, estão entre as espécies mais apreciadas na pesca de água doce, devido ao seu porte e à qualidade da carne, com grande aceitação pelo consumidor brasileiro. Dentre eles destaca-se o pintado Pseudoplatystoma coruscans, espécie encontrada nas bacias hidrográficas do Prata e do São Francisco (BRITSKI; SATO; ROSA, 1988).

O pintado, por apresentar grande importância econômica, é objeto de vários estudos com o intuito de viabilizar sua produção em cativeiro e preservação da espécie. Uma das dificuldades na criação da espécie Pseudoplatystoma coruscans, é o manejo alimentar, em virtude do canibalismo e da sua inabilidade em aceitar, de imediato, rações convencionais (KUBITZA, 1995).

Bons índices zootécnicos credenciam o pintado como uma espécie de excelente potencial comercial (MIRANDA, 1993). Para o sucesso da criação racional de uma espécie é essencial o conhecimento dos hábitos alimentares e das características morfofisiológicas do 
sistema digestório em especial nas fases de larvicultura e alevinagem, etapas muito importantes a serem otimizadas.

O desenvolvimento inicial e o regime alimentar nos primeiros dias de vida dos peixes criados intensivamente são críticos para a produção de alevinos (PINTO, 1984). Para (SORGELOOS et al., 1991) a alimentação nos estágios larvais iniciais dos peixes, é um dos pontos cruciais na piscicultura. Estudos vêm sendo realizados com o objetivo de aprimorar dietas artificiais quem promovam o crescimento e a sobrevivência das larvas de peixes equivalentes àquelas obtidas com alimentos vivos. Contudo, a maioria das espécies de larvas apresenta um canal alimentar simples e indiferenciado, desenvolvendo mais tarde os órgãos digestórios (GOVONI; BOEHLERT; WATANABE, 1986). Para os mesmos autores, as mudanças nas estruturas do trato digestório, que ocorrem durante o desenvolvimento caracterizam diferentes adaptações funcionais a dietas e concentrações de presas. Dabrowski (1984), explica que ao longo do desenvolvimento larval, ocorrem mudanças nos processos de digestão, absorção e assimilação de compostos químicos.

A larvicultura das espécies de peixes com potencial para a piscicultura constitui um dos sérios obstáculos ao desenvolvimento da atividade, sendo a alimentação das larvas considerada um dos principais fatores críticos para sobrevivência e crescimento das mesmas (GEIGER, 1983; GEISER, et al., 1985). Desta forma, conhecer as mudanças ocorridas no desenvolvimento do trato digestório, associado ao processo de absorção de nutrientes, é essencial para o entendimento da físiologia da nutrição de larvas de peixes (SEGNER et al., 1993), uma vez que a administração precoce de dietas artificiais sem o trato digestório estar preparado, pode causar alta mortandade das larvas e grandes perdas econômicas (LOPES, et al., 1996). Nesse sentido, o estudo da morfologia e do desenvolvimento do sistema digestório, auxilia na compreensão dos processos alimentares e no planejamento de dietas adequadas para larvas e alevinos. Estudando o desenvolvimento larval de Prochilodus scrofa, 
(CAVICCHIOLI; LEONHARDT, 1993), notaram transformações na morfologia intestinal. As análises do conteúdo e morfologia intestinais permitiram sugerir uma mudança de habitat e hábito alimentar entre os estágios larvais de flexão e pós-flexão da coluna vertebral.

Estudos sobre a morfologia e a histologia do trato digestório de alevinos e adultos de pintado descrevem-no como um peixe carnívoro que possui esôfago, estômago e intestino bem diferenciados. A mucosa do esôfago de animais adultos de Pseudoplatystoma coruscans, é constituída por numerosas pregas primárias longitudinais, entremeadas de pregas secundárias, recobertas por uma camada epitelial pavimentosa, com predominância de mucopolissacarídeos ácidos (SOARES, 1993). Em alevinos, essa mesma camada não é queratinizada, constituída por células mucosas que reagem ao mucopolissacarídeo neutro, e células claviformes, em menor número que as anteriores (SOUZA, 1999).

Tanto em adultos como em alevinos o estômago está presente, e sua mucosa se apresenta pregueada, contendo células epiteliais colunares com mucopolissacarídeos neutros na porção apical. As glândulas existentes na mucosa gástrica classificam-se como tubulares simples. Essas glândulas contêm células denominadas de oxintopépticas, que estão envolvidas na secreção de ácido clorídrico, tendo atividade pepsinogênica (SOARES, 1993; SOUZA; 1999).

A região proximal do intestino é revestida por epitélio prismático simples - os enterócitos - e células caliciformes. As células absortivas apresentam mucopolissacarídeos neutros em sua superfície. Há poucas células caliciformes com mucopolissacarídeos ácidos e neutros (SOARES, 1993). Anatomicamente o intestino distal difere do proximal por apresentar pregas longitudinais, maior grau de pregueamento da mucosa e borda estriada menos espessa (SOARES, 1993; SOUZA, 1999). Este último autor constatou ainda uma distribuição abundante de células caliciformes no epitélio. 
Embora haja descrições sobre a morfologia do trato digestório de alevinos e adultos de pintado, não há estudos sobre o desenvolvimento anatômico e histológico do trato digestório dessa espécie durante a fase larval, antes ou próximo do momento da transição da dieta de animais vivos para a ração, ou seja para a dieta artificial.

Neste trabalho estudou-se o desenvolvimento do trato digestório do pintado desde a eclosão até o $16^{\circ}$ dia de vida pós-eclosão, procurando avaliar os aspectos anatômicos e histológicos de cada segmento do trato e relacioná- los com o processo de digestão, em função da idade do animal. 


\section{OBJETIVOS}

- Acompanhar o desenvolvimento histológico dos órgãos do trato digestório e descrever suas modificações estruturais em larvas de pintado desde o $3^{\circ}$ dia da eclosão, até o $16^{\circ}$ dia de vida.

- Verificar as modificações histoquímicas do muco secretado pelas células epiteliais do trato digestório de larvas de pintado durante seu crescimento. 


\section{REVISÃO DA LITERATURA}

O surubim, também conhecido como pintado encontra-se na ordem dos Siluriformes na sistemática, o qual também é classificado como peixes de couro. A principal característica externa é a ausência de escamas sobre o corpo, sendo revestido apenas de pele espessa, ou coberto, parcial ou totalmente, com placas ósseas (SANTOS, 1981). Apresentam barbilhões, em geral um par maxilar e dois pares mentonianos e, freqüentemente, o primeiro raio da nadadeira dorsal e das peitorais se constitui de um acúleo forte e pungente (BRITSKI; SATO; ROSA, 1988).

3.1 Sistemática do Pseudoplatystoma coruscans, segundo (LAUDER; LIEM, 1983):

Super Classe: Pisces

Classe: Osteichthyes

Subclasse: Actinopterygii

Ordem: Siluriformes

Subordem: Siluroidei

Família: Pimelodidae

Gênero: Pseudoplatystoma Bleeker, 1862

Espécie: Pseudoplatystoma coruscans (Agassiz, 1829)

A subordem Siluroidei compreende treze famílias na região neotropical, das quais sete ocorrem no rio São Francisco. Uma delas, a família Pimelodidae, compreende formas muito diversificadas, algumas diminutas com poucos centímetros e outras gigantes com mais de dois metros de comprimento, que não apresentam escamas, aberturas branquiais amplas e, freqüentemente, nadadeiras dorsais e peitorais precedidas por um acúleo (BRITSKI; SATO; ROSA, 1988). 


\subsection{Descrição da espécie Pseudoplatystoma coruscans}

As espécies do gênero Pseudoplatystoma apresentam como aspecto morfológico o corpo alongado e roliço, com cabeça deprimida e largura ao nível da boca apenas ligeiramente menor do que a largura total do corpo, mandíbula mais curta que a maxila superior e dentes viliformes no palato.

O pintado Pseudoplatystoma coruscans em particular, apresenta relações morfométricas em que o comprimento total varia de 5,5 a 7,1 vezes a altura total e de 2,6 a 3,0 vezes o comprimento da cabeça. Seu flanco e dorso apresentam máculas arredondadas e suas nadadeiras dorsal e caudal manchas menores (BRITSKI; SATO; ROSA, 1988; MIRANDA, 1993).

O pintado é a espécie que atinge o maior porte entre os peixes da bacia do São Francisco, podendo alcançar de $100 \mathrm{~kg}$ até $120 \mathrm{~kg}$ e por apresentar em sua carne poucas espinhas, é um dos peixes preferidos nos restaurantes, (SATO et al., 1988b).

\subsection{Bioecologia do Pseudoplatystoma coruscans}

O Pseudoplatystoma coruscans, é um peixe de água doce, de hábitos noturnos, que se alimenta principalmente de outros peixes menores sendo classificado, portanto, como carnívoro e piscívoro devido a seus hábitos migratórios, aparece em grande quantidade temporariamente, sendo os machos mais freqüentes no mês de março, e as fêmeas em abril no rio Paraná entre outros locais (CORDIVIOLA, 1966).

Os pimelodídeos são também ecologicamente os mais diversificados, incluindo desde grandes predadores como os do gênero Brachyplatystoma (piraíba, piramutaba) e Pseudoplatystoma (surubim, cachara) que se alimentam de presas inteiras, até o Calophysus 
macropterus capaz de rasgar pedaços de peixes e alguns omnívoros como os Pimelodus que se alimentam de peixes e insetos (GOULDING, 1980; MARQUES, 1993).

O gênero Pseudoplatystoma, que compreende os maiores peixes da família Pimelodidae e pode ser encontrado nas principais bacias hidrográficas sul-americanas. Amazônica, do Prata e São Francisco, é constituído pelas espécies P. coruscans (surubim, pintado).

A importância ecológica do surubim pode ser evidenciada pelo fato de ele ser o segundo maior peixe predador da bacia do Paraná e o primeiro da bacia do São Francisco e pela sua abundância em ambas.

\subsection{Fatores ambientais e a extinção do Pseudoplatystoma coruscans}

Um dos fatos relevantes da espécie, é estar ocupando um habitat crescentemente alterado pelas ações antrópicas, com grandes riscos de desaparecimento, como já foi verificado em trechos das duas bacias citadas (MARQUES, 1993; SATO; CARDOSO; AMORIM, 1987).

As construções de barragens, constantes hidrelétricas em operação, juntamente a outros fatores ambientais, tem causando a perda das características originais dos rios, transformando os grandes rios em uma sucessão de grandes lagos artificiais o que tem interferindo no comportamento migratório das espécies (ALVES, 1995; GODINHO; GODINHO, 1994), causando sérios prejuízos à reprodução do Pseudoplatystoma coruscans, que tem levado o surubim a ameaça de extinção. Portanto, estudos que visam à obtenção e criação de Pseudoplatystoma coruscans, são necessários com a finalidade inclusive de preservar a espécie. 
O pintado é um peixe de hábito alimentar carnívoro, que requer alto teor protéico em sua alimentação, sua criação pode ser viável em reservatórios que ofereçam condições ao desenvolvimento do seu ciclo reprodutivo e alimentação natural em abundância, na forma de peixes forrageiros de pequeno porte e pouco valor comercial (SATO et al., 1997).

Os peixes migradores ou seja os de piracema, vêm sendo dizimados em ritmo acelerado sem que técnicas adequadas de produção sejam estabelecidas em função, principalmente, do desconhecimento da sua bioecologia e sabe-se que os mesmos, dentre eles o surubim, além de serem vulneráveis a concentração indiscriminada do esforço de pesca sobre seus cardumes na época da reprodução, são ainda ameaçados constantemente pelas alterações ambientais advindas do uso múltiplo dos sistemas fluviais, principalmente em relação às alterações das características das enchentes, que têm como conseqüências, mudanças nas populações íctias, determinando a diminuição dos seus estoques. Estas conseqüências, apesar de serem já relativamente conhecidas (AGOSTINHO; JÚLIO; BORGUETTI, 1992; BRITSKI, 1994; FISCHER; CHAGAS; DORNELLES, 1992; GODINHO; GODINHO, 1994; GODOY, 1979; PAIVA; BASTOS, 1982; PETRERE, 1994; PINTO-COELHO; GIANNI; VON SPERLING, 1994; SATO, 1995; TORLONI, 1995; WELCOMME, 1980) são, até o momento, pouco consideradas para o planejamento de utilização de uma bacia hidrográfica (MENANDRO, 1994; MENEZES, 1994).

Em geral, os peixes de piracema são os de maior valor comercial, principalmente o dourado Salminus brasiliensis e o surubim Pseudoplatystoma coruscans (SATO; OSÓRIO, 1988a) que, juntamente, com a matrinchã Brycon lundii, e o pacamã Lophiosilurus alexandri são espécies hoje raramente capturadas na represa de Três Marias e que podem ser consideradas em extinção a sua montante na região do Alto São Francisco (SATO et al., 1987). 


\subsection{A importância econômica da criação de Pseudoplatystoma coruscans}

A piscicultura é hoje uma das principais fontes de subsistência para o Brasil e em outros países, tornou-se fator econômico essencial. No Brasil, a piscicultura tem-se desenvolvido fundamentalmente com espécies exóticas, em função da pouca tecnologia para a criação de espécies nativas (MIRANDA, 1993).

Vários são os fatores que têm contribuído para aumentar o interesse pelo estudo dos peixes de água doce. Dentre eles, pode-se considerar que o aumento de lagos artificiais, relacionados com a construção de hidrelétricas, promove o seu aproveitamento para uma maior produção de peixes. Com isto, torna-se necessário estudar e conhecer melhor a biologia e ecologia das espécies dessas áreas explica (BRITSKI; SATO; ROSA, 1988).

O Pseudoplatystoma coruscans, vulgarmente conhecido como pintado, é uma das espécies que justifica sua utilização na piscicultura, devido a sua importância econômica e a sua demanda não apenas pelos consumidores, como também pelos piscicultores, explica (MIRANDA, 1993).

Sem dúvida, a espécie $P$. coruscans tem importante participação na produção pesqueira das bacias em que ocorre (MARQUES, 1993). É por exemplo, relacionada entre as espécies de importância comercial no rio Paraná em Rosário na Argentina (WELCOMME, 1985) e considerada como uma das mais freqüentes nas capturas efetuadas nos trechos Alto, Médio e Inferior do mesmo rio (ROS; DELFINO, 1994).

Durante o período de 1987 a 1990, o pintado foi no reservatório de Itaipu uma das nove espécies mais capturadas na pesca profissional (AGOSTINHO, 1994). Por sua vez, a participação do surubim na produção de pescado na bacia do São Francisco é também substancial (FERRAZ DE LIMA; MIRANDA et al., 1988), tendo representado 86,3\% do total capturado em um estudo de acompanhamento da pesca profissional realizado em 1987 
(GODINHO et al.,1990), constituindo-se na principal meta de captura de $100 \%$ dos pescadores profissionais daquele rio (MIRANDA et al., 1988).

A importância econômica da espécie na pesca profissional, tanto na bacia do rio São Francisco quanto nos grandes centros consumidores das regiões Nordeste e Sudeste, tem sido enfatizada há mais de cem anos, através de inúmeros relatos (MENEZES, 1956; SATO; AMORIM; CARDOSO, 1988a). A importância comercial da espécie $P$. coruscans é, então, devida a alta qualidade de sua carne (REID, 1983), ao seu elevado valor de comercialização e a sua marcante participação na pesca comercial nas diferentes regiões em ocorre (MARQUES, 1993).

Também, resultados obtidos em trabalho de pesquisa em zootecnia na área de Produção Animal, desenvolvidos na UFMG, com o objetivo de estabelecer e relacionar índices zootécnicos e características de carcaça para o surubim P. coruscans do rio São Francisco, de forma a subsidiar estudos posteriores de seleção e melhoramento, sugerem que o surubim apresenta um crescimento total aparentemente isométrico, considerando todos os seus índices zootécnicos, e características e rendimento de carcaça que o credenciam, sob esses aspectos, como uma espécie com alto potencial para a produção comercial (MIRANDA, 1993).

Outra pesquisa na área de melhoramento, também realizada na mesma instituição e que desenvolver estudo citogenético em surubim $P$. coruscans, concluiu, quanto às perspectivas para a exploração de cruzamentos para a obtenção de híbridos, que a semelhança de citótipos permite prever a possibilidade de cruzamentos entre indivíduos das bacias dos rios São Francisco e Paraguai, cruzamentos estes de grande valor, tanto para a aqüicultura quanto para a realização de possíveis repovoamentos de áreas antes ocupadas por esta espécie (SOUSA, 1993; SOUSA et al., 1994). 
No momento, o surubim $P$. coruscans pode ser considerado juntamente com o pirarucu Arapaima gigas, o dourado Salminus maxillosus, os tucunarés gênero Cichla e a pirarara Phractocephalus hemiliopterus, todas espécies nativas de hábito alimentar piscívoro/carnívoro, como uma espécie de potencial para criação como peixe de mesa food fish, esportivo ou mesmo ornamental (KUBITZA, 1995) de interesse, inclusive, para exportação (CURY, 1992; RABELLO, 1992; TOLEDO, 1991)

\subsection{Hábitos alimentares e estruturação do trato digestório dos peixes}

Os peixes, que representam mais da metade da ordem Vertebrata e constituem um grupo extremamente variado ocupam diferentes nichos ecológicos e níveis tróficos e têm amplo espectro alimentar, apresentando, como conseqüência, diferentes hábitos alimentares (CUENCA; GALLEGO, 1987).

Considerando que há uma rica ictiofauna nativa no Brasil, poucos são os trabalhos elaborados a respeito da estrutura do aparelho digestório. Estudos estes que, paralelamente aos dos aspectos reprodutivos, são fundamentais para o desenvolvimento da piscicultura no país.

Em geral, os estudos realizados restringiram-se a descrição do trato digestório de uma espécie, sendo pouco numerosos os que se preocuparam em ressaltar as adaptações da estrutura trófica aos hábitos alimentares (MENIN, 1988).

Há diversos trabalhos classificando os peixes quanto aos seus hábitos alimentares (ANGELESCU; GNERI, 1949; CASTAGNOLLI, 1992; KAPOOR et al., 1975a; NIKOLSKY, 1963; PREJS, 1981).

A natureza do alimento ingerido, pode-se diferenciar os peixes em três categorias, cujos limites são imprecisos: (1) herbívoros; (2) carnívoros; e (3) onívoros. A primeira 
categoria pode ser subdividida, de acordo com a espécie do alimento particular e as condições ecológicas, em: fitoplanctófagos, macrofitófagos, perifitófagos e detritófagos. Da mesma forma, os carnívoros podem ser considerados como zooplanctófagos, bentófagos e ictiófagos. Ainda com relação à diversidade do alimento, os peixes podem ser considerados como: (1) eurífagos, cuja dieta é mista e variável; (2) estenófagos, cuja dieta é mais estável; (3) monófagos, que consomem um tipo único de alimento (PREJS, 1981).

No entanto, segundo (WEATHERLEY; GILL, 1987), em situações de criação intensiva, peixes carnívoros e herbívoros podem utilizar ingredientes similares na formulação da dieta, porém em proporções diferentes. Pode-se salientar, ainda, que todos os peixes que não são carnívoros típicos ou consumidores de zooplâncton podem ser considerados, no sentido amplo, como onívoros, sempre que possuam um regime alimentar misto (MENIN, 1988).

Conhecer a nutrição dos peixes é essencial, pois fornecerá informações no manejo alimentar, visto que a nutrição adequada é fundamental para o seu desempenho e a sua sobrevivência (CYRINO et al., 1998).

O conhecimento da estrutura dos órgãos do aparelho digestivo dos peixes auxilia no entendimento de como eles se adaptam ao ambiente e a dieta. Este fato contribui para o aumento da eficiência alimentar e para a redução dos custos com a alimentação, tornando a aqüicultura ainda mais atrativa.

Há estreitas relações de interdependência entre a nutrição, o hábitat e a organização do trato digestório, as quais se manifestam especialmente por adaptações e modificações. A dieta confere aos órgãos desse aparelho características funcionais, anatômicas e morfométricas, próprias para cada regime alimentar (ANGELESCU; GNERI, 1949).

Os peixes apresentam necessidades nutricionais bastante diferenciadas ao longo do seu ciclo de vida. Isto é verdadeiro principalmente nos sistemas de criação mais intensivos, 
quando as dietas artificiais desempenham um papel ainda maior na sua nutrição. Para que possam ser discutidas as exigências nutricionais dos peixes nas várias fases do ciclo de vida, deve-se conhecer o desenvolvimento de nutrientes (ZIMMERMANN; JOST, 1998).

Estudos anatômicos e histológicos do aparelho digestivo de peixes são justificados, em virtude de se poder inferir a respeito de sua alimentação, por meio de características estruturais deste aparelho (MENIN, 1988).

É essencial intensificar as pesquisas com a espécie surubim Pseudoplatystoma coruscans, principalmente no que concerne à nutrição, favorecendo a ampliação do seu potencial zootécnico, uma vez que, além de ser uma espécie nativa, é a maior do gênero, podendo atingir peso corporal acima de $100 \mathrm{~kg}$ com carne de excelente qualidade (SATO; AMORIM; CARDOSO, 1988a).

\subsection{Ontogenia do trato digestório de peixes}

Durante o processo de desenvolvimento dos peixes, podem ser observadas mudanças em seus hábitos alimentares ou nas suas dietas, que ocasionam adaptações morfológicas no aparelho digestivo. À medida que o peixe cresce, acontecem modificações substanciais na estrutura e no comprimento do tubo digestivo (PREJS, 1981). O autor citou por exemplo que, em Hypophthalmichthys molitrix, cujas larvas alimentam-se de zooplâncton, o intestino é muito curto, menos de $100 \%$ do comprimento do corpo, enquanto, no adulto, que é fitoplanctófago, o comprimento intestinal é cerca de 15 vezes o comprimento do corpo.

Em Labeo rohita foram encontradas variações no tubo digestivo durante o seu crescimento. Essa espécie, na fase de alevino, apresenta-se como zooplanctófaga, com tubo digestivo curto, típico de carnívoro, enquanto, na fase adulta, é tipicamente fitoplanctófaga, 
com tubo digestivo desenvolvido, apresentando muitas circunvoluções, típico de herbívoros (SINHA; MOITRA, 1975a)

$\mathrm{Na}$ maioria das espécies de peixes, após a eclosão, o tubo digestivo das larvas apresenta-se como um tubo simples, reto, não diferenciado, como em Salmo trutta (BURNSTOCK, 1959); Chanos chanos (FERRARIS; TAN, J. D.; DE LA CRUZ, 1987); Lates calcarifer (WALFORD; LAM, 1993); Hoplias cf. lacerdae e Lophiosilurus alexandri (NEVES, 1996).

Em experimento realizado sobre o desenvolvimento ontogenético do tubo digestivo de Hoplias cf.lacerdae (trairão), observaram que, no primeiro dia pós-eclosão, o esôfago apresenta-se como um cordão celular fino e o intestino, basicamente, como um túbulo retilíneo com mucosa desprovida de pregas; aos três dias de vida, a mucosa pregueada do estômago possui epitélio prismático simples; aos 12, foram observados alimentos no estômago e grânulos de secreção nas células glandulares; e, aos 50 dias, o desenvolvimento foi completado (NEVES; GODINHO, 1995). Aos 25 dias, os mesmos autores evidenciaram numerosos cecos pilóricos, distribuídos sobre a porção cranial do estômago.

Em estudos semelhantes realizados, com Hoplias malabaricus (traíra), observaram os seguintes acontecimentos: no terceiro dia pós-eclosão, o intestino e o estômago são bem visíveis, cheios de um líquido amarelado que facilita a sua transparência; no sexto dia, o tubo digestivo apresenta curvatura dilatada, e o estômago, se encontra cheio de alimento; ao fim de uma semana, o tubo digestivo acha-se bem constituído, sendo possível distinguido o esôfago, estômago e intestino, e com pouco mais de um mês, o tubo digestivo mantém sua forma, sem grandes modificações, terminando, assim, a completa metamorfose da larva, a qual passa de planctófaga, para consumir insetos ou seja, tornando-se entomófaga, (AZEVEDO; GOMES, 1943). 
Durante a ontogenia do trato digestivo, glândulas multicelulares foram observadas por (BAGLOLE et al., 1997; CATALDI et al., 1987; GRIZZLE; CURD, 1978; VU TAN TUE, 1980), nas espécies por eles estudadas.

Com o crescimento da larva, o comprimento e a complexidade do tubo digestivo vão se caracterizando de acordo com a espécie e seu hábito alimentar. Vários são os trabalhos, com diferentes espécies de distintos hábitos alimentares, em que foi observado aumento no comprimento intestinal com o aumento do comprimento do corpo, tais como:Aristichthys nobilis (OPUSZYNSKI; SHIREMAN, 1991); Perca flavescens (DABROWSKI; CULVER, 1991).

Quanto mais profunda for a mudança no hábito alimentar da espécie, durante o seu desenvolvimento, maior será a variação nas características do tubo digestivo, principalmente no comprimento intestinal.

O estudo da ontogenia em várias espécies de peixes tem se intensificado nos últimos anos, e alguns autores observaram a presença de células caliciformes no intestino médio e no intestino posterior, com diferentes distribuições, de acordo com a espécie estudada: Labeo rohita (SINHA; MOITRA, 1975a), Cirrhinus migala (SINHA; MOITRA, 1975b), Percina caprodes (GRIZZLE; CURD, 1978), Dicentrarchus labrax (VU TAN TUE, 1980), Pseudoplatystoma coruscans (SANTOS; GODINHO, 1994), Sparus aurata (SARASQUETE; POLO; YÚFERA, 1995), dentre outros.

\section{ESÔFAGO}

O esôfago é a parte do tubo digestivo que une a faringe ao estômago ou então ao intestino naquelas espécies de peixes onde o estômago está ausente, como observado em “carpa" Cyprinus carpio communis, (CURRY, 1939), Varicorhinus capoeta sevangi, 
(VERIGINA, 1969), Cirrhinus migala, (SINHA; MOITRA, 1975b), Labeo rohita, (SINHA; MOITRA, 1975a) e Ctenopharyngodon idella, (TREVISAN, 1979).

Os aspectos anatômicos do esôfago como comprimento e forma, variam geralmente conforme o comprimento do animal. Como exemplo temos os cações que são peixes alongados, o esôfago é longo e as raias que são peixes achatados, o esôfago é curto, acrescida a estas observações há variação no tipo de alimentação (ZAMITH, 1952).

A luz do esôfago pode ser constituída por pregas, que podem ser classificadas em primárias, secundárias (SIS et al., 1979) e terciárias (GOHAR; LATIF, 1960). Na espécie Narcine brasiliensis, o esôfago é liso, portanto ausente em pregas (ZAMITH, 1952).

O epitélio de revestimento do esôfago é bastante variável nas diferentes espécies, os quais a seguir, são relatados em uma breve citação. O epitélio pavimentoso estratificado com células mucosas que às vezes podem ser tão numerosas, mascarando o caráter estratificado do epitélio (BORGES, 1981; CLARKE; WITCOMB, 1980; MARTIM; BLABER, 1984), podendo sua quantidade aumentar no sentido crânio-caudal (BISHOP; ODENSE, 1966; BORGES, 1981) ou diminuir (MARTIM; BLABER, 1984).

As células mucosas são glândulas unicelulares especializadas na função secretora, pois produzem um fluido viscoso, rico em glicoproteínas (BANKS, 1992). As células mucosas estão relacionadas à lubrificação do alimento e a proteção do epitélio contra a abrasão física (AGRAWAL; MITTAL, 1991, 1992). Além de serem identificadas no esôfago também foram encontradas na cavidade bucofaringeana de teleósteos adultos (ANDERSON, 1986, BISHOP; ODENSE, 1966; BRAGANÇA; MENIN; COSTA, 1992, CATALDI et al., 1987, GUPTA, 1971, MENIN, 1988, MURRAY; WRIGTH; GOFF, 1994b; TAN; TEH, 1974, VASQUES et al., 1998).

De acordo com o seu produto de secreção, as células mucosas podem ser de três tipos: produtoras de mucopolissacarídeos neutros, produtoras de mucopolissacarídeos ácidos e 
produtos de ambos (EZEASOR, 1984; REIFEL; TRAVILL, 1978b) sendo que o mais freqüente é encontrar os dois, mucopolissacarídeos ácidos e neutros (BORGES, 1981; GOMES, 1981 REIFEL; TRAVILL, 1978b).

O epitélio colunar simples reveste o esôfago de alguns peixes como Salmo trutta, (BURNSTOCK, 1959), Chelmon rostratus (TAN; TEH, 1974) Hoplosternum thoracatum, (HUEBNER; CHEE, 1978); e as células colunares produzem mucopolissacarídeos. O epitélio cúbico estratificado, observado no esôfago de Salmo gairdneri, (WEINREB; BILSTAD, 1955) e o epitélio cilíndrico estratificado observado no esôfago de Prionotus carolinus, por (BLAKE, 1936).

\section{ESTÔMAGO}

Para a maioria dos peixes, o estômago pode apresentar semelhança com as letras: U, J, ou Y. Além destas formas, o estômago apresenta uma grande variedade de outras formas. Nos gêneros Pomatoschistus, Gasterosteus, Spinachia, foram encontradas a forma tubular reta. Nos gêneros Limanda, Pleuronectes, encontrou-se a forma curva, (SUYEHIRO, 1942). Na tilápia e nos gêneros Myoxocephatus e Enophrys, a forma é sacular, já nos gêneros Gymnarchus, Ophiocephalus, Anguilla, a forma é cecal, (RAUTHER, 1910).

Podemos encontrar três outros grupos de estômago, de acordo com sua forma: tipo sifonal, cecal e retilíneo; acrescido das formas intermediárias. A forma sifonal possui um ramo descendente chamado de cárdico e um ramo ascendente chamado de pilórico. Na forma cecal, ocorre uma região de união em fundo cego, que nada mais é que a interposição entre os dois segmentos (BERTIN, 1958). O estômago de forma retilíneo é o menos freqüente (MARTIM; BLABER, 1984). 
A divisão do estômago em região cárdica, fúndica e pilórica, tomando como critério a estrutura anatômica e a presença ou não de glândulas gástricas foi possível observar nos trabalhos de (CLARKE; WITCOMB, 1980; GODINHO; TOKUMARU; FERRI, 1970; GOMES, 1981).

As pregas primárias da mucosa estomacal podem ou não ser longitudinais (ALHUSSAINI, 1946; MACDONALD, 1987). Pregas secundárias foram descritas por (MACDONALD, 1987; MARTIM; BLABER, 1984; SIS et al., 1979).

O estômago dos peixes é revestimento por epitélio do tipo colunas simples (DOMITROVIC; MOREIRA, 1984; EZEASOR, 1981; KAPOOR; SMIT; VERIGHINA, 1975b).

O epitélio colunar secreta muco, com as seguintes composições químicas: mucopolissacarídeos neutro e ácido carboxilado e sulfatado (GOMES, 1981; JIRGE, 1970; KUCHINSKI, 1985); mucopolissacarídeos neutro e ácido carboxilado (BUCKE, 1971; CLARKE; WITCOMB, 1980); mucopolissacarídeos neutros (REIFEL; TRAVILL, 1978b; SANTOS; MENDES FILHO; NEPOMUCENO, 1979).

Observou-se no estômago de Plecostomus plecostomus que o epitélio era do tipo pavimentoso simples, tornando-se colunar simples na região pilórica (PETRINI, 1961).

As invaginações do epitélio originam as fóveas gástricas que estão presentes na maior parte dos teleósteos estudados (DOMITROVIC; MOREIRA, 1984; GOMES, 1981). As fóveas gástricas estão revestidas por células ligeiramente menores que as superfícies (ALVES, 1966; BLAKE, 1936).

Em peixes da família Centrarchidae a composição química do produto de secreção das células das fóveas produziu mucopolissacarídeos ácidos e neutros, enquanto que no restante das células, a secreção continha somente mucopolissacarídeos neutros (REIFEL; TRAVILL, 1978b). 
As glândulas gástricas podem abrir-se na luz do estômago de duas maneiras: no fundo das fóveas (KAPOOR; SMIT; VERIGHINA, 1975a; GOMES, 1981) ou diretamente na superfície do estômago, entre as células colunares (MARTIM; BLABER, 1984).

A estrutura histológica das glândulas gástricas, apresenta variações em sua intensidade adaptativa, de acordo com o tempo de digestão. Essas glândulas estão envolvidas no processo digestivo (MOHSIN, 1962), onde seriam responsáveis pela produção de ácido clorídrico (IRO, 1967) e provavelmente secretam pepsinogênio (TAN; TEH, 1974). Por sua vez, (CONNES; BENHALIMA; PARIS, 1983), em estudos ultra-estruturais das células que compõem as glândulas do estômago de Dicentrarchus labrax, afirmaram que estas produzem, simultaneamente, ácido clorídrico e pepsinogênio, qualificando-as de oxintopépticas.

A existência de glândulas multicelulares no estômago dos peixes foi observada em espécies com hábitos alimentares distintos, destacando os seguintes trabalhos: (BARRINGTON, 1957; CATALDI et al., 1987; GARGIULO et al., 1998; LING; TAN 1975; MURRAY et al., 1994a; NOAILLAC-DEPEYRE; GAS, 1978).

As glândulas gástricas são em geral do tipo simples e tubulosas (BARRINGTON, 1957). Nestas glândulas só foi identificado um tipo celular (BARRINGTON, 1957; KAPOOR; EVANS; PEVENER, 1975a), a célula parietal ou oxintopéptica, que secreta ácido clorídrico e enzimas digestivas (MEDEIROS, 1970b; OGURI, 1979; SARBAHI, 1951; WESTERN; JENNINGS, 1970).

Em Plecostomus commersonii, essas glândulas estão ausentes e não são vistas as células oxintopépticas (BORGES, 1981).

Foram identificados mucopolissacarídeos neutros e ácidos no citoplasma das células glandulares em Tilapia mossambica, (JIRGE, 1970); Pimelodus maculatus, (MEDEIROS, 1970a); Plagioscion equamosissimus, (SANTOS; MENDES FILHO; NEPOMUCENO, 1979) e Rhamdia branneri, (GOMES, 1981). 


\section{INTESTINO}

O intestino dos Teleósteos, embora basicamente mais simples que o dos Vertebrata superiores, apresenta numerosas variações específica, em geral no que se refere à estrutura anatômica e ao comprimento (REIFEL; TRAVILL, 1978a).

As adaptações do intestino, desde o comprimento e o arranjo na cavidade peritoneal até a estrutura da mucosa, é um dos aspectos mais estudados, em nível anatômico, nas interações com o ambiente, no regime alimentar e no trato digestório dos peixes.

O trato digestório dos peixes pode ser dividido em: intestinos cefálicos, que compreende a cavidade bucofaringeana, ou seja, a boca e seus anexos e a faringe; intestinos anteriores, que compreende o intestino propriamente; e intestino posterior, para os peixes que não possuem a válvula ileorretal, e o reto, para os que a possuem. Estes dois últimos desembocam no ânus (BERTIN, 1958).

$\mathrm{Na}$ literatura verifica-se que o intestino é reconhecido por várias denominações e dividido em distintas porções por diferentes autores, até mesmo em relação a uma determinada espécie, alguns deles fundamentando-se em características anatômicas, outros, em histológicas e ainda outros, em funcionais.

Do ponto de vista morfológico, o intestino dos peixes é composto por duas partes: intestino médio, compreendendo intestino e cecos pilóricos, e intestino posterior, que compreende o reto (WESTERN, 1969). Já Tan e Teh (1974) denominaram-nos de intestino delgado e reto; enquanto (BISHOP; ODENSE, 1966), de íleo e reto; (BUCKE, 1971), de intestino anterior e posterior; (MOTA ALVES; TOMÉ, 1966; MOTA ALVES, 1969), de intestino anterior, constituído de duodeno e íleo, e posterior, formado pelo reto; dentre outros.

O segmento intestinal correspondente anatomicamente ao intestino médio é reconhecido por várias denominações e subdividido em distintas porções por diferentes 
autores, até mesmo para uma determinada espécie, verificado na literatura por (MENIN; 1988).

Com base nesses fatos, Menin (1988) e Logato (1995) relataram que existem diferentes critérios e grande discordância entre diversos autores para se proceder à distinção dos segmentos intestinais dos peixes, alguns fundamentados em características anatômicas, outros, em histológicas, e ainda outros, em funcionais, e concluíram que a divisão do aparelho digestivo de BERTIN (1958) seria a que melhor define esses segmentos, além de ser a mais utilizada no País.

O intestino propriamente dito, segundo o critério histofisiológico, é dividido em: primeiro segmento ou proximal (60-75\% do comprimento total), segundo segmento ou médio (20-25\%) e terceiro segmento ou distal (5-15\%) (STROBAND; DABROWSKI, 1979).

De acordo com o critério histofísiológico, o primeiro segmento encontra-se relacionado com a absorção de gorduras (IWAI, 1969; NACHI, 1988). O epitélio é constituído por células colunares, absortivas ou enterócitos; compondo o epitélio, temos também as células caliciformes (BLAKE, 1930, 1936; AL HUSSAINI, 1947, 1949b).

O segundo segmento ou segmento médio, descreve-se como responsável pela absorção de macromoléculas protéicas (GAUTHIER; LANDIS, 1972; STROBAND; KROON, 1981a; STROBAND; VAN DER VEEN, 1981b). Em relação ao segmento proximal, o epitélio desta região difere pelo maior número de células caliciformes e apresenta diferenças citológicas e citoquímicas em relação aos enterócitos (AL HUSSAINI, 1949b).

O terceiro segmento ou segmento distal, encontra-se relacionado com a absorção de água e eletrólitos. O epitélio difere das outras regiões, por apresentar maior número de células caliciformes (AL HUSSAINI, 1949b).

O comprimento do intestino pode varia conforme o hábito alimentar dos peixes, sendo o intestino mais curto encontrado mais freqüentemente nos carnívoros que nos onívoros e o 
mais longo, nos herbívoros e ictiófagos que nos onívoros (AL-HUSSAINI 1949a, KAPOOR, 1975a; KHANNA, 1971).

Em várias espécies da família Cichlidae, relacionaram o comprimento do intestino com os seus hábitos alimentares. Em Tilapia nilótica, espécie herbívora, o intestino mede cerca de seis vezes o comprimento do corpo, enquanto em Astronotus ocelatus, espécie carnívora, o comprimento do intestino é, aproximadamente, igual ao comprimento do corpo (FARIAS; INTELIZANO, 1982). Em Tilápia mossambica, espécie carnívora, uma relação comprimento do intestino/comprimento do corpo igual a 8:1 (PASHA, 1964).

O comprimento do intestino em Hoplias malabaricus, espécies ictiófaga, e Pimelodus sp., espécie preferencialmente carnívora, é mais curto que em Leporinus reinhardti e Brycon Lundii, ambas espécies onívoras; em Prochilodus marggravii e Prochilodus affinis, espécies ictiófagas, o intestino é mais longo, segundo (MENIN, 1988).

Em cinco espécies de Teleostei, onívoras e as planctófagas têm intestino de comprimento intermediário (KHANNA; MEHROTRA, 1971). Os carnívoros Gobio gobio e Pteroi apresentam intestino muito longo (AL-HUSSAINI, 1949a).

Apesar dos inúmeros trabalhos em que foi possível estabelecer a relação entre comprimento do intestino com hábito alimentar, não é possível generalizar essa relação. Por exemplo, (AL-HUSSAINI, 1947; REIFEL; TRAVILL, 1978a), concluíram que as espécies planctófagas têm intestino mais curto; as herbívoras, mais longos; enquanto as carnívoras apresentam intestino de comprimento intermediário.

A estrutura morfológica do tubo digestivo não permite tirar conclusões evidentes sobre os hábitos alimentares, pois existem peixes carnívoros agástricos e herbívoro com tubo digestivo curto, declarou (DABROWSKI, 1993). As espécies planctófagas têm intestino mais curto, as herbívoras, mais longo, enquanto as carnívoras apresentam intestino de comprimento intermediário (AL-HUSSAINI, 1947; REIFEL; TRAVILL, 1978a). Entretanto, as variações 
no comprimento do intestino são compensadas por variações na área da mucosa intestinal, o que explica a ocorrência de alguns peixes herbívoros com intestino curto e carnívoros com intestino longo (AL-HUSSAINI, 1949a).

Além do comprimento intestinal, alguns autores procuraram relacionar o hábito alimentar com: (1) coeficiente intestinal; (2) arranjo das alças intestinais; e (3) grau de complexidade das pregas da mucosa.

As relações entre o comprimento do intestino e os hábitos alimentares puderam ser expressas matematicamente, estabeleceu-se um coeficiente, denominado coeficiente intestinal, que varia conforme os hábitos alimentares dos peixes: nos carnívoros, essa relação está compreendida entre 0,2 e 2,5; nos onívoros, entre 0,6 e 0,8 e nos herbívoros, entre 0,8 e 15,0 (BERTIN, 1958). Vários autores observaram valores de coeficientes intestinais condizentes com os intervalos encontrados por (BERTIN, 1958; LOGATO, 1995; MENIN, 1988), entre outros.

A anatomia funcional do intestino de Hoplias malabaricus, espécie ictiófaga; Pimelodus sp., espécie preferencialmente carnívora; Leoporinus reinhrdti e Brycon lundii, espécies onívoras; Prochilodus marggravii e Prochilodus affinis, espécies iliófagos; e Gymnotus carapo, espécies carnívora, aponta valores dos coeficientes intestinais, particulares a cada uma delas, estando condizentes com os intervalos propostos por (BÉRTIN, 1958), para os distintos hábitos alimentares, podendo-se afirmar que, para essas espécies, há correlação entre o comprimento relativo do intestino e o hábito alimentar (MENIN, 1988).

As alças intestinais estão dispostas na cavidade peritoneal, com arranjo retilíneo, quando o intestino for curto, e com uma ou mais circunvoluções, quando o intestino for mais longo ressaltaram (KHANNA; MEHROTRA, 1971; LOGATO, 1995).

O padrão linear, ou quase linear, foi observado em grande número de espécies ictiófagas ou carnívoras por (SUYEHIRO, 1942, AL-HUSSAINI, 1947; KHANNA; 
MEHROTRA, 1971). Em Pimelodus sp. espécie predominantemente carnívora, o intestino é quase retilíneo e que as circunvoluções das alças finais do intestino médio talvez possam ser vistas como adaptação ao regime onívoro, uma vez que alongam o intestino e, provavelmente, o adaptam para melhor aproveitamento do material vegetal deglutido (MENIN, 1988).

Nos Prochilodontidae, espécie iliófagas, o complexo padrão, em enrolamento inverso do intestino, possibilita a condução do material alimentar alternada e continuamente em sentido cranial e caudal. Esse padrão pode ser considerado uma adaptação ao tipo de alimento ingerido, que proporciona, ainda, economia de espaço na cavidade abdominal, assegurando o transporte mais lento do material em processamento, e, assim, permitindo a extração mais completa das substâncias nutritivas (ANGELESCU; GNERI, 1949; MENIN, 1988). Este complexo padrão também foi encontrado em outro iliófagos, como alguns Cyprinidae, e dentre os herbívoros,Tilápia mossambica (PASHA, 1964). Em Brycon lundii e Leporinus reinhardti o padrão, em enrolamento inverso e em N, respectivamente (MENIN, 1988) e em Piaractus mesopotamicus enrolamento em N (LOGATO, 1995); espécies onívoras, foi considerado, pelas autoras citadas, como adaptação a uma alimentação com valores nutricionais intermediários entre os dos ictiófagos e os dos herbívoros ou dos iliófagos.

A relação da estrutura da mucosa intestinal com os processos fisiológicos de digestão e absorção dos teleósteos, foi estudada por (ANGELESCU; GNERI, 1949), e estes afirmaram que a região com as pregas mais complexas estariam envolvidas os processos absortivos, dado o aumento da área efetiva para a absorção dos nutrientes.

A literatura disponível, mostra que as mais diversas espécies, possuem a mucosa intestinal pregueada, sendo as pregas mais elaboradas em algumas espécies e menos em outras (MENIN, 1988).

O padrão encontrado da mucosa intestinal, pode ser mais elaborado em algumas espécies e menos em outras existindo desta forma uma grande variabilidade no tipo de pregas 
intestinais entre as espécies, e ainda, entre as diferentes partes do intestino em um mesmo individuo, podendo ser longitudinais ou transversais, retilíneas ou sinuosas (BERTIN, 1958).

O padrão da mucosa intestinal é mais complexo em Prochilodontidae, os de complexidade intermediária em Hoplias malabaricus e Pimelodus sp., espécie ictiófaga e principalmente carnívora, respectivamente, e os menos complexos em Brycon lundii e Leporinus reinhardti, espécie onívoras. Assim, quanto mais baixo o valor nutricional do alimento, mais elaborados são os relevos do intestino constatado por (MENIN, 1988).

A mucosa mais complexamente estruturada pode ser encontrada nas espécies carnívoras (KHANNA; MEHROTRA, 1971).

As pregas intestinais mais complexas e desenvolvidas são as dos Prochilodontidae, iliófagas, e que pregas menos desenvolvidas do que as destes, mas com arranjo ainda bastante elaborado, são encontradas em Hoplias malabaricus, ictiófaga, e Pimelodus sp., predominantemente carnívora. Em Brycon lundil e Leporinus reinhardti, ambas onívoras, as pregas intestinais, menos complexas do que as das espécies anteriores, apresentam-se mais elaboradas na última, em cuja alimentação predomina o material de origem vegetal (MENIN, 1988)

Muitas espécies de peixes apresentam projeções digitiformes, os cecos pilóricos, que se situam no início do segmento proximal (BERTIN, 1958). Os cecos apresentam-se com uma mucosa revestida por epitélio simples colunar com muitas células secretoras de muco (ALHUSSAINI, 1946). Com base nas estruturas anatômicas e histológicas, atribuíram-se as funções de secreção de muco e de ampliação da superfície de absorção de nutrientes, para os cecos pilóricos das espécies estudadas por (MENIN, 1988). 


\subsection{Células caliciformes}

Dentre as células epiteliais especializadas, isoladas, dotadas de função secretora, as mais bem estudadas são as células caliciformes, assim denominadas em virtude da sua aparência em forma da cálice. Geralmente, apresentam-se entremeadas a outras células epiteliais e secretam mucinogênio.

Em peixes, as células caliciformes podem ser encontradas nos intestinos médio e posterior, assim como nos cecos pilóricos; nestes, porém, em menor número (KHANNA; MEHROTRA, 1971, MENIN, 1988).

A presença de células caliciformes ao longo dos intestinos médio e posterior em peixes Teleostei adultos é relatada por vários autores (ANDERSON, 1986; BUCKE, 1971; CATALDI et al., 1987; CHAUDRY; KHANDELWAL,1961; GARGIULO et al., 1998; LOGATO, 1995; MARTIN; BLABER, 1984; MORAES; BARBOLA; GUEDES, 1997; TAN; TEH, 1974; TREVISAN, 1979; VU TAN TUE, 1980), dentre outros.

No epitélio do segmento distal do intestino, existe um número maior de células caliciformes (AL-HUSSAINI, 1949b). Ocorre nesse segmento maior atividade destas células secretoras de muco. Estas são mais evidentes ao lado das pregas de mucosa do intestino, embora apareçam ocasionalmente agrupadas na extremidade (CACECI, 1984). É na mucosa que são absorvidos a água e os eletrólitos. Em Labeo rohita, ocorrem poucas células caliciformes ou globosas no intestino proximal e médio, sendo numerosas essas células no segmento distal (SINHA, 1983).

Poucos registros têm sido feitos sobre a presença de glândulas multicelulares no epitélio intestinal dos teleósteos, assim como sua provável função. Vários autores afirmaram que não são verificadas glândulas multicelulares no intestino dos peixes (BARRINGTON, 1957; MOHSIN, 1961; TAN; TEH, 1974), enquanto outros registraram sua presença nas 
espécies por eles estudadas Prionotus carolinus (BLAKE, 1936), Gadus morhua (BISHOP; ODENSE, 1966), Xenentodon cancila (GUPTA, 1971), Prochilodus affinis e Prochilodus marggravii (MENIN, 1988). 


\section{MATERIAL E MÉTODOS}

Os ovócitos de pintado Pseudoplatystoma coruscans (Siluriformes, Pimelodidade) foram obtidos por extrusão e fertilizados, a partir de reprodutores mantidos em cativeiro. Após a hidratação, os ovos foram acondicionados em sacos plásticos de 60 litros e transportados para a Unidade de Pesquisa e Desenvolvimento (UPD)/APTA/Secretaria de Agricultura e Abastecimento, localizada no Distrito de Cachoeira de Emas em Pirassununga - SP. Em seguida os ovos foram incubados em recipientes cilindros-cônicos com fluxo contínuo de água, mantidos sob fotoperíodo natural, de cerca de 13 horas de duração, porém em condições de iluminação reduzida (abaixo de 50 lux), predominantes no interior do laboratório de manutenção.

\subsection{Animais e condições experimentais}

Um dia após a eclosão, as larvas foram transferidas para recipientes de fibrocimento de 250 litros de capacidade, mantidos em um ambiente com baixa intensidade luminosa $(<50$ lux), onde permaneceram por um período de três semanas. Destes recipientes, chamados de caixas de manutenção, foram retirados os animais que se destinaram para o estudo histológico do trato digestório.

A água utilizada nas caixas de manutenção de $250 \mathrm{~L}$ provinha, por gravidade, de um reservatório elevado, com $4.000 \mathrm{~L}$ de capacidade, onde era armazenada após dupla filtragem em filtros de areia e pedras. Amostras de água das caixas de manutenção de larvas foram coletadas pela manhã e à tarde, duas vezes por semana, para determinação dos valores de algumas variáveis como oxigênio dissolvido (em mg. $\left.\mathrm{L}^{-1}\right), \mathrm{pH}$ (em unidades) e amônia (em mg. $\left.\mathrm{L}^{-1}\right)$. Para as determinações de oxigênio e $\mathrm{pH}$ utilizou-se equipamento portátil HORIBA 
pH/DO Meter D25, enquanto que para amônia empregou-se o método de comparação de cores através do conjunto de reagentes MERCK Microquant 14750. Valores da temperatura da água também foram anotados, três vezes ao dia, utilizando-se termômetro digital DELTA MC-T 102. Para o oxigênio dissolvido, os teores variaram entre 5,7 e $6,5 \mathrm{mg} . \mathrm{L}^{-1}$, correspondendo a aproximadamente 79 e $85 \%$ de saturação, nas temperaturas de $28,0^{\circ} \mathrm{C}$ e $25,0^{\circ} \mathrm{C}$, respectivamente; o pH situou-se entre 7,4 e 7,8, enquanto que os valores de amônia permaneceram abaixo de $0,2 \mathrm{mg} \cdot \mathrm{L}^{-1}$. A temperatura da água oscilou entre $25,0^{\circ} \mathrm{C}$ e $28,0^{\circ} \mathrm{C}$.

As medidas de iluminância (em lux) no interior do laboratório foram realizadas por meio de equipamento apropriado (luxímetro Panlux/Gossen).

As larvas permaneceram em jejum, nutrindo-se apenas das reservas vitelínicas até 3 dias após a eclosão (DPE), após o que foram alimentadas em pulso, três vezes ao dia, com náuplios de Artemia recém-eclodidos, ad libitum.

\subsection{Colheita, fixação e processamento para microscopia óptica}

As amostras foram colhidas com o uso de uma pipeta iniciando-se no $3^{\circ}$ dias após a eclosão. As outras amostras foram obtidas 5, 7, 9, 11, 13 e 16 dias pós-eclosão. Para cada amostra, a colheita foi de quinze exemplares, que foram anestesiados em solução de benzocaína a $0,01 \%$ até a cessação dos movimentos natatórios, imediatamente fixados com solução de Karnovsky (paraformaldeído a 10\%, solução tampão 0,2M - 50 ml, glutaraldeído $25 \%$ - $10 \mathrm{ml}$ e água destilada $-100 \mathrm{ml}$ ) por 24 horas, em seguida substituídas por solução tampão cacodilato de sódio 0,1M em pH 7,4 e acondicionados em refrigerador por 24 horas.

A seguir as larvas de cada amostra foram incluídas em resina histológica “HISTORESIN LKB 2218” utilizando-se o seguinte procedimento: solução alcóolica 95\%, 
por duas horas, resina mais álcool $95 \%$ na proporção de $1: 1$, por quatro horas o material foi colocado em solução com 50\% de resina e 50\% de álcool a 95\% durante 2 horas.

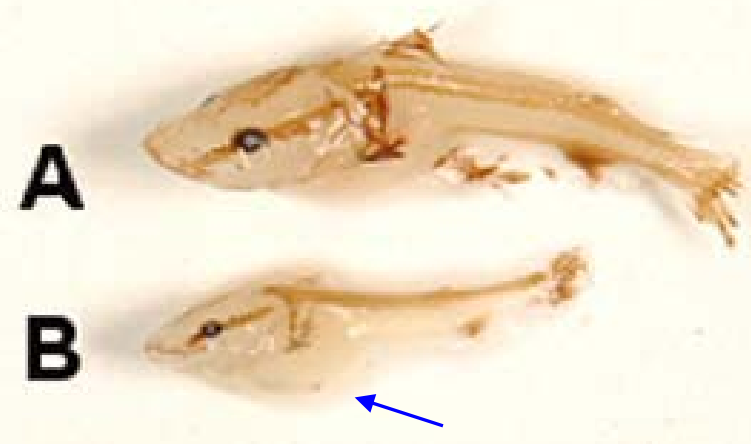

Figura - 1 Vista lateral esquerda de larvas de Pseudoplatystoma coruscans, onde pode ser vista ventralmente a saliência da bolsa intestinal. A- larvas com 13 DPE e em Blarvas com 11 DPE. Barra $=2.0 \mathrm{~cm}$.

Tabela 1 - Informações sobre as larvas de pintado Pseudoplatystoma coruscans mantidas no experimento e utilizadas para estudo da histologia do trato digestório

\begin{tabular}{ccccc}
\hline $\begin{array}{c}\text { Coletas } \\
\text { das } \\
\text { Larvas }\end{array}$ & D.P.E. & Hora (h) & $\begin{array}{c}\text { Temperatura } \mathrm{H}_{2} \mathrm{O} \\
\left({ }^{\circ} \mathrm{C}\right)\end{array}$ & $\begin{array}{c}\text { Comprimento } \\
(\mathrm{mm}) \\
\mathrm{n}^{\mathrm{o}}=15\end{array}$ \\
\hline $1^{\mathrm{a}}$ & $3^{\mathrm{o}}$ & 11 & 26,0 & $5,0 \pm 0,1$ \\
$2^{\mathrm{a}}$ & $5^{\mathrm{o}}$ & 8 & 25,5 & $6,7 \pm 0,1$ \\
$3^{\mathrm{a}}$ & $7^{\mathrm{o}}$ & $10: 30$ & 25,0 & $7,9 \pm 0,1$ \\
$4^{\mathrm{a}}$ & $9^{\mathrm{o}}$ & 9 & 26,5 & $9,0 \pm 0,1$ \\
$5^{\mathrm{a}}$ & $11^{\mathrm{o}}$ & $8: 30$ & 28,0 & $12,2 \pm 0,2$ \\
$6^{\mathrm{a}}$ & $13^{\mathrm{o}}$ & 9 & 27,0 & $17,2 \pm 0,2$ \\
$7^{\mathrm{a}}$ & $16^{\mathrm{o}}$ & $10: 30$ & 27,5 & $22,2 \pm 0,2$ \\
\hline
\end{tabular}


$\mathrm{Na}$ etapa seguinte as amostras foram transferidas para solução de resina $100 \%$ onde permaneceram durante toda noite. Para inclusão do material utilizou-se resina $100 \%$ na qual adicionou-se 1,5 $\mathrm{ml}$ de endurecedor HISTORESIN 501 para cada $15 \mathrm{ml}$ de resina básica.

O preparo da historresina segue o seguinte protocolo: $50 \mathrm{ml}$ de resina básica; onde acrescentou-se o ativador $0,5 \mathrm{~g}$ misturando vagarosamente, até a completa dissolução do mesmo. O emprego desta solução infiltradora também se deu como base do meio de inclusão.

As larvas de cada bloco foram cortadas, em série de 50 secções, com 4 micrômetros de espessura. Para os cortes, utilizou-se um micrótomo semi-automático LEICA RM 2055, empregando facas de vidro descartáveis. Os cortes foram levados a um recipiente contendo água destilada à temperatura ambiente, e colhidas nas lâminas histológicas.

\subsection{Métodos de coloração}

Para detecção de mucopolissacarídeos (glicoconjugados) os cortes foram submetidos às seguintes reações histoquímicas de acordo com (BANCROFT; GAMBLE, 2002):

A) Ácido periódico-reativo de Schiff (PAS) e Hematoxilina como coloração de fundo, para detecção de muco neutro, corando os glicoconjugados neutros em magenta, pela reação do reativo de Schiff com os grupamentos vic-glicóis.

B) Azul de Alcian (AB) a 1\% em ácido acético a 3\% e pH 2,5 empregando-se para contrastar Safranina $\mathrm{O}$ a $0,1 \%$ diluído em 1:3. Esta reação é para a detecção de muco ácido, corando-os em azul intenso. A proporção de muco ácido para muco neutro foi avaliada pela intensidade da coloração obtida.

C) Reação combinada do Azul de Alcian (AB) a 1\% em ácido acético a 3\% e pH2,5. Esta reação é para a detecção de muco ácido, corando-os em azul intenso. Em seguida realizase a reação do Ácido periódico-reativao de Schiff (PAS), para detecção de muco neutro, 
corando os glicoconjugados neutros em magenta, pela reação do reativo de Schiff com os grupamentos vic-glicóis, e coloração violeta representando a associação de ambas as reações.

C) Azul de Toluidina aquosa a $1 \%$ para estudo das estruturas e também corando metacromáticamente o muco ácido e o tecido em vários tons de azul.

Utilizamos para estudo dos cortes histológicos, o microscópio óptico AXIOPLAN 2 ZEISS, do Departamento de Cirurgia do Setor de Anatomia da FMVZ da USP de São Paulo. 


\section{RESULTADOS}

Nas larvas de Pseudoplatystoma coruscans a boca está em posição terminal, na região cranial, encontra-se aberta no $3^{\circ}$ DPE. O restante do trato digestório está diferenciado nos seguintes segmentos: bucofaringe, esôfago, estômago e o intestino. O alimento pôde ser encontrado no estômago e intestino no $3^{\circ}$ DPE. O saco vitelínico pôde ser observado até o $5^{\circ}$ DPE na região abdominal próximo ao fígado, não sendo mais observado nas fases seguintes.

Do $3^{\circ}$ DPE em diante os olhos estavam bem evidentes com bordas oculares delimitadas e notou-se a retina bem pigmentada.

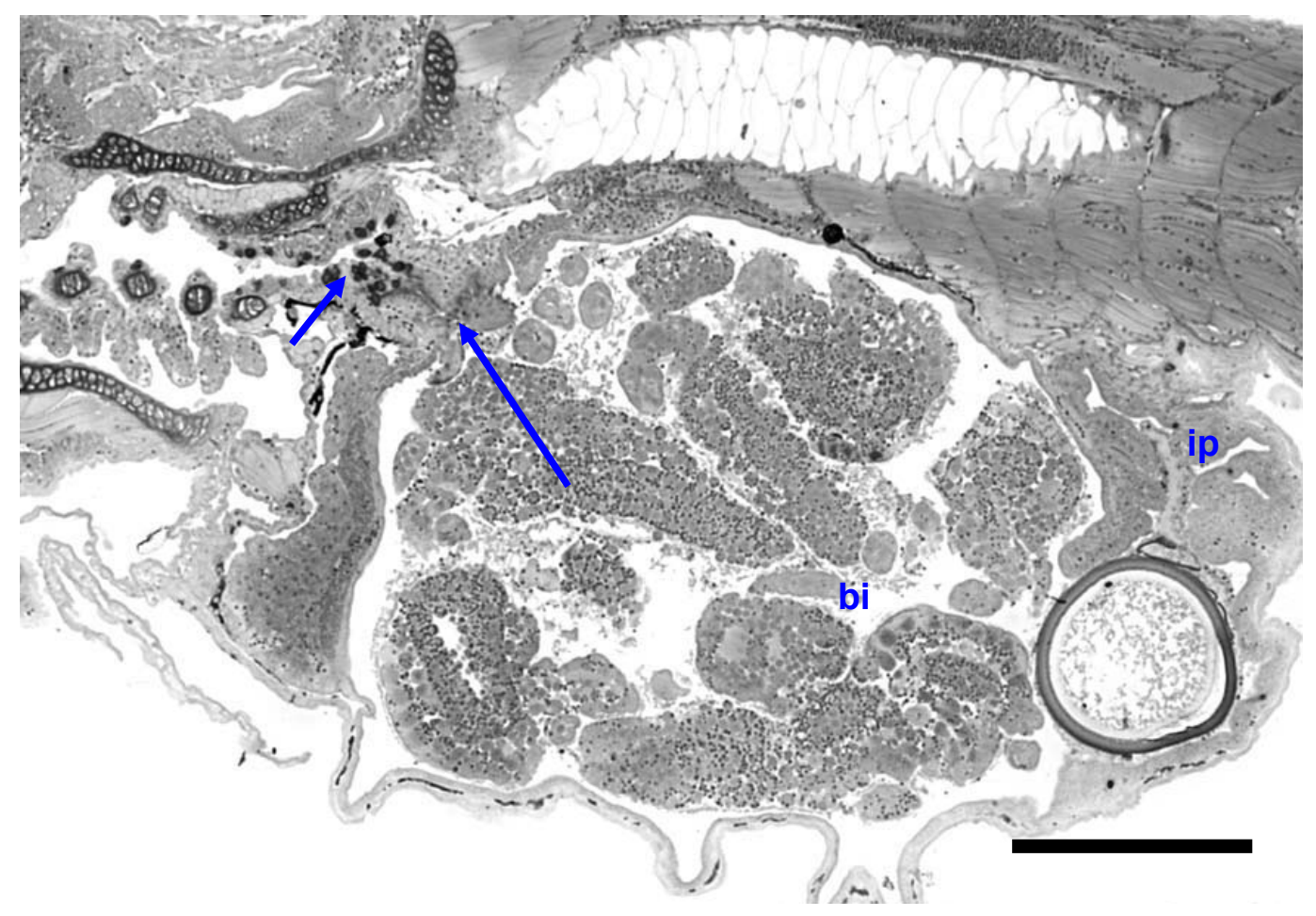

Figura -2 Fotomicrografia ilustrando corte sagital da larva de Pseudoplatystoma coruscans com 5 DPE mostrando região do esôfago com células mucosas (seta curta), primórdio do estômago (seta longa), bolsa intestinal (bi) repleta de alimentos (Artemia nauplii) situada na região ventral do abdome e parte do intestino intestino proximal (ip). Azul de toluidina. Barra $=0.4 \mathrm{~mm}$. 


\subsection{Esôfago}

A partir $3^{\circ}$ DPE, o esôfago da larva de Pseudoplatystoma coruscans é um tubo curto e estreito que conecta a parte caudal do segmento bucofaringeo ao primórdio do estômago, órgão que ainda não está totalmente desenvolvido.

\subsubsection{Mucosa}

O esôfago é revestido por epitélio pavimentoso estratificado, com células mucosas ou secretoras, que deixam de ser visualizadas na região onde inicia-se o primórdio do estômago (Figura 3 e 4). As células mucosas são mais arredondadas quanto mais isoladas ou distantes entre si, e piriformes quanto mais próximas e numerosas. Apresentam um pólo apical delgado que se abre na superfície epitelial por meio um poro. O citoplasma é volumoso em relação ao núcleo, claro e com aspecto vesiculado. Elas assumem a forma de um barril em virtude da parte central se abaular com o acúmulo de grânulos grandes e claros. O núcleo das células mucosas tem perfil baixo em relação ao eixo mais longo da célula, algumas vezes deslocandose para a posição basal. O número de células mucosas ou secretoras aumenta com a idade da larva concentrando-se em direção caudal do esôfago, próximo ao estômago indiferenciado. O muco intracitoplasmático cora-se metacromáticamente com azul de toluidina, sendo positivo com PAS e AB pH 2.5, sendo assim uma mistura de muco neutro e ácido, com a fração de muco ácido predominando (Figura 3). A morfologia do esôfago acima descrita mantém-se até o $7^{\circ} \mathrm{DPE}$.

Do $9^{\circ}$ ao $16^{\circ}$ DPE, o esôfago alonga-se e expande-se em pregas complexas e ramificadas, que são projetadas para o interior de toda luz do órgão. 
A lâmina própria-submucosa é constituída por tecido conjuntivo frouxo que varia apenas em espessura até o $16^{\circ} \mathrm{DPE}$, a qual aumenta progressivamente com a idade da larva.

$\mathrm{Na}$ região de transição com o primórdio do estômago, ocorre abrupta mudança do epitélio pavimentoso estratificado para prismático simples (Figura 3).

\subsubsection{Camada muscular}

Do $3^{\circ}$ ao $7^{\circ}$ DPE foi observada abaixo da lâmina própria, uma túnica muscular composta por uma delgada camada circular de músculo estriado esquelético.

A partir do $9^{\circ} \mathrm{DPE}$, visualizamos abaixo da lâmina própria, duas túnicas delgadas de músculos estriado esquelético, uma túnica circular interna e uma túnica longitudinal externa (Figura 3). A camada muscular do esôfago estende-se até o início do primórdio do estômago, sendo gradualmente substituída pela musculatura lisa neste órgão.

\subsection{Estômago}

O estômago do $3^{\circ}$ ao $9^{\circ}$ dia DPE da larva de Pseudoplatystoma coruscans é um tubo curto e com luz ligeiramente alargada, com parede delgada, onde observam-se dobras na mucosa (Figura 3). A partir do $11^{\circ}$ DPE apresenta uma forma "arredondada" com espessa camada muscular, ocupando marcadamente uma grande região na cavidade abdominal da larva. (Figura 4 e 6 ). 


\subsubsection{Mucosa}

Entre o $3^{\circ}$ e o $9^{\circ}$ DPE a mucosa do estômago distingue-se da mucosa do esôfago por apresentar epitélio prismático simples, de citoplasma basófilo, núcleo arredondado ou alongado, escuro e basal, com nucléolo bem visível e ausência de células mucosas. O citoplasma de cada célula epitelial forma uma saliência ligeiramente abaulada para a luz do órgão, corando-se com muco ácido e neutro. Esta região apresenta-se recoberta por uma película de reação positiva aos glicoconjugados ácidos até o $11^{\circ} \mathrm{DPE}$ (Figura 3 e 4).

Observamos que o muco neutro também aparece no citoplasma apical, em todas as fases observadas.

A partir do $13^{\circ}$ DPE aglomerados de glândulas curtas revestidas por células arredondadas são encontradas na lâmina própria do estômago (Figura 4 C, D e Figura 6 ). O citoplasma dessas células contém pequenos e claros grânulos acidófilos que são negativo à presença de muco quando corados com azul de toluidina, PAS ou AB. As glândulas gástricas tornam-se mais enoveladas conforme evolui o crescimento larva. A luz do estômago aumenta em relação à idade da larva (Figuras $4 \mathrm{C}$ ).

No $16^{\circ}$ DPE a luz gástrica torna-se uma bolsa ampla que contém alimento. A parede do órgão torna-se espessa devido ao aumento na complexidade e espessura da mucosa tomada por numerosas glândulas gástricas: a lâmina própria e o epitélio formam complexas dobras e criptas que entram na lâmina própria (Figura $4 \mathrm{C}$ e D).

As criptas gástricas invaginam-se para o interior de toda região da mucosa do estômago. Em algumas regiões elas são pouco profundas, em outras mais profundas ao longo do estômago, atingindo o máximo de desenvolvimento na região caudal do órgão. Na base das criptas pôde ser observada a abertura de glândulas gástricas (Figura 6), as quais são longas, 
enoveladas e ocupam a maior parte da lâmina própria. $\mathrm{O}$ número de grânulos basófilos aumenta no citoplasma das células glandulares.

No $13^{\circ}$ e $16^{\circ} \mathrm{DPE}$, apenas muco neutro, ou seja, secreção PAS positiva, foi encontrado no epitélio da mucosa do estômago (Tabela 2 e Figura 4 C e D).
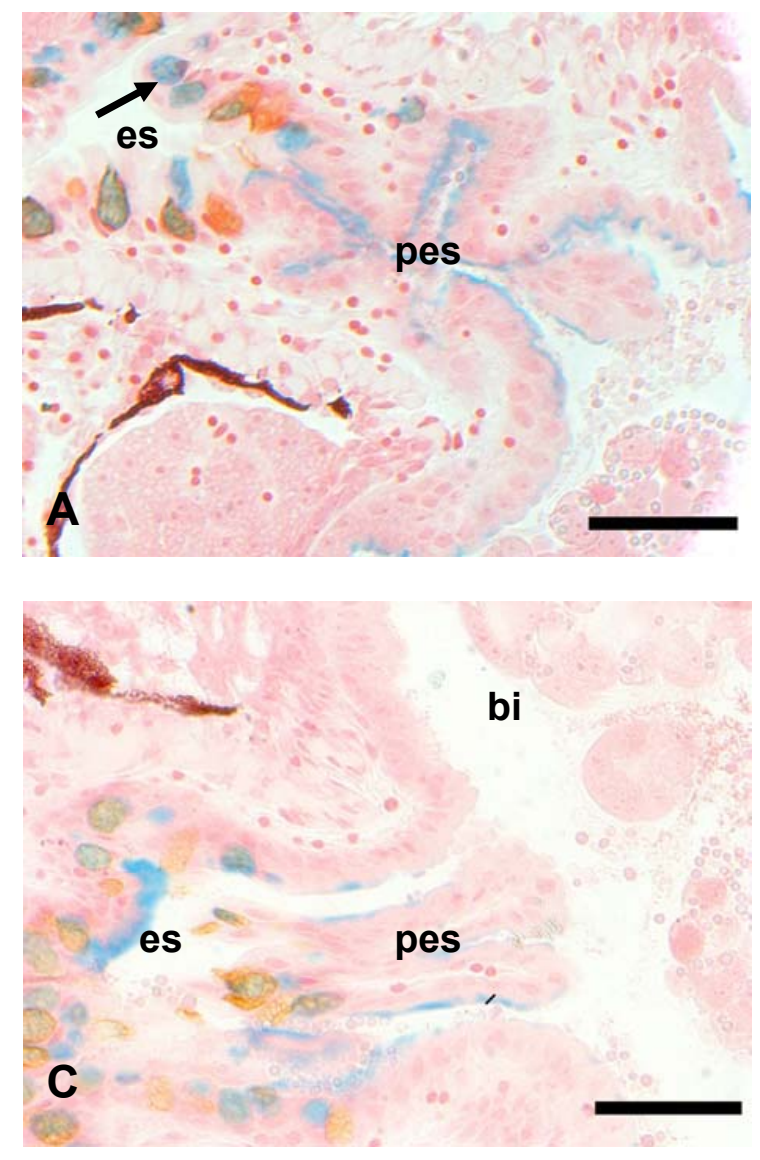
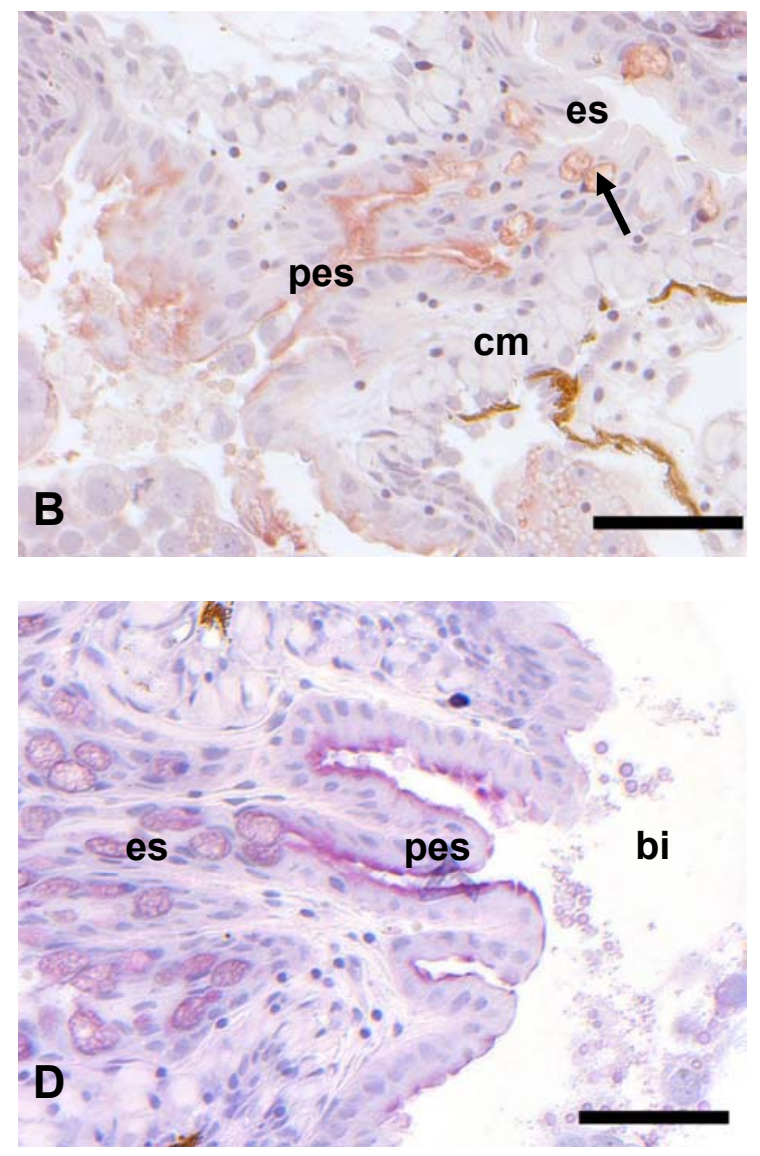

Figura-3 Fotomicrografias em corte sagital da larva de Pseudoplatystoma coruscans ilustrando a região de transição entre o esôfago e o primórdio do estômago. A Larvas no $5^{\circ} \mathrm{DPE}$ evidenciando reação positiva ao $\mathrm{AB}$. Barra $=50 \mu \mathrm{m}$. B - Larvas no $5^{\circ}$ DPE evidenciando reação positiva ao PAS. Barra $=50 \mu \mathrm{m} . \mathbf{C}$ - Larvas no $9^{\circ}$ $\mathrm{DPE}$ evidenciando reação positiva ao $\mathrm{AB}$. Barra $=50 \mu \mathrm{m}$. D - Larvas no $9^{\circ} \mathrm{DPE}$ evidenciando reação positiva ao PAS. Barra $=50 \mu \mathrm{m}$. Observar na região do esôfago (es) a presença de muitas células mucosas ( $\longrightarrow$ ) com aspecto barril e citoplasma repleto de grânulos de secreção. Observar a camada muscular (cm) no esôfago, e no primórdio do estômago (pes) o epitélio prismático simples com núcleo na região basal. Parte da bolsa intestinal (bi) com alimentos (Artemia nauplii). 

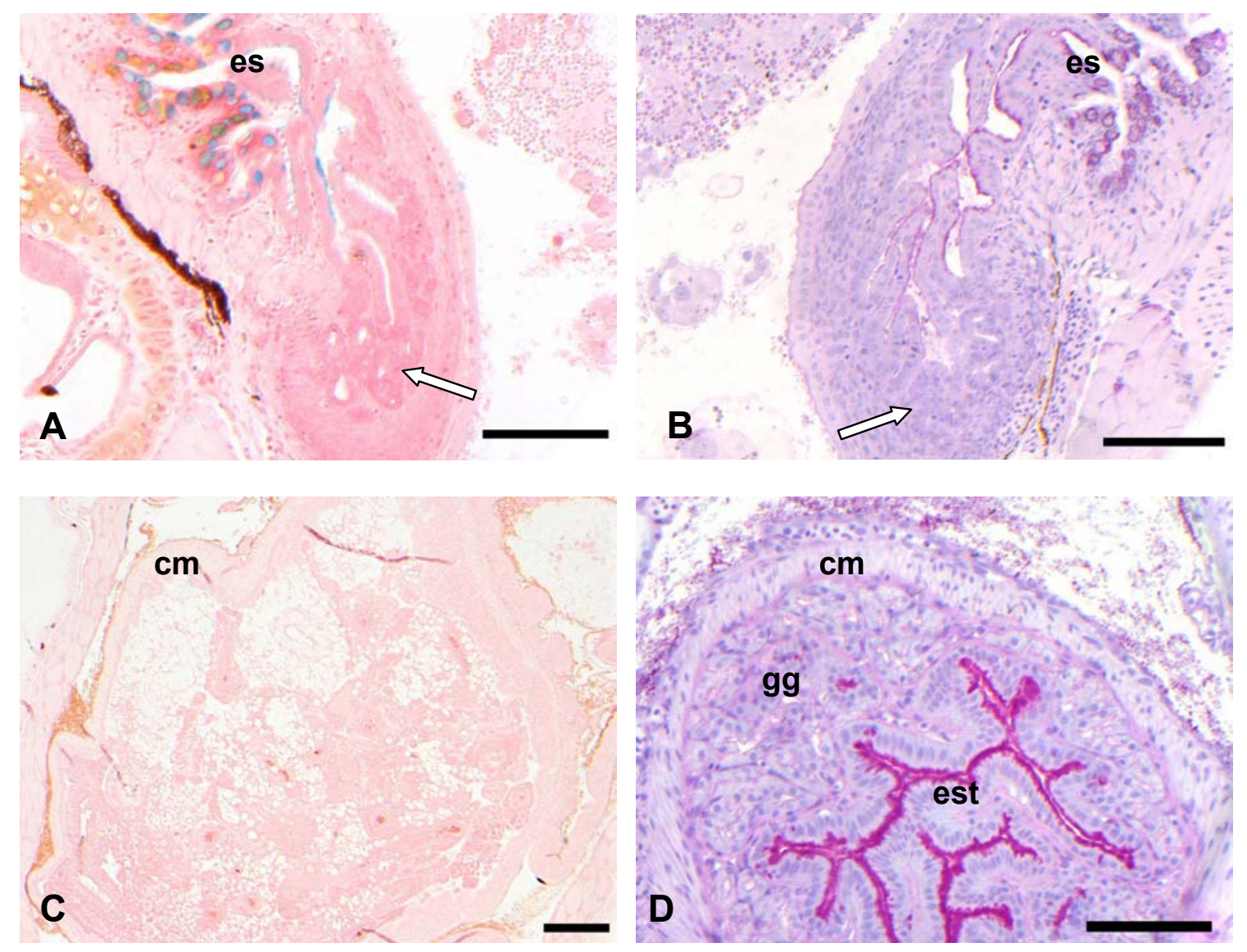

Figura-4 Fotomicrografias ilustrando corte sagital do estômago da larva de Psedoplatystoma coruscans. A - Larvas no $11^{\circ} \mathrm{DPE}$ evidenciando reação positiva ao $\mathrm{AB}$. Barra $=100 \mu \mathrm{m}$. B - Larvas no $11^{\circ} \mathrm{DPE}$ evidenciando reação positiva ao PAS. Barra $=100 \mu \mathrm{m}$. $\mathbf{C}-$ Larvas no $16^{\circ} \mathrm{DPE}$ evidenciando reação negativa ao Alcian blue $\mathrm{pH} 2,5$. Barra $=100 \mu \mathrm{m}$. D - Larvas no $16^{\circ} \mathrm{DPE}$ evidenciando reação positiva ao PAS. Barra $=100 \mu \mathrm{m}$. Luz do estômago (est), camada muscular $(\mathbf{c m})$ e região de glândulas gástricas (gg). No primórdio do estômago (pes) pode-se observar o epitélio prismático simples com núcleo na região basal. Região de glândulas gástricas $\rightleftarrows$ 
Tabela 2 - Intensidade da coloração das células mucossecretoras para o PAS (muco neutro) e Alcian Blue pH 2.5 (muco ácido) no esôfago e estômago de larvas de Pseudoplatystoma coruscans.

\begin{tabular}{|c|c|c|c|c|c|c|c|c|c|}
\hline \multirow[t]{2}{*}{ Órgãos } & \multirow[t]{2}{*}{ Região } & \multirow[t]{2}{*}{ Métodos } & \multicolumn{7}{|c|}{ Dias pós eclosão (DPE) } \\
\hline & & & $3^{\circ}$ & $5^{\circ}$ & $7^{\circ}$ & $9^{\circ}$ & $11^{\circ}$ & $13^{\circ}$ & $16^{\circ}$ \\
\hline \multirow{4}{*}{ Esôfago } & \multirow[b]{2}{*}{ Cranial } & PAS & + & + & + & ++ & ++ & +++ & +++ \\
\hline & & $\mathrm{AB}$ & ++ & ++ & ++ & ++ & ++ & +++ & +++ \\
\hline & \multirow[b]{2}{*}{ Caudal } & PAS & + & + & + & ++ & ++ & +++ & +++ \\
\hline & & $\mathrm{AB}$ & ++ & ++ & ++ & ++ & ++ & +++ & +++ \\
\hline \multirow{2}{*}{ Estômago } & & PAS & + & ++ & ++ & ++ & +++ & ++++ & +++ \\
\hline & & $\mathrm{AB}$ & + & ++ & ++ & ++ & + & - & - \\
\hline
\end{tabular}

\subsubsection{Camada muscular}

A partir do $11^{\circ}$ DPE observamos a camada muscular composta por duas túnicas, estando mais desenvolvidas no $16^{\circ}$ DPE. A camada muscular do estômago das larvas de Pseudoplatystoma coruscans é constituída de musculatura lisa, ao contrário do esôfago, com fibras orientadas circularmente correspondendo à túnica interna e fibras orientadas longitudinalmente correspondendo à túnica externa (Figura 4 ).

\subsection{Intestino}

A transição entre o estômago e o intestino proximal da larva de Pseudoplatystoma coruscans é claramente delimitada por mudança abrupta do tipo de epitélio. O revestimento 
intestinal é formado basicamente por epitélio prismático simples com borda estriada constituído por enterócitos e células caliciformes.

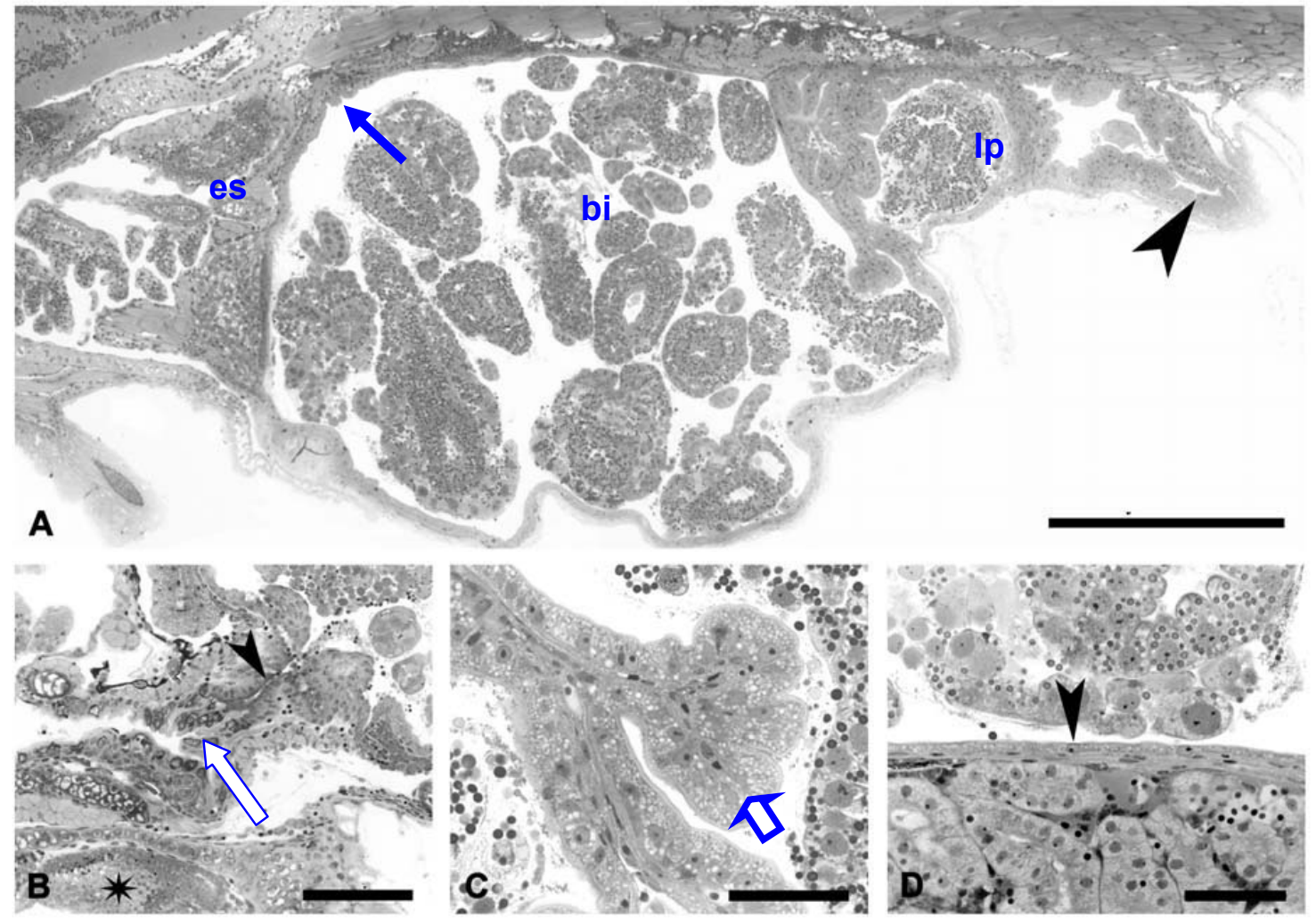

Figura - 5 A- Fotomicrografia ilustrando trato digestório de larvas de Pseudoplatystoma coruscans corada com azul de toluidina. A - Corte sagital em larvas com 7 DPE mostrando esôfago (es), primórdio do estômago ( $\longrightarrow$ ) e bolsa intestinal (bi) situada na região ventral do abdome repleta de alimentos (Artemia nauplii) e também o intestino proximal (ip). O reto é a região onde a ponta de seta indica. Barra $=0.4 \mathrm{~mm}$. B - Larvas no $5^{\circ}$ DPE mostrando a região do esôfago com muitas células mucosas (seta vasada) e primórdio do estômago formado por epitélio colunar onde o muco acumulado sobre a região apical do citoplasma aparece escuro (seta aponta) e parte da bolsa duodenal. Azul de toluidina. Barra= $30 \mu \mathrm{m}$. C - As vesículas nos enterócitos (ponta da seta) provavelmente são gotas de lipídeos em larvas com 9 DPE. Barra $=30 \mu \mathrm{m}$. D - Epitélio cúbico baixo (ponta da seta) da bolsa duodenal. Barra $=30 \mu \mathrm{m}$. 

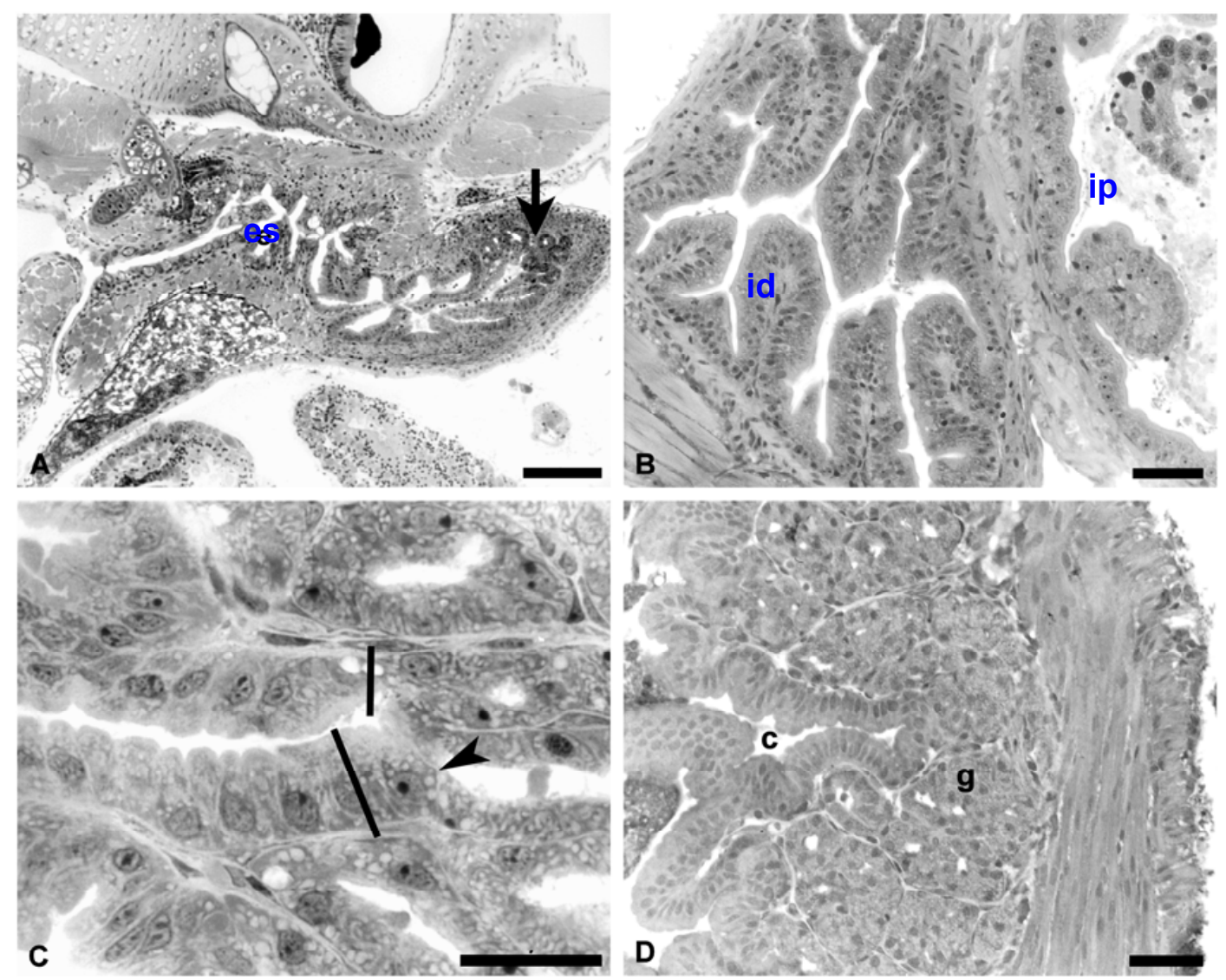

Figura- 6 A- Fotomicrografia ilustrando em corte sagital o trato digestório da larva de Pseudoplatystoma coruscans. A - Esôfago (es) e estômago em larvas no $11^{\circ} \mathrm{DPE}$ onde podem ser observadas as primeiras glândulas gástricas (ponta da seta). Barra $=100 \mu \mathrm{m}$. B - Intestino proximal (ip) e intestino distal (id) em larvas no $13^{\circ} \mathrm{DPE}$ observar a organização das pregas intestinais. O epitélio do intestino distal é mais escuro e menos vacuolizado do que o intestino proximal. Barra $=50 \mu \mathrm{m}$. C Estômago da larva com 13 DPE. Nesta fotomicrografia, as barras mostram a transição entre as criptas (esquerda) e glândulas gástricas (direita). O citoplasma das células oxintopépticas contém grânulos de secreção (ponta da seta). Barra = $20 \mu \mathrm{m}$. D - Estômago da larva no $16^{\circ} \mathrm{DPE}$. Barra $=50 \mu \mathrm{m}$. As criptas (c) e glândulas (g) estão bem definidas. Abaixo das glândulas pode ser observada duas túnicas musculares. 
Em larvas com 3 DPE, é possível identificar duas regiões intestinais distintas: a bolsa intestinal e o intestino proximal. Em larvas com 11 DPE notam-se três regiões intestinais distintas: a bolsa duodenal, o segmento intestinal proximal e o segmento intestinal distal com o reto.

\subsubsection{Bolsa intestinal}

No $3^{\circ}$ DPE a bolsa intestinal é definida externamente por uma evidente saliência anatômica, ocupando uma ampla região do abdômem da larva (Figura 1). Internamente ela apresenta ampla luz arredondada, e entre o $5^{\circ} \mathrm{DPE}$ e o $13^{\circ} \mathrm{DPE}$, ela se mantém repleta de alimentos porém seu volume se reduz por volta do $16^{\circ}$ DPE. A bolsa intestinal é constituída principalmente por epitélio de revestimento cúbico próximo ao primórdio do estômago, alterando seu aspecto para cúbico baixo na região dorsal, caudal e ventral da bolsa. (Figura 2 e 5).

A partir do $3^{\circ}$ DPE nota-se neste epitélio, uma borda luminal proeminente e espessa a qual é chamada de borda ou cutícula estriada. Estas células também são conhecidas por células absortivas ou enterócitos por apresentar características morfofisiológicas de células que absorvem nutrientes. O núcleo é arredondado, grande e claro situa-se mais próximo da região basal e ainda com um nucléolo evidente em sua periferia. Seu citoplasma é caracterizado por grandes, nítidas e numerosas vesículas claras. Esse aspecto celular é mantido até o $16^{\circ} \mathrm{DPE}$.

Entre o $3^{\circ}$ e $16^{\circ}$ DPE, observamos entremeadas entre os enterócitos da bolsa intestinal, ocasionais células caliciformes. Elas assumem a forma de um cálice em virtude da parte central se abaular com o acúmulo de vesículas de secreção. Neste período verificamos que as células caliciformes apresentam muco ácido ou neutro, ou ainda, ambos simultaneamente. 
A partir do $9^{\circ}$ DPE, algumas regiões da mucosa da bolsa intestinal, dobram-se para o interior de sua luz formando pregas que são preenchidas na parte central com tecido conjuntivo frouxo. Notou-se uma fina e descontínua camada muscular de músculo liso revestindo externamente a região dorsal da bolsa.

\subsubsection{Intestino proximal}

No $3^{\circ}$ DPE o segmento proximal do intestino da larva é definido com um aspecto tubular de estreita luz. Ele inicia-se caudalmente à bolsa intestinal. Seu revestimento é semelhante ao da bolsa intestinal, porém o epitélio é prismático simples em toda a extensão. O núcleo dos enterócitos neste segmento é esférico, encontra-se localizado na região central, apresentando um nucléolo marcadamente deslocado para a periferia.

Em todas as idades observadas, as regiões supra e infra-nucleares do citoplasma dos enterócitos apresentaram-se preenchidas com numerosas e grandes vesículas, semelhantes às do epitélio da bolsa intestinal (Figura 7A e B). Identificamos uma camada na região subapical

intracelular formada por grânulos basófilos pequenos (Figura 7B). Notou-se que os enterócitos do ápice das pregas são mais vesiculados que os da base e os laterais.

Observou-se a presença de células caliciformes entre o $3^{\circ}$ DPE e o $16^{\circ} \mathrm{DPE}$, porém foram notadas com mais freqüência a partir do $11^{\circ}$ DPE. Elas estão dispersas tanto no ápice, quanto nas laterais e base das pregas da mucosa. Esse aspecto epitelial da mucosa intestinal, mantém-se até $16^{\circ} \mathrm{DPE}$.

As pregas nesta região aumentam sua freqüência sem forma definida, isto é, às vezes são ramificadas, altas e espaçadas; às vezes são baixas e sem ramificações. Os sulcos entre as pregas da mucosa são marcadamente profundos e largos. O centro das pregas intestinais é 

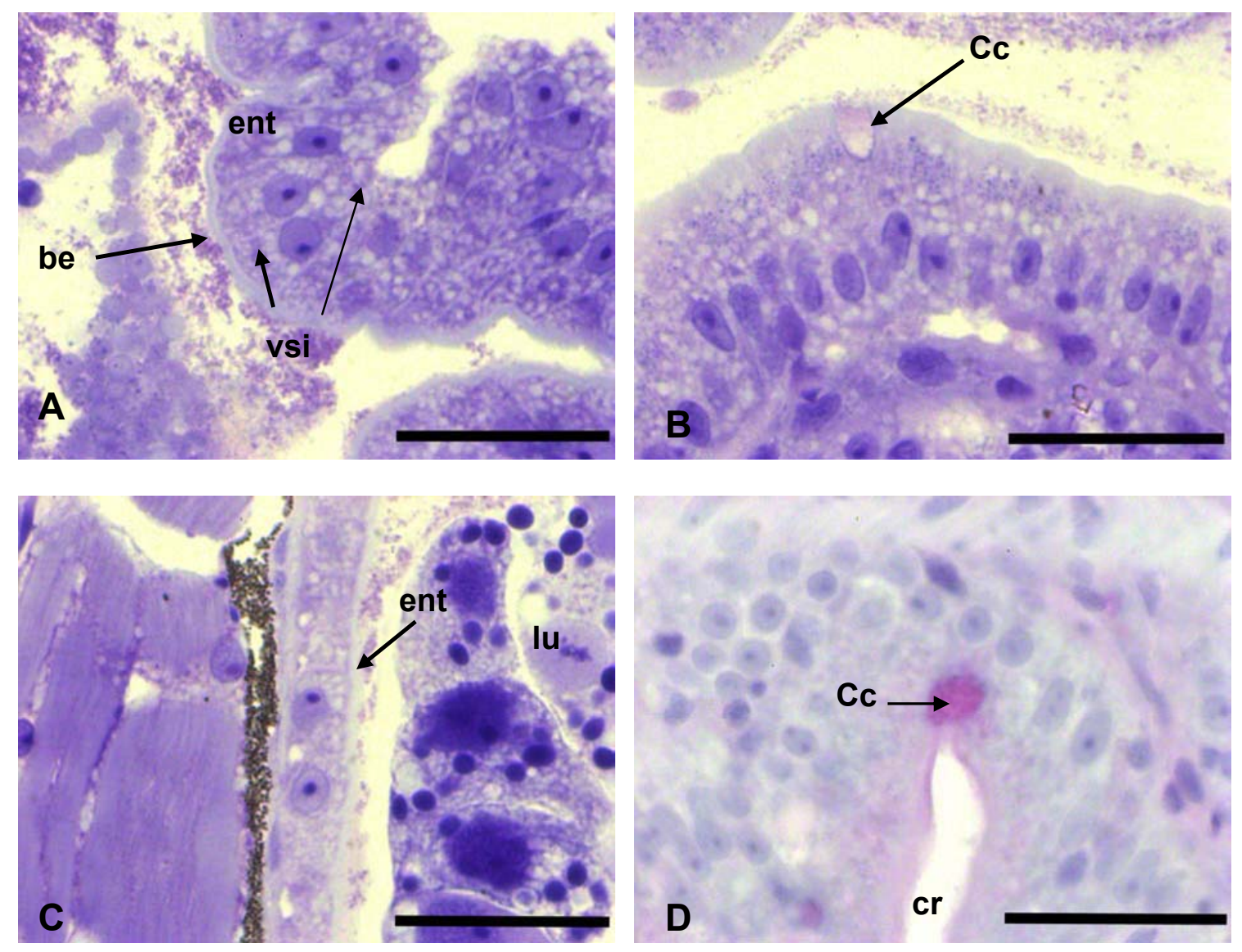

Figura - 7 Fotomicrografias ilustrando em corte sagital do intestino da larva de $P$. coruscans no $11^{\circ}$ DPE. A - Segmento proximal do intestino. Epitélio cilíndrico absortivo com enterócitos (ent) mostrando borda estriada (be) bem desenvolvida e citoplasma repleto de vesículas supra e infranucleares (vsi). Azul de toluidina. Barra $=50 \mu \mathrm{m}$. B - Outra região do intestino proximal mostrando célula caliciforme $(\mathbf{C c})$ no topo da prega evidenciando muco ácido. Observar núcleo na região basal da célula. Azul de toluidina. Barra $=50 \mu \mathrm{m}$. $\mathbf{C}-$ Enterócitos (ent) na região dorsal da bolsa intestinal. Observar borda estriada (be) e o epitélio com forma cúbico baixa. Azul de toluidina. Barra $=50 \mu \mathrm{m}$. D - Célula caliciforme $(\mathbf{C c})$ no fundo da cripta (cr) no intestino distal, evidenciando reação positiva ao PAS. Luz (lu) Barra $=50 \mu \mathrm{m}$.

ocupado por tecido conjuntivo frouxo. Observamos que a túnica muscular lisa neste segmento é fina, porém composta por uma camada circular interna e uma camada longitudinal externa.

Notou-se a partir do $11^{\circ}$ DPE e principalmente no $13^{\circ}$ DPE, que a parte caudal do intestino proximal apresentou algumas características epiteliais que nos permitiram diferenciar uma nova região, o intestino distal. 


\subsubsection{Intestino distal}

No $11^{\circ}$ DPE notou-se um segmento intestinal com aspecto tubular de luz estreita, com característica epiteliais que o diferenciam do intestino proximal. Este foi denominado como segmento distal do intestino da larva. Os enterócitos possuem núcleo alongado e situa-se na região basal da célula. O citoplasma também é muito vesiculado porém com vesículas menores, sendo mais basófilo do que o citoplasma dos enterócitos da bolsa e da região proximal, portanto os enterócitos aparecem escuros à observação microscópica com azul de toluidina. A borda estriada dos enterócitos nesta região, também é espessa. Entre $11^{\circ} \mathrm{DPE}$ e o $16^{\circ}$ DPE este segmento torna-se mais alongado e enovelado. Neste período, as células caliciformes entremeadas com os enterócitos são encontradas com maior freqüência e são identificadas dois tipos pela natureza química do muco secretado: uma que produz principalmente muco neutro e outra que produz principalmente muco ácido. A partir do $3^{\circ}$ DPE as pregas da mucosa intestinal distal tornam-se mais complexas e bem próximas uma das outras, ou seja, diminuindo o espaçamento entre elas e seguindo uma padronização em altura e largura (Figura 8).

Ao $16^{\circ} \mathrm{DPE}$, foi observada que a túnica muscular lisa é estreita, sendo composta por uma camada circular interna e uma camada longitudinal externa.

\subsubsection{Segmento retal}

$\mathrm{O}$ reto pode ser observado a partir do $3^{\circ} \mathrm{DPE}$ como um segmento curto final do intestino. O revestimento epitelial é feito por enterócitos de borda estriada menos espessa, comparado ao segmento anterior. O núcleo dos enterócitos apresenta-se alongado em relação ao eixo mais longo da célula, localizando-se na região basal. Seu citoplasma apresenta muitas 

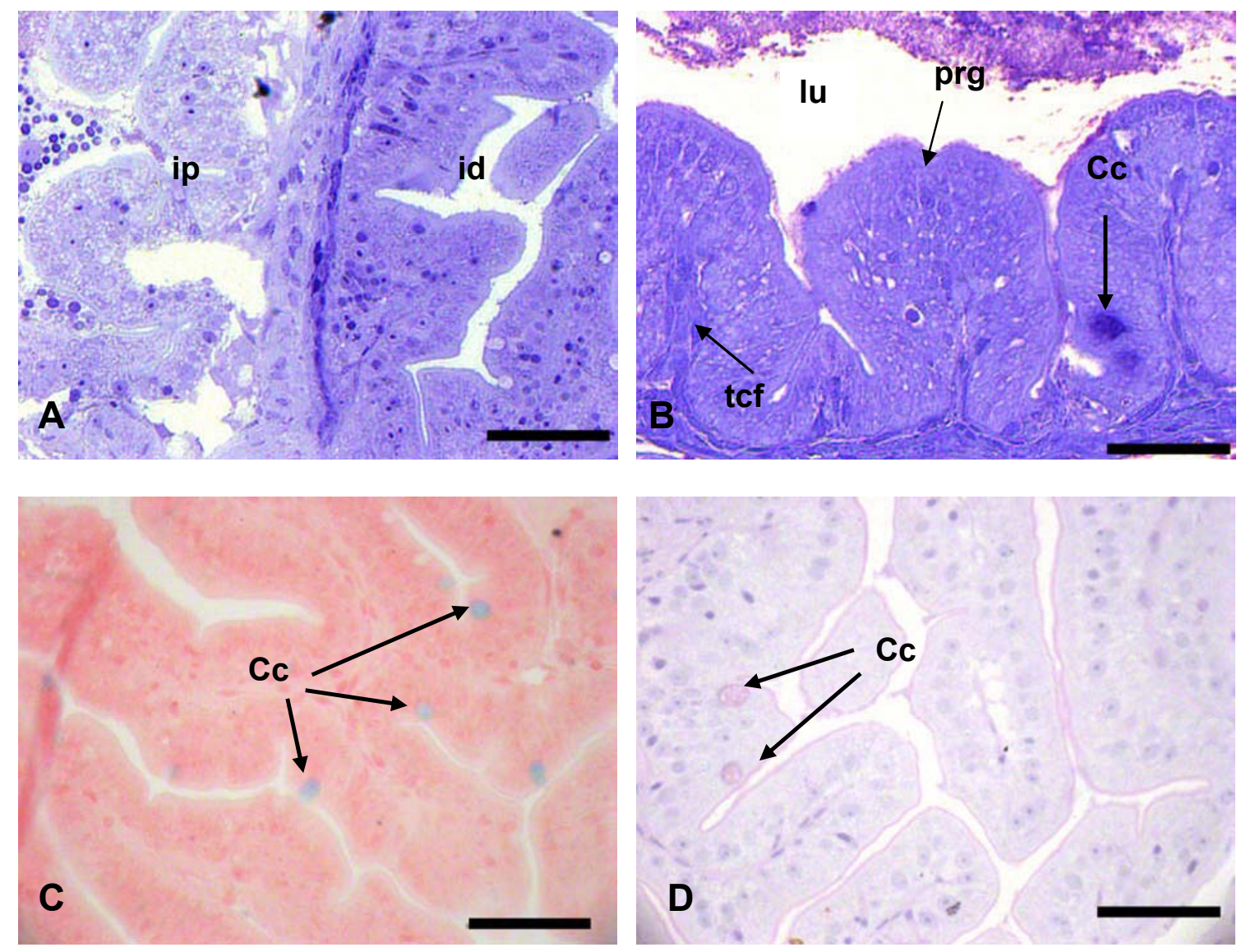

Figura - 8 Fotomicrografias ilustrando intestino da larva de P. coruscans. A- Corte sagital das pregas em uma região do intestino proximal (ip)e do intestino distal (id), em larvas no $7^{\circ} \mathrm{DPE}$. B- Corte sagital mostrando destalhes das pregas (prg) no intestino distal em larvas com $7^{\circ}$ DPE. Observar tecido conjuntivo frouxo (tcf) C- Corte transversal da região do intestino distal de larvas no $11^{\circ} \mathrm{DPE}$, mostrando pregas intestinais (pre) e células caliciformes $(\mathbf{C c})$, evidenciando reação positiva ao Alcian Blue. D - Corte transversal da região do intestino distal em larvas no $11^{\circ} \mathrm{DPE}$ mostrando pregas intestinais e células caliciformes evidenciando reação positiva ao PAS. Luz (lu). Barra $=50 \mu \mathrm{m}$.

minúsculas e nítidas vesículas na região supranuclear. Neste segmento do intestino, o muco neutro está presente em todas as fases observadas.

O reto ressalta-se por apresentar pregas longitudinais, em maior número e mais pronunciadas em todas a fases observadas (Figrua 5). O centro das pregas também é ocupado com tecido conjuntivo frouxo. 


\section{DISCUSSÃO}

A estrutura histológica do trato digestório do P. coruscans é, no aspecto geral, semelhante à de outras larvas de peixes teleósteos, contudo apresenta algumas características peculiares.

As larvas de $P$. coruscans com 3 DPE, apresentam como diferenciação morfológica, a abertura da boca e órgãos do trato digestório independente necessários para a alimentação exógena. Possivelmente a capacidade funcional do trato digestório está relacionada às características da composição do revestimento epitelial.

Estudos histológico e histoquímico da ontogenia do trato digestório do P.coruscans raramente são encontrados na literatura. Santos e Godinho (1994) relataram somente a anatomia da larva, enfocando principalmente o período de vida entre o $1^{\circ} \mathrm{DPE}$ ao $4^{\circ} \mathrm{DPE}$, e observam que a larva já tinha a boca aberta no $2^{\circ}$ DPE. A ingestão de alimento nos primeiros dias de vida é um fato comum em várias espécies de peixes tropicais e temperados (BOULHIC; GABAUDAN, 1992; BISBAL, 1995; RIBEIRO; SARASQUETE; DINIS, 1999; WALFORD; LAN, 1993), fato confirmado em P. coruscans, visto que encontramos alimento no intestino das larvas já no $3^{\circ} \mathrm{DPE}$.

Observamos que no $5^{\circ} \mathrm{DPE}$, o saco vitelínico das larvas de pintado, ainda estava presente e seu trato pronto para ingerir (cavidade bucal está formada e aberta) para transportar (esôfago), armazenar (na bolsa duodenal), absorver alimentos (intestino está desenvolvido) e eliminar os alimentos. Entre o período do $3^{\circ} \mathrm{DPE}$ ao $7^{\circ} \mathrm{DPE}$, ocorre uma mistura na forma de alimentação, durante o qual as larvas nutrem-se de fonte endógena e exógena. O achado de abundante alimento no trato digestório principalmente na bolsa duodenal em um momento na qual a larva ainda tem reservas nutritivas endógenas abundantes pode parecer intrigante, tendo em conta que seu sistema digestório ainda é pouco diferenciado e possivelmente pouco 
eficiente em relação ao volume de alimento encontrado. Foi observado, neste experimento, que o alimento eliminado pelas larvas encontravam-se pouco digerido. Deve-se levar em conta que a larva busca capturar alimento, atividade que dispende alta quantidade de energia. Contudo este período pode ser importante para os animais treinarem captura de presas e estimular as adaptações do trato digestório e o metabolismo energético para alimentação exógena. Reforça esta conclusão o fato de que foi observado em Morone saxatilis, que larvas alimentadas com artemia viva consumiam o lipídio do saco vitelínico mais rapidamente que larvas desnutridas (ELDRIDGE et al., 1983). Os cinco primeiros dias de alimentação exógena são também críticos para a sobrevivência da larva de peixe. Depois deste período, larvas que nunca tiveram um contato anterior com alimento exógeno, geralmente rejeitam o alimento que lhe é oferecido (DOU et al., 2002).

O esôfago, cuja principal função é conduzir o alimento até o estômago, em larva de pintado tem dobras longitudinais nas mucosas, alcançando a complexidade máxima no $11^{\circ}$ DPE. Essas dobras que se desenvolvem durante o crescimento da larva do pintado, provavelmente permitem a distensão durante a deglutição, e ainda, aumentam a superfície de contato com o alimento, conforme também sugerido por outros autores (FERRARIS; TAN; CRUZ, 1987; MURRAY; WRIGHT; GOFF, 1994).

As células mucosas foram encontradas no $3^{\circ} \mathrm{DPE}$. A presença precoce dessas células no esôfago das larvas de pintado, sugere que o esôfago está morfologicamente preparado para se proteger contra a ação abrasiva de alimentos logo no $3^{\circ}$ DPE. As células mucosas produzem muco que lubrifica a superfície do órgão, protegendo-o contra abrasão e lesão no epitélio provocada pela passagem de alimentos (ANDERSON, 1986; GALVÃO et al., 1997; GODINHO, 1970). O epitélio pavimentoso estratificado do esôfago associado à secreção abundante de muco proporciona proteção adicional contra o atrito de alimentos com alto poder abrasivo, como ocorre na espécie adulta de Prochilodus scrofa, onde a alimentação é 
constituída de lodo e organismos ricos em sílica como as algas Diatomae (HERNANDEZBLAZQUEZ, 1986). Observou-se também que o mesmo ocorre em juvenil e adulto de Mugil platanus, cuja alimentação é constituída basicamente de Bacillariophyceae (diatomáceas) e detritos (OLIVEIRA; SOARES, 1996). O muco secretado pelas células mucosas também ajuda na adesão entre as partículas de alimento, unindo-as, para facilitar o seu transporte no trato digestório (CHAUDRY; KHANDELWAL, 1961). O muco carboxilado que caracteriza esta mucosa é mais eficiente que o muco neutro, na proteção mecânica do epitélio dos peixes adultos (REIFEL; TRAVILL, 1977). Assim, o achado de células mucosas no esôfago, secretando muco ácido, pode refletir a necessidade da larva em produzir um muco aglutinante para capturar e agregar as presas minúsculas e ao mesmo tempo proteger a mucosa.

O primórdio do estômago foi identificado no $3^{\circ}$ DPE na larva de pintado pelo tipo de secreção do muco e pelo revestimento epitelial com células prismáticas apresentando o núcleo na região basal e citoplasma apical abaulado. Essa descrição é típica do estômago de teleósteos (KAPOOR; SMIT; VERIGINA, 1969; GRIZZLE; CURD, 1978; BRAGANÇA, 1992). Entretanto, glândulas gástricas com células granulares acidófilas cúbicas, somente foram encontradas na lamina própria após o $11^{\circ} \mathrm{DPE}$.

É conhecido o fato de que glândulas gástricas de teleósteos são constituídas por apenas um tipo de célula. Semelhantes às células oxintopépticas do estômago das aves, as células glandulares gástricas do peixe secretam ambos os produtos envolvidos na hidrólise do alimento: as enzimas e o ácido clorídrico (BANKS, 1992; FERRI; HERNANDEZBLAZQUEZ, 1984; GÁS; NOAILLAC-DEPEYRE, 1978; GOVONI; BOEHLERT; WATANABE, 1986; KAPOOR; SMIT; VERIGHINA, 1975b; MURRAY; WRIGTH; GOFF, 1994a; OSMAN; CACECI, 1991; PEÑA et al., 2003; TUE, 1983).

A idade na qual as glândulas gástricas desenvolvem-se varia com a espécie de peixe. Em Clarias lazera, o corpo do estômago é formado no $4^{\circ} \mathrm{DPE}$ e as primeiras glândulas 
gástricas aparecem no $12^{\circ}$ DPE (STROBAND; KROON, 1981a). Verreth et al. (1993) mostraram em Clarias gariepinus que a secreção gástrica começa no $4^{\circ} \mathrm{DPE}$. Um dia após o $\mathrm{pH}$ do lúmen, esta abaixo de 3,3. Em Acipenser as glândulas gástricas aparecem no $6^{\circ} \mathrm{DPE}$ (GISBERT et al., 1998), no $27^{\circ}$ DPE em senegalenis (RIBEIRO; SARASQUETE; DINIS, 1999; SARASQUETE; POLO; YÚFERA, 1995), entre $29^{\circ}$ DPE e $36^{\circ}$ DPE no Pleuronectes ferruginea (BAGLOLE et al., 1997), no 30 DPE em Sparus auratus (SARASQUETE; POLO; YÚFERA, 1995), no $38^{\circ}$ DPE em Mugil platanus (GALVÃO et al., 1997) e no $42^{\circ}$ DPE em Chanos chanos (FERRARIS; TAN; DE LA CRUZ, 1987). O desenvolvimento glandular gástrico significa o fim do período larval e a mudança do processo digestivo, o qual torna-se progressivamente similar ao do peixe adulto (BOULHIC; GABAUDAN, 1992). De fato o surgimento das glândulas gástricas no estômago da larva é um significativo evento na criação de peixes.

A larva de peixe sem um estômago funcional é conhecida por ter um mecanismo digestivo imaturo, principalmente em que diz respeito à digestão de proteínas. A secreção glandular digere proteínas mais eficientemente que a digestão intracelular das proteínas nos enterócitos, processo este que ocorre normalmente antes da larva desenvolver um estômago (GOVONI; BOEHLERT; WATANABE, 1986). Desta forma, a ausência deste órgão é um problema para a formulação do alimento artificial na alimentação da larva (SEGNER et al., 1993). Isto é importante para mudar a dieta da larva, assim que possível, de presas vivas para alimentos formulados (ração) porque o alimento artificial é menos caro, sua composição pode ser precisamente regulada para as necessidades especificas do peixe e é mais fácil de ser armazenado. A questão critica é quando substituir um tipo de alimentação por outro.

Várias evidências apontam para uma estreita relação entre o desenvolvimento de um estômago funcional e sobrevivência da larva com uma dieta utilizando alimento formulado (ração). As larvas que têm um estômago funcional antes do surgimento da nutrição exógena, 
como em salmonideos, estão mais propensas à adaptar-se ao alimento formulado, já aquelas sem estômago, não crescem bem quando alimentadas com dietas formuladas (ração) (DABROWSKI, 1984; BAGLOLE et al., 1997).

A diferenciação do estômago define-se com o aparecimento de células oxintopépticas. Este evento é considerado um marco no desenvolvimento larval, por permitir o início da digestão de dieta artificial, considerando com isso, o mais confiável método para verificar se a larva de peixe pode digerir alimento formulado (BAGLOLE et al., 1997; GORDON; HECHT, 2002; PEÑA et al., 2003; SEGNER et al., 1993). Nossos resultados revelam que há um período de seis dias, isto é, entre o $11^{\circ} \mathrm{DPE}$ e o $16^{\circ} \mathrm{DPE}$ da vida da larva de pintado, durante o qual as glândulas do estômago sofrem aumento na complexidade. Contudo é difícil dizer apenas pela observação morfológica das glândulas gástricas, exatamente quando a secreção luminal seria ácida suficiente para realizar uma digestão enzimática eficiente. Entretanto, uma evidência da acidificação do suco gástrico pôde ser deduzida pela mudança na histoquímica do muco na superfície do epitélio, de ácido carboxilado para exclusivamente muco neutro, como foi encontrado no $13^{\circ}$ DPE da larva pintado. A intensificação da secreção de muco neutro no estômago, a redução e desaparecimento da secreção de muco ácido com o concomitante desenvolvimento de glândulas gástricas no $13^{\circ} \mathrm{DPE}$ na larva de pintado são marcos importantes devido ao possível impacto fisiológico da associação destes três fatos no processo digestivo.

Em mamíferos, o muco neutro é típico do epitélio do estômago, e é o único muco na superfície do epitélio, agindo como uma barreira protetora contra o ácido clorídrico (ALLEN, 1989). O muco neutro é, então, alcalinizado pela secreção de íons bicarbonato transportados pelos capilares fenestrados que ascendem ao longo das glândulas gástricas e que passam abaixo do revestimento epitelial, aumentando a proteção da mucosa contra autodigestão pela alcalinização do muco (ALLEN et al., 1993). Isto sugere que a presença de muco neutro no 
estômago de larvas de pintado, poderia ser considerada como uma indicação de que o animal está realizando uma digestão gástrica do alimento, estando assim, pronto para aceitar alimento formulado a partir do $13^{\circ} \mathrm{DPE}$ em diante. Experimentos onde alimento formulado foi dado à larva de pintado antes deste período, resultaram em taxa de mortalidade de 100\% (LOPES et al., 1996).

Após o $16^{\circ}$ DPE o volume do estômago do pintado aumenta enquanto o tamanho da bolsa intestinal intestinal diminui. $\mathrm{O}$ órgão então assume a função de armazenagem que foi anteriormente exercida pela bolsa duodenal. Neste período a parede gástrica está composta de uma túnica muscular espessa que pode promover movimentos misturando os alimentos, desta forma ajudando a digestão enzimática.

A bolsa intestinal é encontrada na larva de pintado entre o $3^{\circ} \mathrm{DPE}$ e o $16^{\circ} \mathrm{DPE}$ podendo ser confundida, na primeira semana de vida, com o estômago através da observação macroscópica, provavelmente devido ao grande volume de sua luz e a evidente saliência anatômica externa na região abdominal da larva.

Observamos que a maior parte do alimento oferecido na primeira semana foi eliminado praticamente inteiro indicando uma digestão pouco eficiente. A ingestão de um grande número de presas vivas além da presença do saco vitelino, pode fornecer as necessidades nutricionais para o crescimento da larva, compensando a pouca eficiência do fluxo digestivo nas fases iniciais.

Observou-se no $3^{\circ}$ DPE que o epitélio da bolsa intestinal já está absorvendo nutrientes, como pôde ser deduzido pela presença das vesículas intracelulares claras nos enterócitos. Vesículas semelhantes foram encontradas em outras espécies de larvas, sendo consideradas de fato como gotículas de lipídios (IWAI, 1969; GISBERT et al., 1998; GORDON; HECHT, 2002; RIBEIRO; SARASQUETE; DINIS, 1999). O aspecto e a natureza polimórfica das vesículas aqui encontradas, são parecidas com as gotículas de lipídios vistas nos enterócitos 
de peixes adultos (HERNANDEZ-BLAZQUEZ; SILVA, 1998), o que provavelmente significa que há uma intensa atividade absortiva de lipídeos, nesta região do intestino, nos nove primeiros dias da larva.

Após o $11^{\circ}$ DPE a absorção de lipídios torna-se mais restrita ao intestino proximal. A função de absorção do conteúdo lipídico torna-se assim um dos principais atributos do intestino proximal, sendo uma característica comum nas larvas de teleósteos (BISBAL; BENGTSON, 1995; BOULHIC; GABAUDAN, 1992; SARASQUETE; POLO; YÚFERA, 1995; SIRE; VERNIER, 1992). Uma borda estriada bem desenvolvida na membrana apical dos enterócitos, também indica intenso processo absortivo na bolsa duodenal, e em outros segmentos do intestino da larva. A camada subapical com pequenos grânulos basófilos encontrada entre as grandes vesículas nos enterócitos do intestino proximal, são semelhates as vesículas pinocíticas observadas em outras larvas de teleósteos, sugerindo desta forma, uma região onde ocorre o processo de pinocitose.

É interessante notar que, nos primeiros dias de vida as gotículas intracelulares são encontradas em toda a extensão do intestino, diminuindo a intensidade no curto segmento retal. Isto mostra que a maioria do trato intestinal é direcionada para a absorção de nutrientes, especialmente de lipídeos.

Ao $9^{\circ}$ DPE podem ser observadas dobras na mucosa em algumas regiões da bolsa intestinal. Estas ajudam a aumentar a superfície absortiva e misturar o alimento com as enzimas pancreáticas (GRAU et al., 1992). A freqüência de células caliciformes é maior após o $13^{\circ}$ DPE, secretando muco neutro, ácido ou a mistura dos dois. Ambos os fenômenos podem ser atribuídos ao aumento de alimento ingerido e às mudanças dos processos digestivos devido ao início da função gástrica, como é descrita em outras espécies (BOULHIC; GABAUDAN, 1992; BAGLOLE et al., 1997; RIBEIRO; SARASQUETE; DINIS, 1999, SARASQUETE; POLO; YÚFERA, 1995). Para Anderson (1986), a ocorrência 
de muco no trato gastrointestinal ajuda na lubrificação do alimento favorecendo a sua passagem e provavelmente fornecendo ainda co-fatores necessários para a degradação enzimática do alimento.

O citoplasma dos enterócitos no intestino distal após o $11^{\circ} \mathrm{DPE}$ é mais uniforme, mais escuro e menos vacuolizado, quando comparado com o epitélio do intestino proximal. A espessa borda estriada epitelial e as dobras da mucosa apontam para uma grande atividade absortiva nesta região, a qual pode refletir a especialização na digestão intracelular de proteínas. Alguns autores descreveram na região apical das células absortivas em larva de peixes, vesículas digestivas ou inclusões pinocíticas densas (BAGLOLE et al., 1997; RIBEIRO; SARASQUETE; DINIS, 1999; WATANABE, 1981, 1984). Embora densas inclusões não fossem presenciadas no intestino distal do pintado, a pinocitose de proteína pode também ocorrer por meio de pequenas vesículas, como em alguns peixes (HERNANDEZ - BLAZQUEZ; SILVA, 1998). A especialização regional na absorção intestinal, com o intestino proximal envolvido em absorção de lipídios e o médio e o distal envolvidos em pinocitose de proteína, é comumente encontrado em peixes adultos (NOILLAC-DEPEYRE; GÁS, 1979; SIRE; VERNIER, 1992; STROBAND; KROON, 1981).

Contudo, para a distinção mais precisa entre as diferentes regiões e outros tipos celulares no intestino das larvas de Pseudoplatystoma coruscans, são necessários estudos mais elaborados como o da ultra-estrutura, os histofisiológicos e os histoquímicos, que podem permitir a diferenciação, com total clareza, entre as áreas de absorção de gorduras, absorção de proteínas e absorção de água e íons. 


\section{CONCLUSÃO}

Nossos resultados mostram que:

1- Do $13^{\circ}$ DPE em diante, o estômago e o intestino da larva do Pseudoplatystoma coruscans (pintado) sofrem uma série de importantes modificações. Como um todo, elas indicam que o estômago está encarregando-se da tarefa de armazenar alimentos e digeri-los pelos processos químico e enzimático. Este material digerido é encaminhado para o intestino, que é regionalmente diferenciado e pronto para absorver os nutrientes.

2- A adaptação gástrica no fim da segunda semana de vida, quando combinada com as características morfológicas do intestino no mesmo período, sugere que larvas de pintado estão eficientemente preparadas para digerir e absorver alimentos formulados após o $13^{\circ} \mathrm{DPE}$.

3- O trato digestório das larvas de Pseudoplatystoma coruscans (pintado) está capacitado à armazenar e absorver alimentos a partir do $3^{\circ} \mathrm{DPE}$.

4- A bolsa intestinal é uma especialização do início do intestino proximal que armazena e absorve nutrientes até $16^{\circ} \mathrm{DPE}$. A função de armazenamento começa a ganha importância no estômago a partir do $13^{\circ} \mathrm{DPE}$.

5- A partir do $11^{\circ}$ DPE, o intestino distal pode ser caracterizado e diferenciado morfologicamente do intestino proximal e com funções absortivas diferenciadas em relação ao intestino proximal. 


\section{REFERÊNCIAS}

\section{AGOSTINHO, A. A. Pesquisas, monitoramento e manejo da fauna aquática em} empreendimentos hidrelétricos. In: SEMINÁRIO SOBRE FAUNA AQUÁTICA E O SETOR ELÉTRICO BRASILEIRO, 1994, Foz do Iguaçu. Rio de Janeiro: Comitê

Coordenador das Atividades de Meio Ambiente do Setor Elétrico, 1994. Caderno 1, p. 38-59.

AGOSTINHO, A. A.; JÚLIO JR., H. F.; BORGUETTI, J. R. Considerações sobre os impactos dos representantes na ictiofauna e medidas para sua atenuação. Um estudo de caso: reservatório de Itaipu. Revista Unimar, Maringá, v. 14, p. 89-107, 1992. Suplemento.

AGRAWAL, N.; MITTAL, A. K. Epithelium of lips and associated structures of the Indian Major Carp, Catla catla. Japan Journal of Ichthyology, Tokyo, v. 37, n. 4, p. 363-373, 1991.

AGRAWAL, N.; MITTAL, A. K. Structure and hitstochemistry of the epithelium of lips and associated structures of a catfish, Rita rita. Japan Journal of Ichthyology, Tokyo, v. 39, n. 1, p. 93-102, 1992.

AL-HUSSAINI, A. H. On the functional morphology of the alimentary tract of some fish in relation to difference in their feedling habits. I. Anatomy and histology. Quarterly Journal of Microscopical Science, Oxford, v. 90, p. 109-40, 1949a.

AL-HUSSAINI, A. H. On the functional morphology of the alimentary tract of some fish in relation to diferrences in their feeding habits. II. Cytology and physiology. Quarterly Journal Of Microscopical Science, Oxford, v. 90, p. 323-354, 1949b.

AL-HUSSAINI, A. H. The anatomy and histology of the alimentary tract of the botton-feeder, Mulloides auriflama. European Journal of Morphology, Lisse, v. 78, p. 121-54, 1946.

AL-HUSSAINI, A. H. The anatomy and histology of the alimentary tract of the plankton feeder Aterina forskali Rupp. European Journal of Morphology, Lisse, v. 80, p. 251-286, 1947.

ALLEN, A. Gastrointestinal mucus. In: SCHULTZ, S. G.; FORTE, J. G.; RAUMER, B. B. (Ed.). Handbook of physiology. Washington: American Physiological Society, Bethesda, 1989. sec. 6. p. 359-382.

ALLEN, A.; FLEMSTRÖM, G.; GARNER, A.; KIVILAAKSO, E. Gastroduodenal mucosal protection. Physiol., v. 73, p. 823-857, 1993. 
ALVES, C. B. M. Influência da época de enchimento na produtividade ictiofaunística em um reservatório de médio porte - UHE Cajuru, rio Pará, bacia do rio São Francisco (MG): uma proposta de manejo. 1995. 59 p. Dissertação (Mestrado em Ecologia, Conservação e Manejo de Vida Silvestre) - Instituto de Ciências Biológicas, Universidade Federal de Minas Gerais, Belo Horizonte, 1995.

ALVES, M.I.M.; TOMÉ, G. S. Anatomia e histologia do tubo digestivo da cavala Scomberomorus cavalla (Cuvier, 1829). Arquivos da Estação de Biologia Marinha da Universidade Federal do Ceara, v. 6, p. 103-108, 1966.

ANDERSON, T. A. Histological and cytological structure of the gastrointestinal tract of the luderick, Girella tricuspidata (Pisces, Kyphosidae), in relation to diet. European Journal of Morphology, Liss, v. 190, p. 109-119, 1986.

ANGELESCU, V.; GNERI, F. S. Adaptaciones del aparato digestivo al régimen alimentício in algunos peces Del rio Uruguay e Del rio de la Plata. Rev. Invest. Mus. Argent. Cienc. Nat. v. 1, n. 6, p. 161-272, 1949.

AZEVEDO, P.; GOMES, A. L. Contribuição ao estudo da biologia da traíra, Hoplias malabarica (Bloch, 1794). Boletim Industria Animal, São Paulo, v. 5, n. 4, p. 15-64, 1943.

BAGLOLE , C.J.; MURRAY, H.M.; GOFF, G.P.; WRIGHT, G.M. Ontogeny of the digestive tract during larval development of yellowtail flounder: a light microscopic and mucous histochemical study. Journal of Fish Biology, London, v. 51, p. 120-134, 1997.

BANCROFT, J. D.; GAMBLE, M. Theory and practive of histological techniques. New York: Curchill Livingstone. 2002. 796 p.

BANKS, W. J. Applied veterinary histology. St. Louis: Mosby Co., 1992. 527 p.

BARRINGTON, E.J.W. The alimentary canal and digestion in fishes. In: BROWN, M. E. (Ed.). The phisiology of fishes. New York: Academic Press, 1957. v. 1, p. 109-161.

BERTIN, L. Appareil digestif. In: GRASSÉ P. P. (Ed.). Trité de zoologie. Pria: Masson, 1958. v. 13, p. 1248-1302.

BISBAL, G. A.; BENGSTON, D. A. Development of the digestive tract in larval summer flounder. Journal of Fish Biology, London, v. 47, p. 277-291, 1995. 
BISHOP, C. M.; ODENSE, P. H. Morphology of the digestive tract of the cód, Gadus morhua. Journal of the Fisheries Research Board of Canada, Ottawa, v. 23, p. 1607$1615,1966$.

BLAKE, I. H. Studies on the comparative histology of the digestive tube of certain teleost fishes. III. A bottom-feeding fish, the sea robin Prionotus carolinus. Journal Morphology Physiology, v. 60, p. 77-102, 1936.

BLAKE, I. H. Studies on the comparative histology of the digestive tube of certain teleost fishes. I. A predaceous fish, the sea bass Centropistes striatus. Journal Morphology

Physiology, v. 50, p. 39-70, 1930.

BORGES, L. O. Contribuição ao estudo anatomo-histológico e ultra-estrutural do trato digestivo de Plecostomus commersonii (Cuvier \& Valenciennes), 1840 (Pisces). 1981. $95 \mathrm{f}$. Dissertação (Mestrado) - Universidade Federal do Paraná, Curitiba, Curitiba,1981.

BOULHIC, M.; GABAUDAN, J. Histological study of the organogenesis of the digestive system and swim bladder of the Dover sole, Solea solea (Linnaeus 1758). Aquaculture, v. 102, p. 373-396, 1992.

BRAGANÇA, M. A. L.; MENIN, E.; COSTA, I. R. S. Estudo histológico do tubo digestivo de Gymnotus garapo Linnaeus, 1758 (Siluriformes, Gymnotoidei, Gymnotidae). Revista Brasileira de Biologia, v. 52, n. 1, p. 15-25, 1992.

BRITSKI, H. A. A fauna de peixes brasileiros de água doce e o represamento de rios. In: SEMINÁRIO SOBRE FAUNA AQUÁTICA E O SETOR ELÉTRICO BRASILEIRO, 1993, Foz do Iguaçu. Rio de Janeiro: Comitê Coordenador das Atividades de Meio Ambiente do Setor Elétrico - COMASE, ELETROBRÁS, 1994. Caderno 1, p.23-30.

BRITSKI, H. A.; SATO, Y.; ROSA, A. B. S. Manual de identificação de peixes da região de Três Marias (com chaves de identificação para os peixes da Bacia do São Francisco). 3. ed. Brasília: CODEVASF, 1988. 115 p.

BUCKE, D. The anatomy and histology of the alimentary tract of the carnivorous fish, the pike Esox lucius L. Journal of Fish Biology, London, v. 3, n. 4, p. 421-431, 1971.

BURNSTOCK, G. Morphology of the gut of the brown trout Salmo trutta. Quarterly Journal of Microscopical Science, v. 100, n. 2, p. 183-198, 1959. 
CACECI, T. Scanning electron microscopy of goldfish, Carassius auratus, intestinal mucosa. Journal of Fish Biology, London, v. 25, p. 1-12, 1984.

CASTAGNOLLI, N. Criação de peixes de água doce. Jaboticabal: FUNEP, 1992. 189 p.

CATALDI, E.; CATAUDELlA, S.; MONACO, G.; ROSSI, A.; TANCIONI, L. A study of the histology and morphology of the digestive tract of the sea-bream, Spaurus aurata.

Journal of Fish Biology, London, v. 30, p. 135-145, 1987.

CAVICCHIOLI, M.; LEONHARDT, J. H. Estudo do desenvolvimento morfológico de larvas de curimbatá, Prochilodus scrofa (Steindachner, 1882), obtidas de reprodução induzida.

Revista Unimar, v. 15, p. 109-124, 1993.

CHAUDRY, H. S.; KHANDELWAL, O. P. The anatomy and histology of the alimentary tract of Oreinus plagiostomus. Annotationes Zoologicae Japonenses, v. 34, n. 3, p. 134-152, 1961.

CLARKE, A. J.; WITCOMB, D. M. A study of the histology and morphology of the digestive tract of the common eel Anguilla anguilla. Journal of Fish Biology, London, v. 16, p. 159$70,1980$.

CONNES, R.; BENHALIMA, K.; PARIS, J. Lês cellules “oxyntopeptiques" dês glandes gastriques du loup Dicentrarchus labrax (Linné, 1758) (Pisces, Serranidae). Cybium, v. 7, p. 187-92, 1983.

CORDIVIOLA, E. Nuevos aportes al conocimento de la biologia pesquera del "surubim" (Pseudoplatystoma coruscans) en el Parana médio (Pisces, Siluriformes). Physis, v. 26, p. 237-244, 1966.

CURRY, E.The histology of the alimentary canal of the carp Cyprinus carpio communis European Journal of Morphology, Lisse, v. 65, p. 53-78, 1939.

CURY, M. X. Cultivo de pintado e cachara. Panorama da Aqüicultura, p. 8-9, 1992.

CUENCA, E. M.; GALLEGO, M. G. Ingesta y conducta alimentaria. In: ESPINOSA DE LOS MONTEROS, J.; LABARTA, U. (Ed.). Nutricion em acuicultura. Madrid: Plan de Formación de Técnicos Superiores em Acuicultura, 1987. p. 1-47. 
CYRINO, J. E. P.; CARNEIRO, P. C. F.; BOZANO, G. L. N.; CASEIRO, A. C. Desenvolvimento da criação de peixes em tanques-rede. Uma análise dos fundamentos, viabilidade e tendências, baseada em experiências bem sucedidas no Sudeste do Brasil. In: AQUICULTURA BRASIL 98, 1998, Recife-PE. Anais... Recife-PE: Sociedade de Aqüicultura do Brasil, 1998. p. 409-433.

DABROWSKI, K. Ecophysiological adaptations exist in nutrient requirements of fish: true or false? Comparative Biochemistry and Physiology, New York, v. 104A, n. 3, p. 579-584, 1993.

DABROWSKI, K. The feeding of fish larvae: present state of art and perspectives. Reproduction, Nutrition, Development, v. 24, p. 807-833, 1984.

DABROWSKI, K.; CULVER, D. The physiology of larval fish. Digestive tract and formulation of starter diets. Aguac. Mag., v. 17, n. 2, p. 49-61, 1991.

DOMITROVIC, H. A.; MOREIRA, J. E. Microscopia eletrônica de varredura do trato digestivo do "sabalo" Prochilodus platensis (Holmberg 1880) Pisces, Prochilodontidae. Revista Brasileira de Ciências Morfologicas, v. 1, p. 21-30, 1984.

DOU, S.; MASUDA, R.; TANAKA, M.; TSUKAMOTO, K. Feeding resumption, morphological changes and mortality during starvation in Japanese flounder larvae Journal of Fish Biology, London, v. 60, p. 1363-1380, 2002.

ELDRIDGE, M. B.; JOSEPH, J. D.; TABERSKI, K. M.; SEABORN, G. J. Lipid and fatty acid composition of the endogenous energy source of striped bass Morone saxatilis eggs. Lipids, v. 18, p. 510-513, 1983.

EZEASOR, D. N. Light and electron microscopic studies on the oesophageal epithelium of the rainbow trout, Salmo fairdneri. Anatomischer Anzeiger, v. 155, p. 71-83, 1984.

EZEASOR, D. N. The fine structure of the gastric ephitelium of the rainbow trout, Salmo gairdneri. Journal of Fish Biology, London, v. 19, p. 611-27, 1981.

FARIAS, E. C.; INTELIZANO, W. Observações sobre o processo digestivo em peixes da familia Cichlidae. In: REUNIÃO DA SOCIEDADE BRASILEIRA PARA O PROGRESSO DA CIÊNCIA, 34, 1982, Campinas. Resumos... Campinas: UNICAMP, 1982. p. 835. 
FERRARIS, R. P.; TAN, J. D.; DE LA CRUZ, M. C. Development of the digestive tract of milkfish, Chanos chanos (Forsskal): histology and histochemistry. Aquaculture, v. 61, p. 241-257, 1987.

FERRAZ DE LIMA, J. A.; MIRANDA, M. O. T. Observações sobre as pescarias de Pirapora, rio São Francisco. Ministério da Agricultura/Superintendência do Desenvolvimento da Pesca - SUDEPE, 1987. 23 p.

FERRI, S.; HERNANDEZ-BLAZQUEZ, F.J. New observations on the membranous systems of a freshwater teleost Pimelodus maculatus oxyntic cells. Archives d'anatomie microscopique, v. 73, p. 151-158, 1984.

FISCHER, C. F. A.; CHAGAS, A. L. A.; DORNELLES, L. D. C. Pesca de águas interiores. Brasília: Instituto Brasileiro do Meio Ambiente e dos Recursos Naturais Renováveis IBAMA, 1992. 29 p. (Coleção Meio Ambiente. Série Estudos: Pesca, n.2).

FRACALOSSI, D. M. Brazilian species. In: WEBSTER, C. D. (Ed.). Nutrient requeriments and feeding of fish for aquaculture. Wallingford, UK: CABI Publishing, 2002 p. 388-395.

GALVÃO, M. S. N.; FENERICH-VERANI, N.; YAMANAKA, N.; OLIVEIRA, I. R. Histologia do sistema digestório da tainha Mugil platanus (Günther, 1880) (Osteichthyes, Mugilidae) durante as fases larval e juvenil. B. Inst. Pesca. v. 24, p. 91-100, 1997.

GARGIULO, A. M.; CECCARELLI, P.; DALL AGLIO, C.; PEDINI, V. Histology and ultrastructure of the gut of the tilapia Tilapia spp., a hybrid teleost. Archives D' Anatomie, D' Histologie Et D' Embryologie Normales Et Experimentales, Colmar, v. 27, n. 2, p. 8994, 1998.

GAS, N.; NOAILLAC-DEPEYRE, J. Different cells in the stomach epithelium of Ameirus nebulosus involved in gastric juice product. Biologie Cellulaire, Paris, v. 31, p. 181-190, 1978.

GAUTHIER, G. F.; LANDIS, S. C. The relationship of ultrastructural and cytochimical features to absorptive activity in the goldfihs intestine. The Anatomical Record, Massachusetts, v. 172, p. 675-702, 1972.

GEIGER, J. G. A review of pond zooplâncton production and fertilization for the culture of larval and fingerling striped bass. Aquaculture, v. 35, n. 4, p. 353-359, 1983. 
GEISER, J. G.; TURNER, C. J.; FITZMAYER, K. Feeding habits of larval and fingerling striped bass and zooplankton dynamics in fertilized rearing ponds. The Progressive FishCulturist, v. 47, n. 4, p.213-223, 1985.

GISBERT, E.; RODRIGUEZ, A.; CASTELLÓ-ORVAY, F.; WILLIOT, P. A histological study of the development of the digestive tract of Siberian sturgeon (Acipenser baeri) during early ontogeny. Aquaculture, v. 167, p. 195-209, 1998.

GODINHO, H. P.; GODINHO, A. L. Ecology and conservation of fish in southeastern Brazilian river basins submitted to hydroelectric impoundments. Acqua Limnologica Brasiliensia, v. 5, p. 187-197, 1994.

GODINHO, H. P.; MIRANDA, M. O. T.; GODINHO, A. L.; SANTOS, J. E. Pesca e biologia do surubim Pseudoplatystoma coruscans no rio São Francisco em Pirapora, $M G$. In: REUNIÃO DO GRUPO DE AVALIAÇÃO TÉCNICA DE SILURIFORMES DO BRASIL, 1, 1990, Pirassununga, SP: Centro de Pesquisa e Treinamento em Aqüicultura CEPTA/IBAMA. 1990, p. (Datil).

GODINHO, H.; TOKUMARU, M.; FERRI, A.G. Histologia do trato digestivo de Pimelodus maculatus Lacépède, 1803 (Pisces, Siluroidei). Revista Brasileira de Biologia, v. 30, p. 583593, 1970.

GODOY, M. P. Rio Iguaçu, Paraná, Brasil. Reconhecimento da ictiofauna, modificações ambientais e usos múltiplos de reservatórios. Florianópolis: Centrais Elétricas do Sul do Brasil S.A. 1979. 33 p.

GOHAR, H. A. F.; LATIF, A .F. A. The histology of the alimentary tract in resentative scarid and labrid fishes. Publ. Mar. Bio. Stn. Al- Ghardaqa, v. 11, p. 95-126, 1960.

GOMES, R. M. Estudo morfológico e histoquímico (carbohidratos) do trato digestivo de Rhamdia branneri, Hasemman, 1911 (Pices). 1981. 87 f. Dissertação (Mestrado) Universidade Federal do Paraná, Curitiba, 1981.

GONZALEZ DE CANALES, M.; SARASQUETE, M.C.; GUTIERREZ, M. Estudio histoenzimologico de fosfatasas en aparato digestivo de Mugil auratus (Risso) (Osteichtyes, Mugilidae). Boletim de Fisiologia Animal. Universidade de Sao Paulo, v. 11, p. 101-111, 1987.

GORDON, A. K.; HECHT, T. Histological studies on the development of the digestive system of the clownfish Amphiprion percula and the time of weaning. Journal of Applied Ichthyology, Berlin, v. 18, p. 113-117, 2002. 
GOULDING, M. The fishes and the Forest: exploration in Amazonian Natural History. Berkeley: University of California Press. 1980. 280 p.

GOVONI, J. J.; BOEHLERT, G. W.; WATANABE, Y. The physiology of digestion in fish larvae. Env. Biol. Fish. v. 16, p. 59-77. 1986.

GRAU, A.; CRESPO, S; SARASQUETE, M. C.; GONZÁLEZ DE CANALES, M. L. The digestive tract of the amberjack Seriola dumerih, Risso: a light and scanning microscopic study. Journal of Fish Biology, v.41, p. 287-303, 1992.

GRIZZLE, J. M.; CURD, M. R. Posthatching histological development of the digestive system and swim bladder of logperch, Percina caprodes. Copeia, v. 3, p. 448-455, 1978.

GUPTA, O. P. Studies on the morphology, histology and the swallowing mechanism of the digestive tract of a carnivorous fish, Xenentodon cancila (Ham.). Okajimas Folia Anatomica Japonica, v. 48, n.1, p. 29-51, 1971.

HERNANDEZ-BLAZQUEZ, F. J. Estudo microscópico (óptico e eletrônico) e hisitoquímica do esôfago e estômago cárdico de Prochilodus escrofa. (Steindachner, 1881). 1986. 192 p. Dissertação (Mestrado). Instituto de Ciências Biomédicas - Universidade de São Paulo. São Paulo

HERNANDEZ-BLAZQUEZ, F. J.; SILVA, J. R. M. C. Absorption of macromolecular proteins by the rectal epithelium of the antartic fish Notothenia neglecta. Canidiam Journal Zoology, v. 76, p. 247-253, 1998.

HILSDORF, A.W.S.; MOREIRA, R. G. Aqüicultura. Scientific American. São Paulo, ano 2, n. 22, p. 24-29, 2004.

IRO, S. Anatomic structure of the gastric mucosa. In: CODE, C.F. (Ed.) Handbook of physiology, Washington-D.C.: Am. Physiol. Soc., 1967. v. 2, p.705-741.

IWAI, T. Fine structure of gut epithelium cells of larval and juvenile carp during absorption of fat and protein. Archivum histologicum Japonicum, v. 30, p. 183-189, 1969.

JIRGE, S. K. Mucopolysaccharide histochemistry of the stomach of fishes with different food habits. Folia Histochemica Et Cytochemica, v. 8 p. 275-80, 1970. 
KAPOOR, B.G.; EVANS, H.E.; PEVENER, R.A. The gustatory system in fish. Advances in Marine Biology, v. 13, p. 53-108, 1975a.

KAPOOR, B.G.; SMIT, H.; VERIGHINA, I.A. The alimentary canal and digestion in teleosts. Advances in Marine Biology, v. 13, p. 109-239, $1975 \mathrm{~b}$.

KHANNA, S.S.; MEHROTA, B.K. Morfology and histology of the teleostean intestine. Anat. Anz. Bd., n. 129S, p. 1-18, 1971.

KUBITZA, F. Preparo de rações e estratégias de alimentação no cultivo intensivo de peixes carnívoros. In: SIMPÓSIO INTERNACIONAL SOBRE NUTRIÇÃO DE PEIXES E CRUSTÁCEOS. 1995, Campos do Jordão, Anais... Campos do Jordão: Colégio Brasileiro de Nutrição Animal, 1995. p. 91-115.

KUCHINSKI, F. B. Anatomia, histologia e histoquímica do estômago de Colossoma mitrei, Ber, 1895 (Pacu-caranha) nos estágios alevino jovem, peixe jovem e adulto. 1985. 114f. Tese (Doutorado da Universidade Mackenzie). São Paulo. 1985.

LAUDER, G. V.; LIEM, K. F. The evolution and interrelationships of the Actinopterygian fishes. Bulletin of the Museum of Comparative Zoology, v. 150, n. 3, p. 95-197, 1983.

LING, E. A.; TAN, C. K. Fine structure of the gastric epithelium of the coral fish, Chelmon rostratus Cuvier. Okajimas Folia Anatomica Japonica, Tokyo, v. 51, n. 6, p.285-310, 1975.

LOEWE, H. E.; ECKMANN, R. The ontogeny of the alimentary tract of coregonid larvae: normal development. Journal of Fish Biology, London, v. 33, p. 841-850, 1988.

LOGATO, P. V. R. Anátomo-histologia do aparelho digestivo do pacu, Piaracatus mesopotamicus Holmberg, 1887 (Characiformes, Characidae, Myelinae). 1995. 119 f. Dissertação (Mestrado em Zootecnia) - Universidade Federal de Viçosa, Viçosa, Minas Gerais. 1995.

LOPES, M. C.; FREIRE, R. A. B.; VICENSOTTO, J. R. M.; SENHORINI, J. A. Alimentação de larvas de surubim pintado, Pseudoplatystoma coruscans (Agassiz, 1892) em laboratório na primeira semana de vida. Boletim Técnico Cepta. n.9, p. 11-29, 1996.

MACDONALD, N. L. An electron microscopic examination of the gastrointestinal epithelium of the gastrointestinal epithelium in dover sole, Solea solea (L.). Journal of Fish Biology, London, v. 31, p. 27-36, 1987. 
MARQUES, E. E. Biologia reprodutiva, alimentação natural e dinâmica da nutrição do pintado Pseudoplatystoma coruscans (Agassiz, 1929) (Osteichthyesm, Pimelodidae) no alto rio Paraná. 1993. 104 f. Dissertação (Mestrado em Ciências Biológicas) - Universidade Federal do Paraná, Curitiba, Paraná. 1993.

MARTIM, T. J.; BLABER, S. J. M. Morphology and histology of the alimentary tract of Ambassidae (Cuvier) Teleostei in relation to feeding. European Journal of Morphology, Lisse, v. 182, p. 295-305, 1984.

MARTINO, R. C.; CYRINO, J. E. P.; PORTZ, L.; TRUGO, L. C. Effects of dietary lipid level on nutritional performance of the surubim, Pseudoplatysmtoma coruscans.

Aquaculture, v. 209, p. 209-218, 2002.

MEDEIROS, L. O.; FERRI, S.; FERRI, A. G.; BARCELOS, S. R. Estudo histoquímico de polissacarídeos do tecido epitelial do tubo digestivo de Pimelodus maculatus. Revista Brasileira de Biologia. v. 30, p. 81-85, 1970a.

MEDEIROS, L.O.; FERRI, S.; LONGHI, L.; WORSMANN, T.U. Histochemical study of protein in epithelial tissue of the digestive tract of Pimelodus maculates. Acta

Histochemistry, v. 37, p. 113-117, 1970 b.

MENANDRO, L. E. Proposta de política para o trato da fauna aquática no setor elétrico. In: SEMINÁRIO SOBRE FAUNA AQUÁTICA E O SETOR BRASILEIRO 1993. Curitiba. [Anais...]. Rio de Janeiro: Comitê Coordenador das Atividades de Meio Ambiente do Setor Elétrico - COMASE, ELETROBRÁS, 1994. cad. 3, p. 30-38.

MENEZES, N. A. Importância da conservação da ictiofauna dos ecossistemas aquáticos brasileiros. In: SEMINÁRIO SOBRE FAUNA AQUÁTICA E O SETOR BRASILEIRO 1993. Curitiba. [Anais...]. Rio de Janeiro: Comitê Coordenador das Atividades de Meio Ambiente do Setor Elétrico - COMASE, ELETROBRÁS, 1994. cad. 3, p. 7-13.

MENEZES, R. S. Pesca e piscicultura no vale do São Francisco. Boletim da Secretaria da Agricultura , Indústria e Comércio do Estado de Pernambuco, v. 23, n. 314, p.43-105, 1956.

MENIN, E.; MIMURA, O. M. Anatomia funcional da cavidade bucofaringeana de rochilodus marggravii (Wallbaum, 1792) e Prochilodus affinis Reinhardt, 1874 (Characiformes, Prochilodontidae). Revista Ceres, v. 39, p. 506-527, 1992. 
MENIN, E. Anátomo-histologia functional comparativa do aparelho digestivo de seis Teleostei (Pisces) de água doce. 1988. 557 f. Tese (Doutorado em Fisiologia) - Universidade de São Paulo, São Paulo. 1988.

MIRANDA, M. O. T. Características zootécnicas e rendimento de carcaça do surubim Pseudoplatystoma coruscans do Rio São Francisco. 1993. 50 f. Dissertação (Mestrado em Zootecnia, Área de Produção Animal) - Universidade Federal Minas Geral, Belo Horizonte. 1993.

MIRANDA, M. O. T.; RIBEIRO, L. P.; ARANTES, F. S.; SIQUEIRA, A. M.; DINIZ, M. G. Diagnóstico do setor pesqueiro no estado de Minas Gerais. Belo Horizonte: Superintendência do Desenvolvimento da Pesca - SUDEPE/Coordenadoria Regional de Minas Gerais, 1988. 30p. (Relatório, Datil.).

MOHSIN, S. M. Comparative morphology and histology of the alimentary canals in certain groups of indian teleosts. Acta Zoologica, v. 43, p.79-133, 1962.

MOHSIN, S. M. The morphology and histology of the alimentary canal of Glossogobius giuris (Ham.). Canadian Journal of Zoology, v. 39, p. 605-613, 1961.

MORAES, M. F. P. G.; BARBOLA, I. F.; GUEDES, E. A. C. Alimentação e relações morfológicas com o aparelho digestivo do "curimbatá", Prochilodus lineatus (Valenciennes) (Osteichthyes, Prochilodontidae), de uma lagoa do sul do Brasil. Revista Brasileira de Zoologia, v. 14, n. 1, p. 169-180, 1997.

MOTA AVES, M. I. Sobre o trato digestivo da serra, Scomberomorus maculatus (Mitchill). Arquivos de Ciencias do Mar, v. 9, n. 2, p. 167-171, 1969.

MOTA AVES, M. I.; TOMÉ, G. de S. Anatomia e histologia do tubo digestivo de Scomberomorus cavalla (Cuvier, 1829). Arquivos da estação de Biologia Marinha da Universidade Federal do Ceará, v. 6, n. 2, p. 103-108, 1966.

MURRAY, H. M.; WRIGTH, G. M.; GOFF, G. P. A comparative histological and histochemical study of the stomach from three species of pleuronectid, the Atlantic halibut, Hippoglossus hippoglossus, the yellowtail flounder, Pleuronectes ferruginea, and the winder flounder, Pleuronectes americanus. Canadian Journal of Zoology, v. 72, p. 1199-1210, 1994a.

MURRAY, H. M.; WRIGTH, G. M.; GOFF, G. P. A study of the posterior oesophagus in the winter flounder, Pleuronectes americanus, and the yellowtail flounder, Pleuronectes ferruginea: morphological evidence for pregastric digestion. Canadian Journal of Zoology, Ottawa, v. 72, p. 1191-1198, 1994b. 
NACHI, A. M. Intestino de Prochilodus serofa (Curimbata): estudo histológico, histoquímico de glicoconjugados e da absorção de lipídeos utilizando diferentes métodos de inclução.1988. 106 f. Dissertação (Mestrado) - Instituto de Ciências Biomédicas, Universidade de São Paulo, São Paulo,1988.

NEVES, C. A. Estudo morfológico e histoenzimológico do desenvolvimento ontogenético do trato digestivo de larvas e alevinos de trairão (Hoplias eflacerdae) e de pacamã (Lophiosilurus alexandri). 1996. 74 f. Dissertação (Mestrado em Morfologia) - Universidade Federal de Minas Gerais, Belo Horizonte, 1996.

NEVES. C. A.; GODINHO, H. P. Desenvolvimento ontogenético do trato digestivo do trairão (Hoplias lacerdae). In: ENCONTRO ANUAL DA ASSOCIAÇÃO MINEIRA DE AQÜICULTURA E SEMINARIO DA BACIA DO RIO GRANDE, 1995, Passos. Resumos... [Passaos]: Furnas, Associação Mineira de Aqüicultura, 1995. 69 p.

NIKOLSKY, G. V. The Ecology of Fishes, London: Academic Press., 1963. 325 p.

NOAILLAC-DEPEYRE, J.; GAS, N. Structure and function of intestinal epithelial cells in the perch (Perca fluviatus L. ). Anatomical Record, v. 195, p. 621-40, 1979.

NOAILLAC-DEPEYRE, J.; GAS, N. Ultrastructural and cytochemical study of the gastric epithelium in a fresh water teleostean fish (Perca fluvialitis). Cell and Tissue Research, v. 10, n. 1, p. 23-37, 1978.

OGURI, M. A histological study on the endocrine and exocrine glands of fish by Bowie's stain. Bulletin of the Japanese Society of Scientific Fisheries, v. 45, p. 823-827, 1979.

OLIVEIRA, I. R; SOARES, L. S. H. Alimentação de tainha Mugil platanus (Günther, 1880) Pisces: Mugilidae, da região estuarina-lagunar de Cananéia. Boletim do Instituto de Pesca, v. 23, p.95-104, 1996.

OPUSZYNSKI, K.; SHIREMAN, J. V. Food passage time and daily ration of bighead carp. Aristichthys nobilis, kept in cages. Environmental biology of fishes, n. 30, p. 387-393, 1991.

OSMAN, A. H. K.; CACECI, T. Histology of the stomach of Tilapia nilotica (Linnaeus, 1758) from the River Nile. Journal of Fish Biology, v. 38, p. 211-223, 1991.

PAIVA, M. P. Grandes represas do Brasil. Brasília: Editerra Editorial Ltda. 1982a. 304 p. 
PAIVA, M. P.; BASTOS, S. A. Marcações de peixes nas regiões do Alto e Médio São Francisco (Brasil). Ciência e Cultura, v. 34, n. 10, p. 1362-1362, 1982 b.

PASHA, S. M. K. Anatomy and histology of the alimentary canal of a herbivorous fish Tilapia mossambica (Peters). Proceedings of the Indiana Academy of Science, n. 59B, p. 340-349, 1964.

PEÑA, R.; DUMAS, S.; VILLALEJO-FUERTE, M.; ORTÍZ-GALINDO, J. J. Ontogenic development of the digestive tract in reared spotted sand bass Paralabrax maculatofasciatus larvae. Aquaculture, 219, p. 633-644, 2003.

PETRERE JR., M. Synthesis on fisheries in large tropical reservoirs in South America - In: SIMPÓSIO REGIONAL SOBRE MANEJO DE LA PESCA EN EMBALSES EN AMERICA LATINA, Habana, Cuba, 1994. p. 83.

PETRINI, L. M. Sobre a presença de capilares intra-epiteliais na mucosa do estômago do cascudo (Plecostomus plecostomus Linneu). Ciência e Cultura, v. 13, p. 175, 1961.

PINTO-COELHO, R. M.; GIANNI, A.; VON SPERLING, E. (Ed.). Ecology and human impact on lakes and reservoirs in Minas Gerais, with special reference to future development and management strategies. Belo Horizonte: SEGRAC, 1994.

PINTO, M. G.; CASTAGNOLLI, N. Desenvolvimento inicial do pacu, Colossoma mitrei (Berg, 1895). In: SIMPÓSIO BRASILEIRO SOBRE AQÜICULTURA, 1984. São Carlos. Anais... Ministério da Agricultura e SUDEPE. v. 3, 1984. p. 523-535.

PREJS, A. Metodos para el estúdio de los alimentos y lãs relaciones troficas de los peces. Caracas: Universidad Central de Venezuela y Universidad de Varsóvia, 1981. 129 p.

RABELLO, T. Empresa reproduz pintado em cativeiro. Criação de pintado irá preservar a espécie. O Estado de São Paulo. São Paulo, 08 de julho de 1992. n. 1913. Ano XXXVII, Suplemento Agrícola, p. 10-11.

RAUTHER, M. Die akzessorischen atmung sorgane der knochenfische. Ergebn. Fortschr. Zool., v. 2, p. 517-535, 1910.

REID, S. B. La biologia de los bagres rayados Pseudoplatystoma fasciatum e $P$. Tigrinum en la cuenca del rio Apure. Venezuela. Revista Unellez de Ciencia y Tecnología. v. 1, n.1, p. 13-41, 1983. (Serie: Producción Agrícola. Barinas). 
REIFEL, C. W. Endocrine cells in the gastrointestinal tract of a stomachless teleostean fish. Anatomischer Anzeiger, v. 167, p. 259-263, 1988.

REIFEL, C. W.; TRAVILL, A. A. Structure and carbohydrate histochemistry of the intestine in ten teleostean. European Journal of Morphology, Lisse, v. 162, p.343-60, 1979.

REIFEL, C. W.; TRAVILL, A. A. Structure and carbohydrate histochemistry of the esophagus in ten teleostean species. European Journal of Morphology, v. 152, n. 3, p. 303314, 1977.

REIFEL, C. W.; TRAVILL, A. A. Gross morphology of the alimentary canal in 10 teleostean species. Anatomischer Anzeiger, v. 144, p. 441-449, 1978a.

. Structure and carbohydrate histochemistry of the stomach in eight species of teleosts. Journal Morphological, v. 158, p. 156-66, 1978 b.

RIBEIRO, L.; SARASQUETE, M. C.; DINIS, M. T. Histological and histochemical development of the digestive system of Solea senegalensis (Kaup, 1858) larvae.

Aquaculture, v. 171, p. 293-308, 1999.

ROS, A. E.; DELFINO, R. Las pesquerias de la cuenca Del Plata em bolívia, Paraguay, Argentina y Uruguay (Estudo Analisado). In: SIMPOSIO INTERNACIONAL SOBRE ASPECTOS AMBIENTAIS DA BACIA DO PRATA, 1993, Foz do Iguaçu. [Anais...]. Rio de Janeiro: Instituto Acqua., 1994. p. 187-200. (Série Bacia do Prata, n. 1)

SANTOS, E. Peixes de água doce (Vida e costumes dos peixes do Brasil). Belo Horizonte: Ed. Itatiaia, 1981. 267 p. (Coleção Zoologia Brasílica, v.2).

SANTOS, J. E.; GODINHO, H. P. Larval morphogenesis and behaviour of the surubim Pseudoplatystoma coruscans (Agassiz 1829) under experimental conditions. Arquivos Brasileiro de Medicina Veterinária e Zootecnia, v. 46, n. 2, p. 139-147, 1994.

SANTOS, M. T. M.; MENDES FILHO, A.; NEPOMUCENO, H. Estudos histoquímicos do tubo digestivo de Plagioscion equamosissimus (Heckel, 1840). Revista de Médicina da Universidade Federal do Ceará, v. 19, p. 19-25, 1979.

SARASQUETE, M. C.; POLO, A; YÚFERA, M. Histology and histochemistry of the development of the digestive system of larval gilthead seabream, Sparus aurata L.

Aquaculture, v. 130, p. 79-92, 1995. 
SARBAHI, D. S. Studies of the digestive tracts and the digestive enzymes of the goldfish, Carassus auratus and the largemouth black bass, Micropterus salmoides (Lac.). Biological Bulletin, v. 100, p. 244-257, 1951.

SATO, Y. Estação de hidrobiologia e Piscicultura de Três Marias da CODEVASF. In: SEMINÁRIO SOBRE FAUNA AQUÁTICA E O SETOR ELÉTRICO BRASILEIRO (Reuniões Temáticas Preparatórias), 1994. Piraí, RJ. [Anais...]. Rio de Janeiro: Comitê Coordenador das Atividades de Meio Ambiente do Setor Elétrico - COMASE, ELETROBRÁS, 1995. cad. 5, p. 18-22.

SATO, Y.; AMORIM, J. C. C.; CARDOSO, E. L. Aproveitamento das lagoas marginais a montante da barragem de Três Marias/MG (II. Resultados Preliminares). In: ENCONTRO ANUAL DE AQUICULTURA DE MINAS GERAIS, 2., 1983, Belo Horizonte. Resumos... Brasília: CODEVASF, 1988a. p.46-47.

SATO, Y.; CARDOSO, E. L.; SALLUM, W. B. Reprodução induzida do surubim (Pseudoplatystoma coruscans) da bacia do São Francisco. In: ENCONTRO ANUAL DE AQUICULTURA, 6., 1988, Belo Horizonte, MG. Resumos... Belo Horizonte: Associação Mineira de Aqüicultura - AMA, 1988b. p. 20.

SATO, Y.; OSÓRIO, F. M. F. A pesca profissional na região de Três Marias, em 1986. In: ENCONTRO ANUAL DE AQUICULTURA DE MINAS GERAIS, 5., 1987. Belo Horizonte. Coletânea de Resumos... Brasília: CODEVASF, 1988c p. 91-92.

SATO, Y.; CARDOSO, E. L.; AMORIM, J. C. C. Peixes das lagoas marginais do rio São Francisco a montante da represa de Três Marias, MG. Brasília: CODEVASF, 1987. 42 p.

SATO, Y.; CARDOSO, E. L.; SALLUM, W. B.; GODINHO, H.P Indução experimental da desova do surubim Pseudoplatystoma coruscans. In: MIRANDA, M. O. T. (Org.) Surubim. Belo Horizonte-MG: IBAMA, 1997.p. 69-80 (Coleção Meio Ambiente, Série Estudos Pesca, 19).

SEGNER, H.; RÖSCH, R.; VERRETH, J.; WITT, U. Larval nutritional physiology studies with Clarias gariepinus, Coregonus lavaretus and Scophthalmus maximus. Journal of the World Aquaculture Society, v. 24, p. 121-134, 1993.

SINHA, G. M. Scanning electron microscopic study of the intestinal mucosa of an Indian freshwater adult major carp, Labeo rohita (Hamilton). Jahrbuch fur Morphologie Und Mikroskopische Anatomie, v. 97, p. 979-92, 1983. 
SINHA, G. M.; MOITRA, S. K. Functional morpho-histology of the alimentary canal of na indian freshwater major carp, Labeo rohita (Hamilton) during it's different life-history stages. Anatomischer Anzeiger, v. 138, p. 222-239, 1975a.

SINHA, G. M.; MOITRA, S. K. Morpho-histology of the intestine in a freshwater major carp, Cirrhinus mrigala (Hamilton) during the different life-history stages in relation to food and feeding habits. Anatomischer Anzeiger, v. 137, p. 395-407, 1975 b.

SIRE, M. F.; VERNIER, J. M. Intestinal absorption of protein in teleost fish. Comparative Biochemistry and Physiology, v. 4, n. 103A, p. 771-81, 1992.

SIS, R. F.; IVES, P. J.; JONES, D. M.; LEWIS, D. H.; HAENSLY, W. E. The microscopic anatomy of the oesophagus, stomach and intestine of the channed catfish, Ictalurus punctatus. Journal of Fish Biology, v. 14, p. 179-86, 1979.

SOARES, T. R. S. Estudo morfológico do tubo digestivo do pintado, Pseudoplatystoma coruscans, empregando-se métodos histológicos, histoquímicos e microscopia eletrônica de varredura. 1993. 118 f. Dissertação (Mestrado) - Instituto de Ciências Biomédicas, Universidade de São Paulo, São Paulo,1993.

SORGELOOS, P.; LEGER, P. Improved larviculture outputs of marine fish, shrimp and prawn. World Aquaculture Society, v. 23, n. 4, p. 251-337, 1992.

SOUSA, A. B. Estudo citogenético em Pseudoplatystoma coruscans (Pisces, Pimelodidae) das bacias do rio Paraguai e rio São Francisco. 1993. 75 f. Dissertação (Mestrado em Zootecnia) - Universidade Federal de Minas Gerais, Belo Horizonte,1993.

SOUSA, A. B.; FONSECA, C. G.; PINHEIRO, L. E. L.; RIBEIRO, L. P. Análise cromossômica de Pseudoplatystoma coruscans (Teleostei, Pimelodidae) das bacias dos rios São Francisco e Paraguai. In: ENCONTRO ANUAL DE AQUICULTIRA, 11., 1994. Belo Horizonte, MG. Resumos... Belo Horizonte: Associação Mineira de Aqüicultura, 1994. p. 30.

SOUZA, S. N. Avaliação da estrutura do aparelho digestório de alevinos de surubim, Pseudoplatystoma coruscans, Agassiz, 1829 (SILURIFORMES, SILUROIDEI, PIMELODIDAE) relacionado com sua capacidade de selecionar e digerir o alimento. 1999. 95 f. Dissertação (Mestrado) - Universidade de Viçosa, Viçosa, 1999.

STROBAND, H. W. J.; DABROWSKI, K. R. Morphological and physiological aspects of the digestive system and feeding in freshwater fish larvae. In: . La nutrition des poissons: actes du coloque. C.N.E.R.N.A., 1979. Paris: Publiés sous la direction de M. Fontaine; CNRS, 1979. 
STROBAND, H. W. J.; KROON, A. G. The development of the stomach in Clarias lazera and the intestinal absorption of protein macromolecules. Cell and Tissue Research, v. 215, p. 397-415, 1981a.

STROBAND, H. W. J.; VAN DER VEEN, F .H. Localization of protein absorption during transport of food in the intestine of grasscarp Ctenopharyngodon idella. Journal of Experimental Zoology, v. 218, p. 149-156, 1981 b.

SUYEHIRO, Y. A study of the digestive system and feeding habits of fish. Japanese Journal of Zoology, v. 10, p. 301-303, 1942.

TAN, C. K.; TEH, Y. F. The structure of the gut of a coral fish Chelmon rostratus Cuv. Okajimas Folia Anatomica Japonica, v. 51, p. 63-80, 1974.

TOLEDO, L. R. Novo hóspede dos açudes. Globo Rural, Editora Globo, v. 6, n. 68. p. 5461,1991 .

TORLONI, C. E. C. Manejo dos recursos pesqueiros nos reservatórios da CESP. In: SEMINÁRIO SOBRE FAUNA AQUÁTICA E O SETOR ELÉTRICO BRASILEIRO, 1994, Piraí, RJ. [Anais...] Rio de Janeiro: Comitê Coordenador das Atividades de Meio Ambiente, 1995. cad. 5, p. 58-68.

TREVISAN, P. Histomorphological and histochemical researches on the digestive tract of the freshwater grass carp, Ctenopharyngodon idella (Cypriniformes). Anatomischer Anzeiger, v. 145, p. 237-248, 1979.

VASQUES, L. H.; SANTOS, H. S. L.; NAKAGHI, L. S. O.; SOUZA, V. L.; ZAIDEN, S. F. Aspectos estruturais e ultraestruturais do esôfago da "piracanjuba", Brycon orbignyanus (Valenciennes, 1849) ( Pisces, Characidae). In: AQUICULTURA BRASIL, 98., 1998, Recife. Resumos... Recife: Sociedade de Aqüicultura do Brasil, 1998. p. 225.

VERIGINA, I. A. Structure of the digestive tract of the lake sevan khramulya (Cyprinidae), Varicorhinus, capoeta sevangi (F.). Journal of Ichthyology, v. 9, p. 428-433, 1969.

VERRETH, J. A. J.; TORREELE, E.; SPAZIER, E.; SLUISZEN, V.D.; ROMBOUT, J. H. W. M.; BOOMS, R.; WALFORD, J.; LAM, T. J. Development of digestive tract and proteolytic enzyme activity in seabass (Lates calcarifer) larvae and juveniles. Aquaculture, v. 109, p. 187-205, 1993. 
VU, TAN TUE. Étude histologique de lépithélium du tube digestif du Bar, Dicentrarchus labrax ( $L$ ), au cours du développement post - embryonnaire. Arch. Zool. Exp.Géh., v. 121, n.3, p. 191-200, 1980.

WALFORD, J.; LAM, T. J. Development of digestive tract and proteolytic enzyme activity in seabass ( Lates calcarifer) larvae and juveniles. Aquaculture, v. 109, p. 187-205, 1993.

WATANABE Y. An ultrastructural study of intracellular digestion of horseradish peroxidase by the rectal epithelium cells in larvae of a feshwater cottid fish Cottus nozawae. Bulletin of the Japanese Society of Scientific Fisheries, v. 50, p. 409-416, 1984.

WATANABE Y. Ingestion of horseradish peroxidase by the intestinal cells in larvae or juveniles of some teleosts. Bulletin of the Japanese Society of Scientific Fisheries, v. 47, p. 1299-1307, 1981.

WEATERLEY,A. H.; GILL, S. H. The biology of fish growth. London: Academic Press, 1987. $443 \mathrm{p}$.

WEINREB, E. L.; BILSTALD, N. M. Histology of the digestive tract and adjacent structures of the rainbow trout Salmo gairdneri irideus. Copeia v. 3, p. 194-204, 1955.

WELCOMME, R. L. River fisheries. Roma: Food and Agriculture Organization of the United Nations - FAO, 1985. 330 p. (FAO Fisheries Technical Papers. 262).

WELCOMME, R. L. Ordencion de la explotacion pesquera en los grandes rios. Roma: FAO, 1980. 65 p. (Doc. Téc. Pesca 194),

WESTERN, J. R. H.; JENNINGS, J. B. Histochemical demonstration of hydrochloric acid in the gastric tubules of teleosts using an in vivo. Prussian blue techinique. Comparative Biochemistry and Physiology, v. 35, p. 879-884, 1970.

WESTERN, J. R. H.; JENNINGS, J. B. Studies on the diet, feeding mechanism and alimentary tract in two closely related teleosts, the freshwater Cottus gobio, L. and the marine Parenophrys bubalis, Euphrasen. Acta Zoologica, v. 50, p. 185-205, 1969.

ZAMITH, A. P. L. Contribuição para o conhecimento da estrutura da mucosa do esôfago dos vertebrados. Anais da Escola Superior de Agricultura Luiz de Queiroz, v. 9, p. 357-434, 1952. 
ZIMMERMANN, S.; JOST, H. C. Recentes avanços na nutrição de peixes: a nutrição por fases em piscicultura intensiva. In: SIMPÓSIO SOBRE MANEJO E NUTRIÇÃO DE

PEIXES, 2., 1998, Piracicaba. Anais... Piracicaba: Colégio Brasileiro de Nutrição Animal, 1998. p. 123-162. 